Prepared in cooperation with the City of Palo Alto, California

Near-Field Receiving-Water Monitoring of Trace Metals and a Benthic Community Near the Palo Alto Regional Water Quality Control Plant in South San Francisco Bay, California-2019

Open-File Report 2021-1079

U.S. Department of the Interior U.S. Geological Survey 
Cover. Palo Alto mudflat at sunrise. Photograph by Francis Parchaso, U.S. Geological Survey, September 26, 2008. 


\section{Near-Field Receiving-Water Monitoring of Trace Metals and a Benthic Community Near the Palo Alto Regional Water Quality Control Plant in South San Francisco Bay, California-2019}

By Daniel J. Cain, Marie-Noële Croteau, Janet K. Thompson, Francis Parchaso, Robin Stewart, Kelly H. Shrader, Emily L. Zierdt Smith, and Samuel N. Luoma

Prepared in cooperation with the City of Palo Alto, California

Open-File Report 2021-1079 


\section{U.S. Geological Survey, Reston, Virginia: 2021}

For more information on the USGS - the Federal source for science about the Earth, its natural and living resources, natural hazards, and the environment-visit https://www.usgs.gov or call 1-888-ASK-USGS.

For an overview of USGS information products, including maps, imagery, and publications, visit https://store.usgs.gov.

Any use of trade, firm, or product names is for descriptive purposes only and does not imply endorsement by the U.S. Government.

Although this information product, for the most part, is in the public domain, it also may contain copyrighted materials as noted in the text. Permission to reproduce copyrighted items must be secured from the copyright owner.

Suggested citation:

Cain, D.J., Croteau, M.-N., Thompson, J.K., Parchaso, F., Stewart, R., Shrader, K.H., Zierdt Smith, E.L., and Luoma, S.N., 2021, Near-field receiving-water monitoring of trace metals and a benthic community near the Palo Alto Regional Water Quality Control Plant in south San Francisco Bay, California-2019: U.S. Geological Survey Open-File Report 2021-1079, 59 p., https://doi.org/10.3133/ofr20211079.

Associated data for this publication:

Cain, D.J., Croteau, M.N., Parchaso, F., Stewart, R., Thompson, J.K., Zierdt Smith, E.L., Kieu, L., Turner, M., and Baesman, S.M., 2021, Data for monitoring trace metal and benthic community near the Palo Alto Regional Water Quality Control Plant in south San Francisco Bay, California: U.S. Geological Survey data release, https://doi.org/10.5066/P9IBQ23S.

ISSN 2331-1258 (online) 


\section{Acknowledgments}

Le Kieu and Mark Marvin-DiPasquale, both U.S. Geological Survey, provided the mercury data. Histological samples were prepared by Central Histology Facility, in Sacramento, Calif.

\section{Contents}

Acknowledgments .............................................................................................................................ii

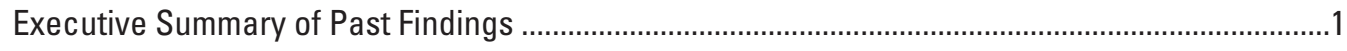

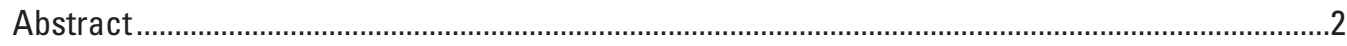

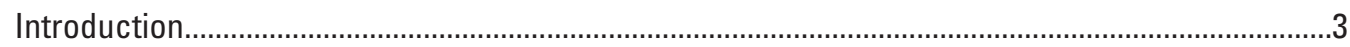

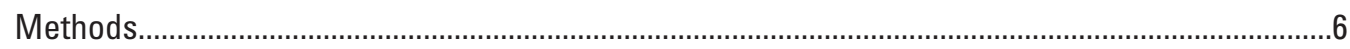

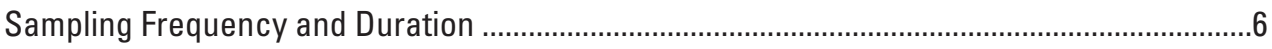

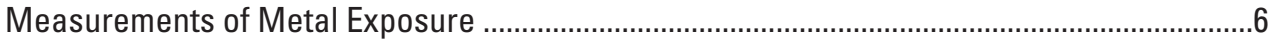

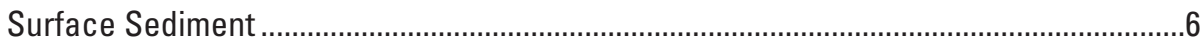

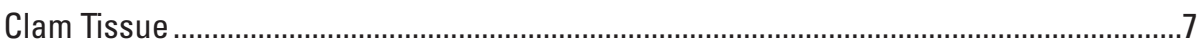

Sample Preparation for Metal Analysis, Excluding Mercury and Selenium ............................7

Analytical, Excluding Mercury and Selenium ......................................................................

Sample Preparation and Analysis for Mercury and Selenium.................................................

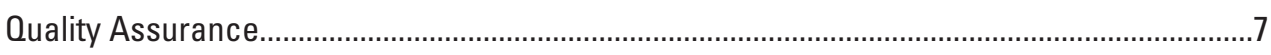

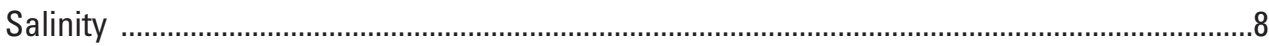

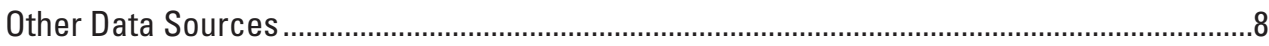

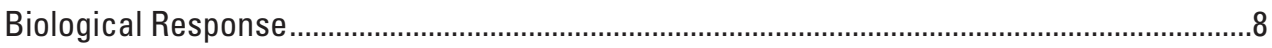

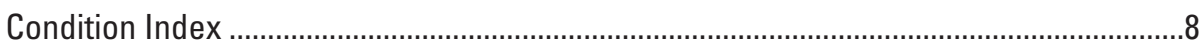

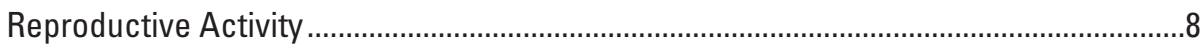

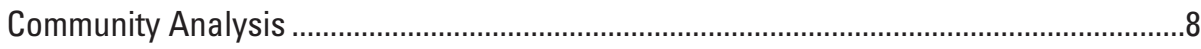

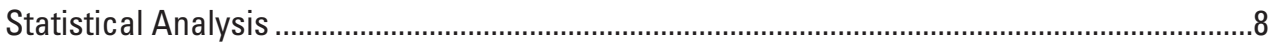

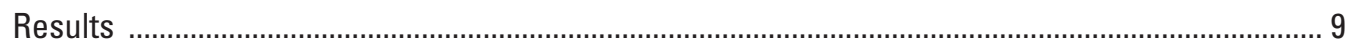

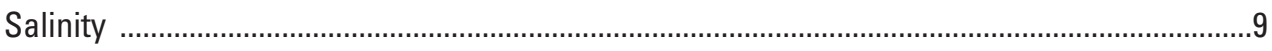

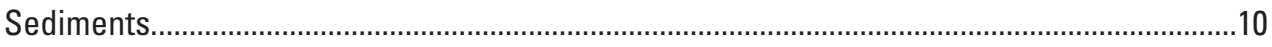

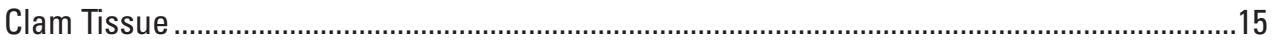

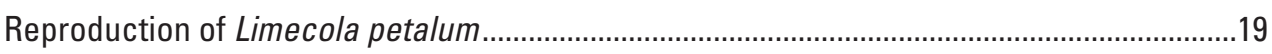

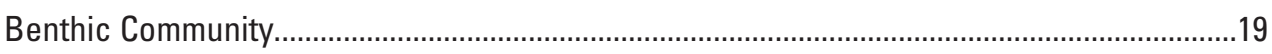

Summary

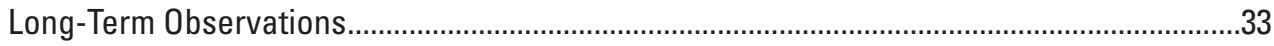

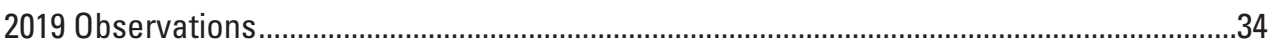

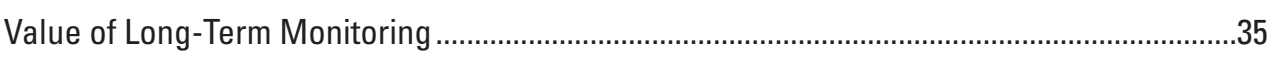

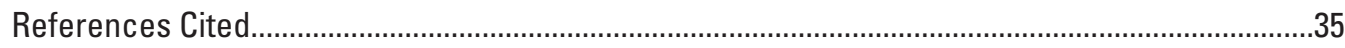

Appendix 1. Certified Concentrations and Recovery Percentages of Inorganic Elements in National Institute of Science and Technology Standard Reference Materials 2709a and 2711a, Prepared in 2019... 
Appendix 2. Certified Concentrations and Recovery Percentages of Inorganic Elements in National Research Council Canada Certified Reference Material TORT-3 and National Institute of Science and Technology Standard Reference Material 1566b, Prepared in 2019.

Appendix 3. Mercury and Selenium Concentrations Determined in Sample Splits of Surface Sediments and Clam Limecola petalum Collected at Palo Alto, Calif., Site in 2019 ...

Appendix 4. Recovery Percentages ( \pm Standard Deviation) of Mercury and Selenium in Standard Reference Materials

Appendix 5. Method Detection Limits and Method Reporting Levels for Inductively Coupled Plasma Optical Emission Spectrophotometry Methods

Appendix 6. Statistical Summary of Silver and Copper Concentrations in Sediment and Clam Limecola petalum Collected at Palo Alto, Calif., Site in 2019 and in 1977-2019 .45

Appendix 7. Reproduction Data for Clam Limecola petalum Collected at Palo Alto, Calif.,

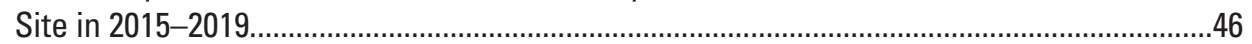

Appendix 8. Complete List of Benthic Species Found at Palo Alto, Calif., Site in 2019.................48

Appendix 9. Benthic Species Name Changes as of 2019 ….....................................................56

\section{Figures}

1. Location of Palo Alto sampling sites in south San Francisco Bay, Calif.

2. Graphs showing precipitation recorded at station San Francisco WB AP, San Mateo County, Calif. .99

3. Surface-water salinity at Palo Alto, Calif., site, 1994-2019. 10

4. Plots showing concentrations of metals and total organic carbon in sediments at Palo Alto, Calif., site, 2015-2019.

5. Plot showing general seasonal variations in aluminum, iron, and percentage of fine sediments at Palo Alto, Calif., site.

6. Plots showing annual concentrations of metals and total organic carbon in sediments at Palo Alto, Calif., site...

7. Plots showing metal concentrations in soft tissues of clam Limecola petalum at Palo Alto, Calif., site, 2015-2019

8. Plots showing condition index of clam Limecola petalum at Palo Alto, Calif., site .........17

9. Plots showing metal concentrations in clam Limecola petalum at Palo Alto, Calif., site

10. Reproductive activity of clam Limecola petalum at Palo Alto, Calif., site, 1974-2019.....19

11. Reproductive activity of clam Limecola petalum at Palo Alto, Calif., site, 2015-2019.....19

12. Plots showing total number of species present at Palo Alto, Calif., sampling site .........20

13. Plots showing total average number of individuals present at Palo Alto, Calif., sampling site.

14. Plots showing monthly average abundances of Limecola petalum at Palo Alto, Calif., sampling site.

15. Plots showing monthly average abundances of Mya arenaria at Palo Alto, Calif., sampling site. 
16. Plots showing monthly average abundances of Gemma gemma at Palo Alto, Calif., sampling site..

17. Plots showing monthly average abundances of Ampelisca abdita at Palo Alto, Calif., sampling site...

18. Plots showing monthly average abundances of Streblospio benedicti at Palo Alto, Calif., sampling site.

19. Plots showing monthly average abundances of Grandidierella japonica at Palo Alto, Calif., sampling site

20. Plots showing monthly average abundances of Alitta succinea at Palo Alto, Calif., sampling site

21. Plots showing monthly average abundances of Heteromastus filiformis at Palo Alto, Calif., sampling site

22. Plots showing monthly average abundances of Nippoleucon hinumensis at Palo Alto, Calif., sampling site

23. Graphs showing reproductive-mode annual abundances for top-10-ranked species, as well as silver concentrations in clam Limecola petalum and in sediment, at Palo Alto, Calif., site, 1974-2019

24. Graphs showing reproductive-mode annual abundances for top-10-ranked species, as well as copper concentrations in clam Limecola petalum and in sediment, at Palo Alto, Calif., site, 1974-2019

25. Graphs showing feeding-mode annual abundances for top-10-ranked species, as well as silver concentrations in clam Limecola petalum and in sediment, at Palo Alto, Calif., site, 1974-2019

26. Graphs showing feeding-mode annual abundances for top-10-ranked species, as well as copper concentrations in clam Limecola petalum and in sediment, at Palo Alto, Calif., site, 1974-2019

27. Plots showing species rank-abundances for benthic community at Palo Alto, Calif., site, 2016-2019

28. Plots showing species rank-abundances for benthic community at Palo Alto, Calif., site, for years 1977, 1989, 2002, and 2019

29. Plots showing rank-abundances identified by feeding modes of same benthic-community species shown in figure 28 , at Palo Alto, Calif., site, for years 1977, 1989, 2002, and 2019.

30. Plots showing rank-abundances identified by reproductive modes of same benthic-community species shown in figure 28 , at Palo Alto, Calif., site, for years 1977, 1989, 2002, and 2019 


\section{Tables}

1. Concentrations of fine particles in surface sediments and major and minor inorganic elements for samples collected from the Palo Alto, Calif., site, 2019...........14

2. Concentrations of trace metals in, and condition index of, clam Limecola petalum at the Palo Alto, Calif., site, 2019

1.1. Certified concentrations and recovery percentages of inorganic elements in National Institute of Science and Technology standard reference materials 2709a and 2711a, prepared in 2019

2.1. Certified concentrations and recovery percentages of inorganic elements in National Research Council Canada certified reference material TORT-3 and National Institute of Science and Technology standard reference material 1566 b, prepared in 2019 ..

3.1. Mercury and selenium concentrations determined in sample splits of surface sediments and clam Limecola petalum collected at Palo Alto, Calif., site in 2019.......42

4.1. Recovery percentages ( \pm standard deviation) of mercury and selenium in standard reference materials

5.1. Method detection limits and method reporting levels for inductively coupled plasma optical emission spectrophotometry methods

6.1. Statistical summary of silver and copper concentrations in sediment and clam Limecola petalum collected at Palo Alto, Calif., site in 2019 and in 1977-2019 45

7.1. Reproduction data for clam Limecola petalum collected at Palo Alto, Calif., site in 2015-2019...

8.1. Complete list of benthic species found at Palo Alto, Calif., site in 2019........................49

9.1. Benthic species name changes as of $2019 .$. 


\section{Conversion Factors}

International System of Units to U.S. customary units

\begin{tabular}{|c|c|c|}
\hline Multiply & By & To obtain \\
\hline \multicolumn{3}{|c|}{ Length } \\
\hline centimeter $(\mathrm{cm})$ & 0.3937 & inch (in.) \\
\hline millimeter (mm) & 0.03937 & inch (in.) \\
\hline meter $(\mathrm{m})$ & 3.281 & foot (ft) \\
\hline kilometer $(\mathrm{km})$ & 0.6214 & mile (mi) \\
\hline \multicolumn{3}{|c|}{ Area } \\
\hline square meter $\left(\mathrm{m}^{2}\right)$ & 10.76 & square foot $\left(\mathrm{ft}^{2}\right)$ \\
\hline \multicolumn{3}{|c|}{ Volume } \\
\hline liter (L) & 33.81402 & ounce, fluid (fl. oz) \\
\hline liter (L) & 0.2642 & gallon (gal) \\
\hline liter (L) & 61.02 & cubic inch $\left(\right.$ in $\left.^{3}\right)$ \\
\hline \multicolumn{3}{|c|}{ Mass } \\
\hline gram (g) & 0.03527 & ounce, avoirdupois (oz) \\
\hline
\end{tabular}

Temperature in degrees Celsius $\left({ }^{\circ} \mathrm{C}\right)$ may be converted to degrees Fahrenheit $\left({ }^{\circ} \mathrm{F}\right)$ as

$$
{ }^{\circ} \mathrm{F}=\left(1.8 \times{ }^{\circ} \mathrm{C}\right)+32 .
$$

Temperature in degrees Fahrenheit $\left({ }^{\circ} \mathrm{F}\right)$ may be converted to degrees Celsius $\left({ }^{\circ} \mathrm{C}\right)$ as

$$
{ }^{\circ} \mathrm{C}=\left({ }^{\circ} \mathrm{F}-32\right) / 1.8 \text {. }
$$

\section{Abbreviations}
$\mu \mathrm{g} / \mathrm{g}$
microgram per gram
$\mu \mathrm{m}$
micrometer
$\%$
parts per thousand
ANOVA
analysis of variance
$\mathrm{Cl}$
condition index
conf. int.
confidence interval
CV
coefficient of variation
EPA
U.S. Environmental Protection Agency
ERL
effects range low
ERM
effects range median
$\mathrm{HCl}$
hydrochloric acid
HG-ICP-MS
hydride generation inductively coupled plasma mass spectrometry
ICP-OES
inductively coupled plasma optical emission spectrophotometry 


\begin{tabular}{|c|c|}
\hline $\mathrm{M} \Omega-\mathrm{cm}$ & megohm centimeter \\
\hline MDL & method detection limit \\
\hline $\mathrm{mg}$ & milligram \\
\hline $\mathrm{mg} / \mathrm{kg}$ & milligram per kilogram \\
\hline $\mathrm{mL}$ & milliliter \\
\hline MLLW & mean lower low water \\
\hline MRL & method reporting level \\
\hline $\mathrm{N}$ & normal \\
\hline NIST & National Institute of Standards and Technology \\
\hline NPDES & National Pollutant Discharge Elimination System \\
\hline NRCC & National Research Council Canada \\
\hline PARWOCP & Palo Alto Regional Water Quality Control Plant \\
\hline PC & personal computer \\
\hline ppm & parts per million \\
\hline RWOCB & California Regional Water Quality Control Board \\
\hline SD & standard deviation \\
\hline SEM & standard error of the mean \\
\hline SRM & standard reference material \\
\hline TMDL & total maximum daily loading \\
\hline TOC & total organic carbon \\
\hline UC & University of California \\
\hline USGS & U.S. Geological Survey \\
\hline
\end{tabular}




\title{
Near-Field Receiving-Water Monitoring of Trace Metals and a Benthic Community Near the Palo Alto Regional Water Quality Control Plant in South San Francisco Bay, California-2019
}

\author{
By Daniel J. Cain, Marie-Noële Croteau, Janet K. Thompson, Francis Parchaso, Robin Stewart, Kelly H. \\ Shrader, Emily L. Zierdt Smith, and Samuel N. Luoma
}

\section{Executive Summary of Past Findings}

U.S. Geological Survey (USGS) personnel have assessed trace-metal concentrations in sediments and sedimentdwelling species at an intertidal site in the vicinity of the discharge of the Palo Alto Regional Water Quality Control Plant (PARWQCP) since 1977. They have also profiled that area's benthic community structure and analyzed factors that could affect benthic community structure, including exotic species invasions, pelagic food availability, and weather anomalies, since 1974. Collectively, this dataset describes a long-term, detailed history of metal concentrations and benthic community dynamics at this site.

Initial studies during the 1970s and early 1980s found exceptionally high concentrations of silver (Ag) and copper $(\mathrm{Cu})$ in mud-dwelling animals in this area (Luoma and Cloern, 1982; Luoma and others, 1985). Additional studies identified the PARWQCP as a point source for silver and copper and established the clam Limecola petalum (synonymous name, Macoma petalum) as a biological indicator of metal exposure (Thomson and others, 1984). Elevated metal concentrations coincided with reduced reproductive activity in L. petalum (Hornberger and others, 2000). Related studies (Hook and Fisher, 2001, 2002) supported the interpretation that elevated metal concentrations inhibited reproduction. The benthic community also showed signs of environmental stress. Opportunistic organisms (capable of fast invasion and propagation in disturbed environments) dominated the community. These organisms thrived on the surface of the mud in tubes or as shelled animals, brooded their young, and fed on waterborne particles.

Concentrations of silver and copper in both sediments and tissues of $L$. petalum declined significantly during the 1980s as the PARWQCP implemented more advanced wastewater treatment and source control programs. Copper concentrations in sediments and tissues of L. petalum exhibited downward trends that correlated with reduced copper discharge from the PARWQCP (Hornberger and others, 2000; data for silver loading were not available before 1989). Coincident with the decline in copper and silver in the sediment and clams, the reproductive activity of the clam increased. The composition of the benthic community also shifted during this period. Opportunistic species became less dominant, and less opportunistic species became more persistent. Other environmental factors that vary seasonally and annually (for example, sediment composition, grain-size distribution, organic content, and ambient water salinity) were not associated with the observed temporal trends in metal concentrations, inferred metal effects on species, and benthic community changes. The only unidirectional change in an environmental factor during this period (1980-1990) was the decline in metal concentrations in discharge from the wastewater treatment plant (Hornberger and others, 2000). The temporal coincidence between metals discharge from the plant, metal concentrations in sediment and tissues of L. petalum at the site, and the observed biological responses suggested that the recession in metal exposure was principally responsible for the observed biological recovery.

After the significant reductions in the 1980s, concentrations of silver and copper in sediments and $L$ petalum continued to decline, although much more gradually. Silver concentration of sediment remains greater than what is considered the natural regional background $(0.09 \pm 0.02$ milligrams per kilogram $[\mathrm{mg} / \mathrm{kg}])$ (Hornberger and others, 1999). The concentrations of silver and copper in L. petalum have fluctuated as much as four-fold since the 1994. Some of the interannual variation in silver concentrations of $L$. petalum appears related to annual growth and reproductive cycles independently of exposure. Copper concentrations did not appear responsive to either modest changes in sedimentary copper or growth and reproductive cycles.

Biological responses coincident with the decline and stabilization of silver and copper exposures were evident. 
Reproductive activity of $L$. petalum increased (Hornberger and others, 2000). Structural and functional attributes of the benthic community shifted from an assemblage of taxa dominated by a few surface-dwelling, brooding species to species with various life-history characteristics. In particular, species that lay their eggs in the mud and feed by burrowing through and consuming the mud, which were rare in the community in the 1970s and 1980s, have increased in abundance. Today, the community at this site is very similar to the benthic community observed by Thompson and Parchaso (2012) throughout south San Francisco Bay.

When the trace metal study started in the late 1970s, the site was already heavily contaminated. Although we assume that the biological conditions reflected the consequences of elevated metal exposures, there is a scarcity of preexisting data to evaluate the effects of elevated metal exposure, particularly over decadal time scales. However, the long-term record collected in this study provides a unique opportunity to document biological response when the stress of metal exposure is relaxed. The data - together with complementary studies - make a compelling case that the mitigation of silver and copper in wastewater effluent during the 1980s allowed for biological recovery and the establishment of a more diverse and stable infaunal community.

\section{Abstract}

Trace-metal concentrations in sediment and in the clam Limecola petalum (World Register of Marine Species, 2020; formerly reported as Macoma balthica and M. petalum), clam reproductive activity, and benthic macroinvertebrate community structure were investigated in a mudflat 1 kilometer south of the discharge of the Palo Alto Regional Water Quality Control Plant (PARWQCP) in south San Francisco Bay, Calif. This report includes the data collected by the U.S. Geological Survey (USGS) for the period January 2019 to December 2019 (Cain and others, 2021). These data append to long-term datasets extending back to 1974. A major focus of the report is an integrated description of the 2019 data within the context of the longer, multidecadal dataset. This dataset supports the City of Palo Alto's Near-Field ReceivingWater Monitoring Program, initiated in 1994.

Significant reductions in silver and copper contamination occurred at the site in the 1980s following the implementation by PARWQCP of advanced wastewater treatment and source control measures. Since the 1990s, concentrations of these elements in surface sediments have continued to decrease, although more slowly. Silver appears to have stabilized at concentrations somewhat above the regional background concentration. For example, during the period 1994-2019, the minimum silver concentration - 0.20 milligrams per kilogram $(\mathrm{mg} / \mathrm{kg})$ observed in multiple years since 2008 , including 2019 - is approximately twice the regional background concentration. Presently, sediment copper concentrations appear to be near the regional background level. Over the same period (1994-2019), sedimentary iron and zinc also exhibited modest declines. Sedimentary aluminum, chromium, mercury, nickel, and selenium have not exhibited any trend. Since 1994, concentrations of silver and copper in L. petalum have varied seasonally, apparently in response to a combination of site-specific metal exposures and cyclic growth and reproduction, as reported previously. Seasonal patterns for other elements, including chromium, mercury, nickel, selenium, and zinc, were generally similar in timing and magnitude as those for silver and copper. The annual growth and reproductive cycle explained a small amount of the variance in annual silver and zinc tissue metal concentrations. However, interannual trends are not apparent for any element.

Biological effects of elevated silver and copper contamination at the Palo Alto site have been interpreted from data collected during and after the recession of these contaminants. Concentrations of both elements in the soft tissues of $L$. petalum declined with sedimentary copper and silver. This pattern was associated with changes in the reproductive activity of $L$. petalum, as well as the structure of the benthic invertebrate community. Reproductive activity of L. petalum increased as metal concentrations in L. petalum declined (Hornberger and others, 2000) and presently is stable with almost all animals initiating reproduction in the fall and spawning the following spring. Analyses of the benthic community structure indicate that the infaunal invertebrate community has shifted from one dominated by several opportunistic species when silver and copper exposures were highest to one in which the species abundance is more evenly distributed, a pattern that indicates a more stable community that is subjected to fewer stressors. Importantly, this long-term change is unrelated to other metals and other measured environmental factors, including salinity and sediment composition. In addition, two of the opportunistic species (Ampelisca abdita and Streblospio benedicti) that brood their young and live on the surface of the sediment in tubes have shown a continual decline in dominance coincident with the decline in metals. Both species had short-lived rebounds in abundance in 2008, 2009, and 2010 and showed signs of increasing abundance in 2019. Heteromastus filiformis (a subsurface polychaete worm that lives in the sediment, consumes sediment and organic particles residing in the sediment, and reproduces by laying its eggs on or in the sediment) showed a concurrent increase in dominance and, in the last several years before 2008, showed a stable population. H. filiformis abundance increased slightly in 2011-2012 and returned to pre-2011 numbers in 2019.

An unidentified disturbance occurred on the mudflat in early 2008 that resulted in the loss of the benthic animals, except for deep-dwelling animals like L. petalum. However, within two months of this event, animals returned to the mudflat. The resilience of the community suggested that the disturbance was not caused by a persistent toxin or anoxia. The reproductive mode of most species that were present in 2019 was indicative of species that were available either 
as pelagic larvae or as mobile adults. Although oviparous species were lower in number in this group, the authors hypothesize that these species will return slowly as more species move back into the area. The use of functional ecology was highlighted in the 2019 benthic community data, which showed that the animals that have now returned to the mudflat are those that can respond successfully to a physical, nontoxic disturbance. Today, community data show a mix of species that consume the sediment, or filter feed, those that have pelagic larvae that must survive landing on the sediment, and those that brood their young. USGS scientists view the 2008 disturbance event as a response by the infaunal community to an episodic natural stressor (possibly sediment accretion or a pulse of freshwater), in contrast to the long-term recovery from metal contamination. We will compare this recovery to the long-term recovery observed after the 1970s when the decline in sediment pollutants was the dominating factor.

\section{Introduction}

Determining spatial distributions and temporal trends in trace metals in sediments and benthic organisms is common practice for monitoring environmental contamination. These data can be the basis for assessing metal exposure, the potential for adverse biological effects, and the response to regulatory or management actions (Suter, 2001). Another common method of environmental monitoring is to examine the community structure of sediment-dwelling benthic organisms (Simon, 2002). Spatial and temporal changes in community structure reflect the integrated response of resident species to environmental conditions, although the underlying cause(s) for the response may be difficult to identify and quantify. Together, measurements of metal exposure and biological response can provide a more complete view of anthropogenic disturbances and the associated effects on ecosystem health.

Sediment particles can strongly bind metals, effectively repartitioning them from solution to a solid phase. As a result, sediments may accumulate and retain metals released to an aquatic environment. Sediment cores provide a historical record of metal inputs that can reveal anthropogenic influences (Förstner and Wittmann, 1979). Specifically, studies of sediment cores in San Francisco Bay chronicled metal inputs and suggested that legacy contamination can remain a chronic source of metals to the system owing to sediment mixing and redistribution (Hornberger and others, 1999; van Geen and Luoma, 1999). Metals in sediments also indicate exposure levels to benthic animals through contact with, and ingestion of, bottom sediments and suspended particulate materials. However, physical and geochemical conditions of the sediment affect the biological availability of the bound metals. Assimilation of bioavailable sediment-bound metal by digestive processes and the contribution of this source of metals relative to metals in the aqueous phase are difficult to predict from sediment concentrations alone. Thus, in order to better estimate bioavailable metal exposures, the tissues of the organisms themselves may be analyzed for trace metals (Phillips and Rainbow, 1993). Different species concentrate metals to different degrees. However, if one species is analyzed consistently, the results can be used to track temporal changes in trace-element exposures at a specified location.

Contaminants can adversely affect benthic organisms at several organizational levels. For example, responses to a pollutant at the cellular or physiological level of an individual can cause changes at the population level, such as reductions in growth, survival, and reproductive success (Newman, 1998). Community-level responses to population-level impairment can include overall shifts in diversity and species abundance, favoring metal-tolerant species, which can result in changes in predator-prey interactions and competition for available resources. Changes in the benthic community can ultimately result in changes at the ecosystem level because of that community's importance as primary consumers in the cycling of carbon in aquatic environments (Alpine and Cloern [1992] provided a local example).

In all aquatic environments, benthic organisms may be exposed to contaminants at all life stages through a variety of routes - sediment, water, and food (Wang and Fisher [1999] provided a summary of the potential transport of trace elements through food). Toxicant exposure is related to contaminant concentration and time (frequency and duration of exposure). Even at fairly low contaminant levels, longterm exposure can affect benthic organisms (Long and others, 1995). The added complexity of synergistic or antagonistic effects between different contaminants, and between contaminants and natural stressors, makes causal relationships difficult to identify and quantify, even on a site-specific basis. However, a time-integrated picture of ecosystem response to contaminant loading can be provided by field studies that link changes in exposure at multiple time scales (in this case, seasonal to decadal) to changes at individual, population, and community levels. Data from such studies support surveillance and compliance of water-quality objectives.

Permits issued by the California Regional Water Quality Control Board (RWQCB) under the National Pollutant Discharge Elimination System (NPDES) to the Palo Alto Regional Water Quality Control Plant (PARWQCP) (fig. 1) require a prescribed self-monitoring program. In addition, the City of Palo Alto augments its own monitoring program with data collected by the U.S. Geological Survey (USGS). The USGS monitoring protocols have been designed to be compatible with or complementary to the RWQCB's Regional Monitoring Program. In this report, the USGS monitoring study is described, and data collected during 2019 are presented within the context of more than 43 years of previous data collections and investigations by the USGS at this intertidal location.

The data collected during this study include trace-metal concentrations in sediments and clams, clam reproductive activity, and benthic community structure (based on taxonomic 


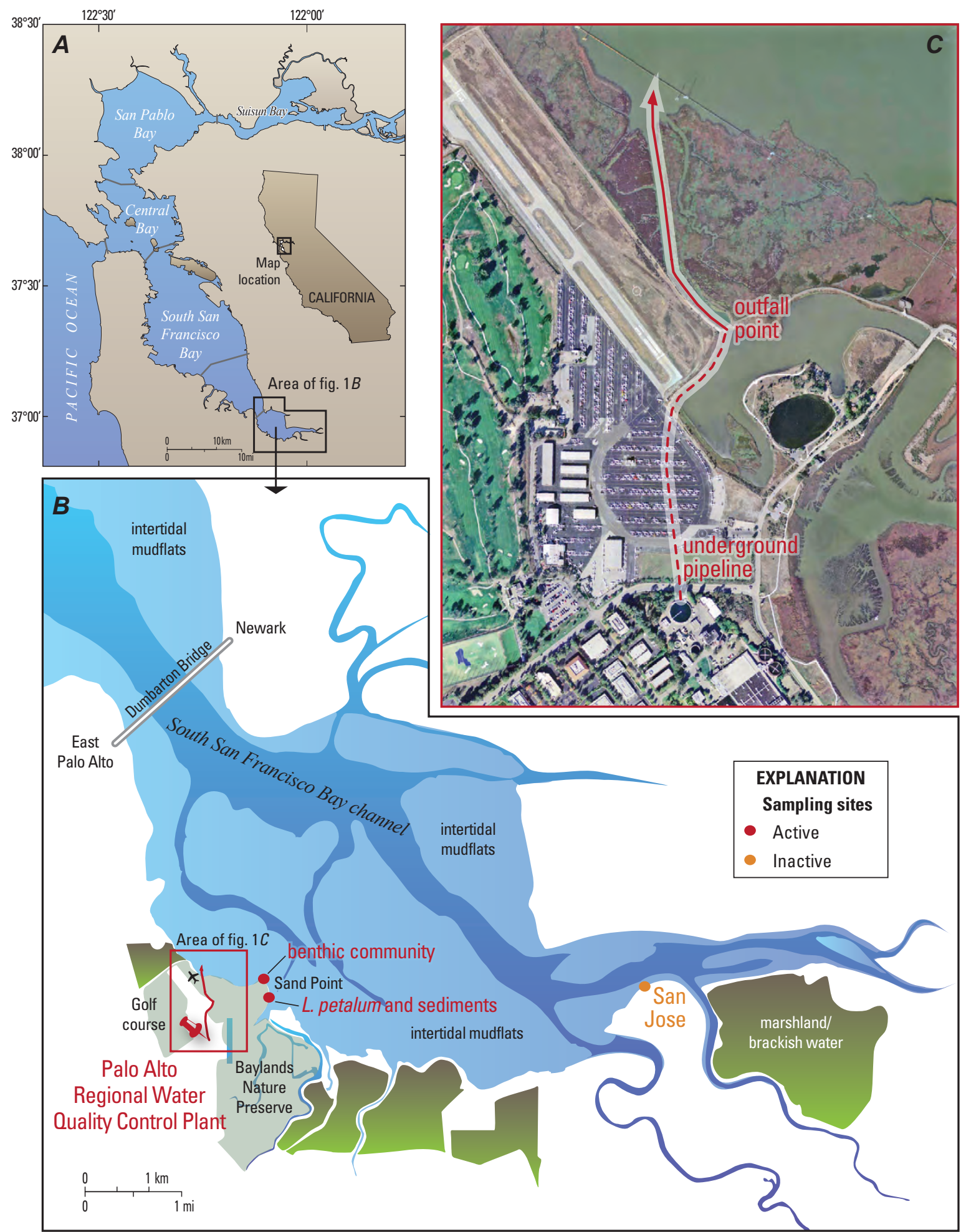

Figure 1. Location of Palo Alto sampling sites in south San Francisco Bay, Calif. $A$, Map showing location of sampling areas (and fig. $1 B$ ) within greater San Francisco Bay region. B, Map showing Palo Alto sampling sites (red dots), which consist of benthic community at Sand Point and clam Limecola petalum and sediments localities a few hundred meters south of it; inactive San Jose sampling site (orange dot) shown for reference. Red box shows Palo Alto Regional Water Quality Control Plant (located at red thumbtack) and surrounding area (and fig. $1 C$ ). Intertidal mudflats are shaded lighter blue; subtidal areas, darker blue; marshland-brackish water areas, green-brown; and recreational areas, gray. $C$, Image showing Palo Alto Regional Water Quality Control Plant (red thumbtack in $B$ ). Effluent from plant is discharged by way of underground pipe (dashed red line) until it reaches the outfall point at the mouth of small channel, which flows (red arrow) through intertidal mudflat to the bay, about 1 kilometer west-northwest of the sampling sites. 
analyses). These data and those reported earlier (for example, Luoma and others, 1991, 1995a, 1996; Hornberger and others, 2000; Thompson and others, 2002; Shouse and others, 2003, 2004; Moon and others, 2005; Cain and others, 2006; Dyke and others, 2012, 2014) were used to meet the following objectives:

- Provide data to assess seasonal and annual trends in trace-element concentrations in sediments and clams, reproductive activity of clams, and benthic community structure at a site designated in the RWQCB's self-monitoring program guidelines for PARWQCP.

- Present the data within the context of historical changes in south San Francisco Bay and within the context of other locations in the bay published in the international literature.

- Coordinate an inshore receiving-water monitoring program for PARWQCP and provide data compatible with relevant aspects of the regional monitoring program. The near-field data will augment the regional monitoring program as suggested by the RWQCB.

- Provide data that could support other south San Francisco Bay management issues or programs, such as total maximum daily loading (TMDL) targets.

Despite the complexities inherent in monitoring natural systems, the adopted approach has been effective in relating changes in near-field contamination to changes in reproductive activity of a clam (Hornberger and others, 2000) and in benthic community structure (Kennish, 1998). This study, with its basis in historical data, provides a rare multidecadal context within which future environmental changes can be assessed.

Metal concentrations were monitored in sediments and a resident clam species, Limecola petalum. Analysis of tracemetal concentrations in the sediments over time provides a record of metal contamination of the site. The concentration and bioavailability of sediment-bound metals are affected by physical and geochemical factors (Thomson-Becker and Luoma, 1985; Luoma and others, 1995b). Thus, ancillary data, including grain-size distribution, organic carbon, aluminum and iron content of the sediment, regional rainfall, and surface salinity were collected to interpret seasonal, annual, and interannual variation in metal concentrations. The tissue of L. petalum provides an estimate of internalized metal (dose), an indication of exposure to bioavailable metals. Although the measured metal concentrations are specific to L. petalum, they serve as a relative indicator of metal exposure to the broader benthic invertebrate community.

Biological response of the benthic community to metal exposure was examined at three levels of organization: individual, population, and community. At the individual level, concentrations of metals in the tissues of L. petalum were compared with physiological indicators. Two common animal responses to environmental stress are reductions in both growth and reproductive activity. Growth and reproduction in L. petalum occur on fairly regular seasonal cycles. Seasonally, a clam of a given shell length will increase somatic tissue weight as it grows during the late winter and spring (Cain and Luoma, 1990). Reproductive tissue increases during the early stages of reproduction and declines during and after spawning. These cycles can be followed with the condition index (CI), which is represented as the total soft-tissue weight of a clam standardized to shell length and is indicative of the physiological condition of the animal (Cain and Luoma, 1990). Interannual differences in growth and reproduction, expressed in the CI, are affected by the availability and quality of food, as well as other stressors, such as pollutant exposure and salinity extremes. Hornberger and others (2000) showed that reproductive activity of $L$. petalum increased with declining metal concentrations in animals from this location. Therefore, CI and reproductive activity of $L$. petalum appear to be useful indicators of physiological stress by pollutants at this location, and they continue to be monitored in this study.

At the population level, trends of the dominant benthic species were examined to see if certain species have been more affected than others by environmental change. It has been shown that most taxonomic groups have species that are sensitive to elevated silver (Luoma and others, 1995b) and that some crustacean and polychaete species are particularly sensitive to elevated sedimentary copper (Rygg, 1985; Morrisey and others, 1996). In addition, the benthic community was examined for changes in structure - that is, shifts in the species composition of the macroinvertebrate community that typically result in a change in the function of that community. The authors hypothesized that a shift in community composition and potentially in the function of the benthic community in the ecosystem would result from changes in the concentrations of either specific metals or a combination of contaminants for several reasons. First, prior studies have shown that south San Francisco Bay benthic communities were dominated by opportunistic species in the 1980s (Nichols and Thompson, 1985a). These opportunistic species might become less dominant as environmental stressors decrease. Second, environmental pollutants may differentially affect benthic species that use different feeding and reproductive modes. An intertidal mudflat community, such as this study site, should include a combination of species that feed on particles in the water column, on settled and buried food particles in the mud, and on other organisms. The absence of any one of these feeding groups may impose limitations on species as a result of environmental stressors that target specific feeding groups. For example, pollutants attached to sediment particles are more likely to affect species that consume the sediment as part of their feeding mode or those species that lay their eggs in the sediment.

Previous analysis of this community has shown no correlation between changes in the community and measured environmental parameters (salinity, air and water temperature, delta outflow, precipitation, chlorophyll a, sediment total organic carbon, and biological oxygen demand; Shouse, 2002). Therefore, the community data are compared only to trace-metal data in this report. 
The Palo Alto site, which is located on a mudflat on the western shore of San Francisco Bay (fig. 1), includes the benthic community sampling site at Sand Point, in Baylands Nature Preserve, and the L. petalum and sediment sampling site a few hundred meters south of it. The site is 1 kilometer $(\mathrm{km})$ southeast of the intertidal discharge point of the PARWQCP. The sampling locations are approximately 12 meters $(\mathrm{m})$ from the edge of the marsh and 110 centimeters $(\mathrm{cm})$ above mean lower low water (MLLW).

The sediment and biological samples from this location reflect a response of the receiving waters to the effluent just beyond the location of discharge. Earlier studies (Thomson and others, 1984) showed that dyes, natural organic materials in San Francisquito Creek, and waters in the PARWQCP discharge move predominantly east-southeastward toward Sand Point, thereby affecting the mudflats in the vicinity of Sand Point. Thomson and others (1984) showed that San Francisquito Creek and the nearby Palo Alto Yacht Harbor were minor sources of most trace elements compared to the PARWQCP. Based on spatial and temporal trends of copper, silver, and zinc in clams and sediments, the PARWQCP appeared to be the primary source of elevated metal concentrations at the Palo Alto site in the spring of 1980 (Thomson and others, 1984; Cain and Luoma, 1990). Metal concentrations in sediments and clams (L. petalum), especially silver and copper, have declined substantially since the original studies as more efficient treatment processes and source controls were employed (Hornberger and others, 2000). Significant seasonal variability required frequent sampling each year to characterize temporal trends (Luoma and others, 1985; Cain and Luoma, 1990). This report characterizes data for the year 2019, thereby extending the long-term record at this site.

\section{Methods}

\section{Sampling Frequency and Duration}

In dynamic ecosystems such as San Francisco Bay, the environmental effects of anthropogenic stressors are difficult to distinguish from natural seasonal or life-cycle changes. Sustained sampling at frequent intervals can characterize seasonal patterns, capture episodic events, and identify longer term trends, thereby increasing the probability that anthropogenic effects can be identified. Analyses of early community data (1974-1983; Nichols and Thompson, 1985a, b) showed that benthic samples need to be collected at monthly to bimonthly intervals to distinguish between natural and anthropogenic effects. Therefore, data reported herein are based on samples collected on a semimonthly basis from the exposed mudflat at low tide between January and December (Cain and others, 2021). Samples include surface sediment, the deposit-feeding clam $L$. petalum, surface water, and sediment cores for community analysis. Data on sediments, L. petalum, and surface water have been collected continuously since 1977, whereas community data were collected during 1974-1990 and 1998 to the present (2019).

\section{Measurements of Metal Exposure}

Metal concentrations in surficial sediments and in the soft tissues of $L$. petalum were interpreted as indicative of metal exposure to the broader benthic community. The collection and preparation of sediment and L. petalum samples have been described in detail, previously (see, for example, Dyke and others, 2014; Cain and others, 2021). The following is an overview of those procedures.

\section{Surface Sediment}

Sediment samples were collected from the visibly oxidized (brownish) surface layer (top 1-2 cm) of mud and later that day sieved through a 100 -micrometer $(\mu \mathrm{m})$ mesh polyethylene screen with distilled water to remove large grains that might bias interpretation of concentrations. The mesh size was chosen to match the largest grains typically found in the digestive tract of $L$. petalum. All chemical data reported herein were determined from the fraction that passed through the sieve $(<100 \mu \mathrm{m})$, termed the "silt/clay fraction."

The percentage silt/clay fraction of sediment samples was determined to provide some comparability with bulk sediment determinations such as that employed in the Regional Monitoring Program (San Francisco Estuary Institute, 1997). The sediment that did not pass through the sieve $(\geq 100 \mu \mathrm{m})$ termed the sand fraction - was collected, as was the silt/clay fraction $(<100 \mu \mathrm{m})$ (see above). Each fraction was dried to constant weight, and their percent contributions to the bulk sample were determined gravimetrically.

The silt/clay fraction was subsampled to provide replicates weighing 0.4 to 0.6 grams $(\mathrm{g})$. These were redried $\left(70{ }^{\circ} \mathrm{C}\right)$, reweighed, and then digested by hot acid reflux $(10$ milliliters $[\mathrm{mL}]$ of 16 normal [N] nitric acid). This method provides a "near-total" extraction of metals from the sediment and is comparable to the recommended procedures of the U.S. Environmental Protection Agency (EPA) and to the procedures employed in the regional monitoring program. Another set of replicate subsamples from the silt/clay fraction was directly extracted with $12 \mathrm{~mL}$ of $0.6 \mathrm{~N}$ hydrochloric acid $(\mathrm{HCl})$ for 2 hours at room temperature. This partial extraction method extracts metals bound to sediment surfaces and is operationally designed to obtain a crude chemical estimate of bioavailable metal.

The organic carbon content of surficial sediment was determined by flow isotope ratio mass spectrophotometry at the University of California (UC) at Davis Stable Isotope Facility. Weighed samples of dry, pulverized sediment were fumigated in a hydrochloric acid atmosphere overnight at the 
USGS metal bioavailability laboratory and then shipped to the UC Davis Stable Isotope Facility for analysis (see https://stableisotopefacility.ucdavis.edu for more information).

\section{Clam Tissue}

Specimens of $L$. petalum were collected by hand and placed into containers with site water. Typically, $60-120$ individual clams were collected, representing a range of sizes (shell length).

In the laboratory, clams were removed from containers and gently rinsed with deionized water to remove sediment. Clams were immersed in seawater diluted with deionized water as necessary to the equivalent of the salinity of the water at the sampling site (see below) and moved to a constanttemperature room $\left(12 \pm 1{ }^{\circ} \mathrm{C}\right)$ for 48 hours to allow for the egestion of sediment and undigested material from their digestive tracts.

\section{Sample Preparation for Metal Analysis, Excluding Mercury and Selenium}

The shell length of each clam was measured with electronic calipers and recorded digitally. Clams were separated into 1- or 2-millimeter $(\mathrm{mm})$ size classes (for example, $10.00-10.99 \mathrm{~mm}$ or $10.00-11.99 \mathrm{~mm}$ ). The soft tissues from all the individuals within a given size class were dissected from the shell and collected in preweighed $20-\mathrm{mL}$ screw-top borosilicate glass vials to form a single composite sample for elemental analysis. The vials were transferred to a convection oven $\left(70 \pm 1^{\circ} \mathrm{C}\right)$. After the tissues were dried to constant weight, they were digested by reflux in subboiling $16 \mathrm{~N}$ nitric acid. The tissue digests were then dried and metals resolubilized in $0.6 \mathrm{~N} \mathrm{HCl}$ for trace-metal analysis.

\section{Analytical, Excluding Mercury and Selenium}

Sediment and tissue concentrations of aluminum ( $\mathrm{Al})$, chromium $(\mathrm{Cr})$, copper $(\mathrm{Cu})$, iron $(\mathrm{Fe})$, nickel $(\mathrm{Ni})$, silver $(\mathrm{Ag})$, and zinc $(\mathrm{Zn})$ were determined using inductively coupled plasma optical emission spectrophotometry (ICP-OES). Samples and standard reference materials (see below) were filtered $(0.45 \mu \mathrm{m})$ prior to analysis.

\section{Sample Preparation and Analysis for Mercury and Selenium}

Approximately 40 clams were selected from each collection. The only criterion for selection was that the range of sizes (shell length) within this group was representative of the larger collection. Otherwise, the selection of individuals was random. Selected individuals were grouped according to size to form three composites, each containing a minimum of approximately $1.25 \mathrm{~g}$ wet weight. To meet this requirement, especially for the smaller clams, the 1-mm size classes were usually combined to form broader size classes (within 3-4 mm of each other, as appropriate). Once the composites were formed, the clams were dissected as described above, and the soft tissue was placed into $10-\mathrm{mL}$ screw-top polycarbonate vials. A small volume $(2-3 \mathrm{~mL})$ of double-deionized water (approximately 18 megohm centimeter $[\mathrm{M} \Omega-\mathrm{cm}]$ resistivity) was then added to the sample and subsequently homogenized with a high-speed tissue homogenizer. Once homogenized, the samples were refrozen $\left(-80^{\circ} \mathrm{C}\right)$ and then freeze-dried.

Sediment samples for mercury and selenium analyses were prepared with the same methods used for other trace elements (described above and in previous reports; see, for example, Dyke and others, 2014; Cain and others, 2021).

Tissue and sediment samples were subsampled and analyzed for total mercury by acid-digestion, $\mathrm{BrCl}$ oxidation, purge and trap, and cold vapor atomic fluorescence spectrometry according to the EPA Method 1631, Revision E (U.S. Environmental Protection Agency, 2002), and for selenium by acid digestion, hydrogen peroxide oxidation, hydride generation inductively coupled plasma mass spectrometry (HG-ICP-MS) according to a method modified from Elrick and Horowitz (1985), which was published by Kleckner and others (2017).

\section{Quality Assurance}

All glass and plastic materials used in the collection, preparation, and storage of samples were first cleaned thoroughly to remove metal contamination. Cleaning consisted of sequential immersion in a detergent bath for at least 24 hours, a rinse in deionized water, then immersion in a 10 percent $\mathrm{HCl}$ wash for at least 24 hours, followed by a thorough rinse in double-deionized water. Materials were dried in a dust-free positive-pressure environment, sealed, and stored in a dust-free cabinet.

Samples prepared for ICP-OES analysis (that is, all elements except selenium and mercury) were accompanied by procedural blanks, spiked procedural blanks and samples, and standard reference materials (SRMs) issued by the National Institute of Standards and Technology (NIST) and the National Research Council Canada (NRCC) (Cain and others, 2021). Analysis was preceded by instrument calibration, followed by quality-control checks with prepared quality-control standards before, during (approximately every 10 samples), and after each analytical run. Metal recoveries of sediment digests were evaluated with NIST 2709a San Joaquin soil and NIST 2711a Montana II soil (appendix 1). Metal recoveries for soft tissue digests were evaluated with NIST $1566 \mathrm{~b}$ oyster tissue and NRCC TORT-3 lobster hepatopancreas (appendix 2). Results were consistent within methods. Recoveries of silver, copper, nickel, and zinc from NIST 2709a and 2711a by the 
near-total extraction method were generally consistent with those reported by NIST for EPA methods 200.7 and 3050B, whereas the near-total extraction method recovered a greater percentage of total aluminum, chromium, and iron. Recoveries of elements in biological SRMs were consistently greater than 80 percent.

Analytical precision of mercury and selenium methods were determined in sample splits (appendix 3). Coefficients of variation were less than or equal to 1.56 percent.

A variety of SRMs were prepared according to the method used for the determination of selenium and mercury. Mean selenium recoveries for respective biological and sediment SRMs were 100-104 percent and 108 percent, whereas mean mercury recoveries were $90-118$ percent and 89 percent (appendix 4).

Method detection limits (MDL) and reporting levels (MRL) for ICP-OES methods were determined using the procedures outlined by Glaser and others (1981), Childress and others (1999), and U.S. Environmental Protection Agency (2004) (appendix 5).

\section{Salinity}

A small volume (approximately $25 \mathrm{~mL}$ ) of water pooled on the surface of the mudflat was collected in a polypropylene bottle and returned to the laboratory, where salinity was measured with a handheld refractometer. Additionally, salinity is determined in a small volume (approximately 1-2 mL) of bay water collected from the body cavity of L. petalum. Salinity of the surface-water sample and the body-water sample consistently agreed within 3 parts per thousand (\%o).

\section{Other Data Sources}

Precipitation data for San Francisco Bay are reported from a station at San Francisco International Airport (San Francisco WB AP, station identification SFF) and were obtained from the California Data Exchange Center (http://cdec.water.ca.gov/).

\section{Biological Response}

\section{Condition Index}

The CI is a measure of the clam's physiological state derived from the relation between soft tissue weight and shell length and reported as the soft tissue dry weight ( $\mathrm{g}$ ) for a clam of a particular shell length (mm). Specifically, for each collection, the relation between the average shell length and tissue dry weight of the composites was fit with a linear regression, and from that regression, the tissue dry weight was predicted for a normalized shell length of $25 \mathrm{~mm}$ (Cain and Luoma, 1990).

\section{Reproductive Activity}

A minimum of 10 clams of varying sizes $(\geq 10 \mathrm{~mm}$ shell length) were processed for reproductive activity concurrent with samples for metal analyses. Clams were immediately preserved in 10 percent formalin at the time of collection. The visceral mass of each clam was removed in the laboratory, stored in 70 percent ethyl alcohol. Samples were shipped to a commercial laboratory (Central Histology Facility, Sacramento, Calif.) where they were prepared using standard histological techniques. Tissues were dehydrated in a graded series of alcohol, cleared in toluene (twice for 1 hour each), and infiltrated in a saturated solution of toluene and Paraplast for 1 hour, and two changes of melted Tissuemat for 1 hour each. Samples were embedded in Paraplast in a vacuum chamber and then thin sectioned $(10 \mu \mathrm{m})$ using a microtome (Weesner, 1960). Sections were stained with Harris' hematoxylin and eosin and examined with a light microscope. Each individual was characterized by size (length, in $\mathrm{mm}$ ), sex, developmental stage, and condition of gonads, thus allowing each specimen to be placed in one of five qualitative classes of gonadal development (Parchaso, 1993).

\section{Community Analysis}

Samples for benthic community analysis were collected with a hand-held core, $8.5 \mathrm{~cm}$ in diameter and $20 \mathrm{~cm}$ deep. Three replicate samples were taken within a 1 square meter $\left(\mathrm{m}^{2}\right)$ area, defined as "the station," during each sampling date. Core placement was based on a rotating pattern in which the cores were placed on different sides of the station each month, allowing the sampling area enough time to recover, to provide an accurate representation of the benthic community. The sampling locations were (in sampling order) southeast of the station (SE), northwest of the station (NW), southwest of the station (SW), and northeast of the station (NE) (Cain and others, 2021).

Benthic community samples were washed and retained on a $500-\mu \mathrm{m}$ screen, fixed in 10 percent formalin, and then later preserved in 70 percent ethanol. Samples were stained with rose bengal solution. All animals in all samples were sorted to species level where possible, and individuals for each species were enumerated. However, some groups, such as the oligochaetes, are still not well defined in the bay and, hence, were not enumerated to the species level. Taxonomic work was performed in conjunction with a private contractor familiar with the taxonomy of San Francisco Bay invertebrates (Sarah Pearson, West Sacramento, Calif.). Pearson also compared and verified her identifications with previously identified samples.

\section{Statistical Analysis}

Metals data are reported as monthly means with associated standard deviations (SD) and annual (grand) 
means of monthly means with associated standard error of the mean (SEM). In instances where more than one sample was collected within a single month (for example, 1977-1980), the mean of those samples was calculated to harmonize the data to the study design implemented in 1994, which collects one sample within a given month. Correlations are reported as the Pearson product-moment coefficient unless otherwise stated. Groups (such as annual metal concentrations) were tested with analysis of variance ANOVA and Kruskal-Wallis. Temporal trends in the annual concentrations of metals were examined by multiple linear regression. Transformations of data for statistical analysis are explained in the results. Differences with a Type I error rate $\alpha \leq 0.05$ were considered significant. Statistical analyses were performed with Statistica v. 13 (Dell). Throughout the report, metals data are illustrated to represent interannual variation for the period of record (for silver and copper, 1977-2019, and for other metals, 1994-2019) and intra-annual variation over the past 5 years. The general patterns of seasonal variations in metal concentrations of sediment and L. petalum were based on monthly means of all samples collected since 1994 . The monthly means of samples collected from 1988-2019 were used to illustrate the seasonal variation in CI. Estimated taxa density and abundance are scaled to $1 \mathrm{~m}^{2}$ and reported as the mean $\pm \mathrm{SD}(\mathrm{n}=3)$ of the replicate cores.

\section{Results}

\section{Salinity}

Surface-water salinity in the bay is related to, and roughly the inverse of, the seasonal weather pattern in northern California, which is characterized by a winter rainy season that has been defined as months with rainfall amounts greater than 0.25 inches (in.) (November through April) and a summer dry season (May through October). Total precipitation measured at station SFF in 2019 was 22.71 in. (fig. 2). Salinity varied between 12 and $26 \%$ during 2019 (fig. 3).
A

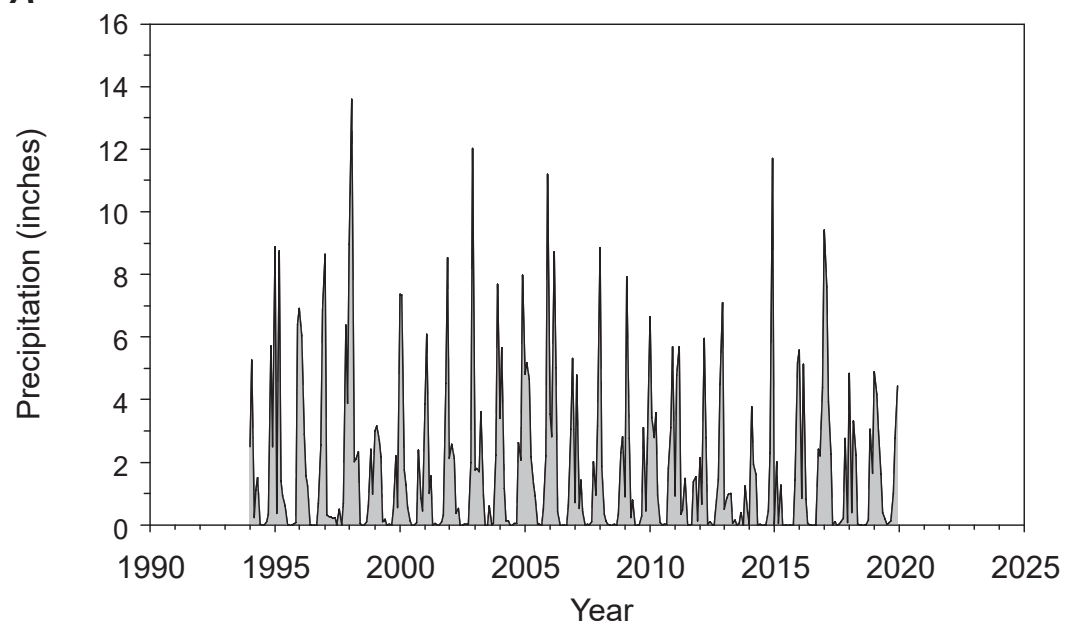

B

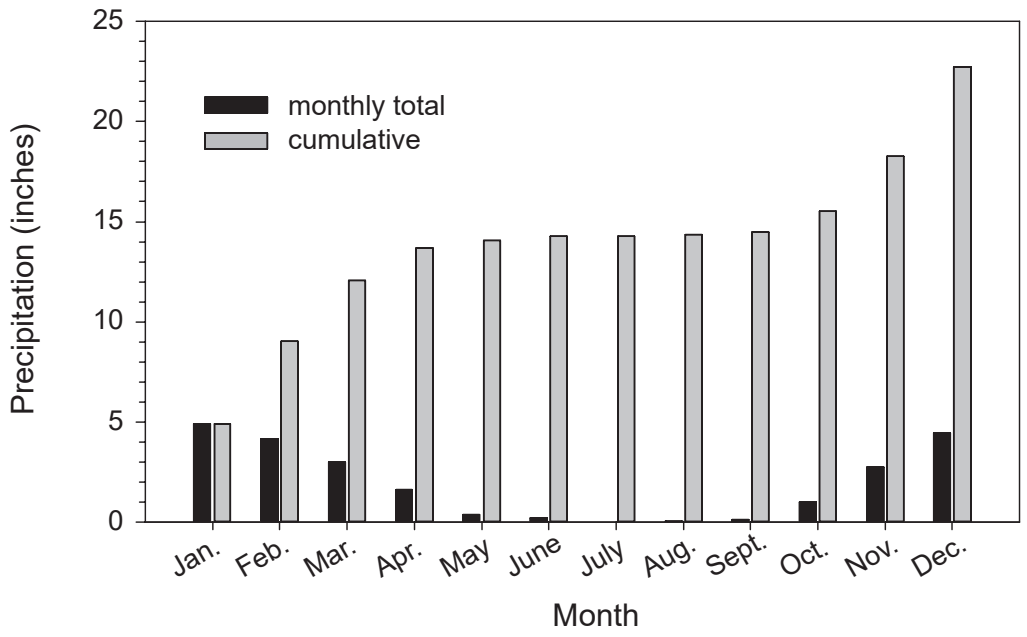

Figure 2. Graphs showing precipitation, in inches, recorded at station San Francisco WB AP, San Mateo County, Calif.; station (identification, SFF) operated by National Weather Service. $A$, Precipitation, 1994-2019. B, Monthly (dark bars) and cumulative (light bars) precipitation, 2019. 


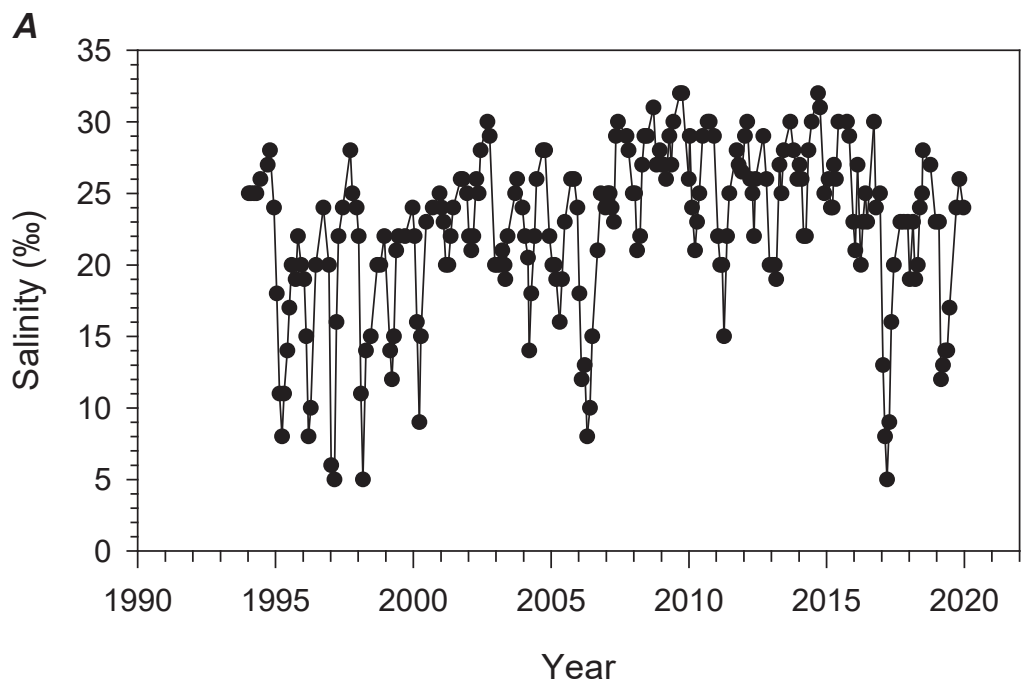

Figure 3. Surface-water salinity, in parts per thousand (\%), at Palo Alto, Calif., site, 1994-2019. A, Plot showing monthly data (dots). B, Graph showing general seasonal variation (gray boxes), as monthly averages (error bars show \pm 1 standard deviation; $\mathrm{n}=20-26)$.

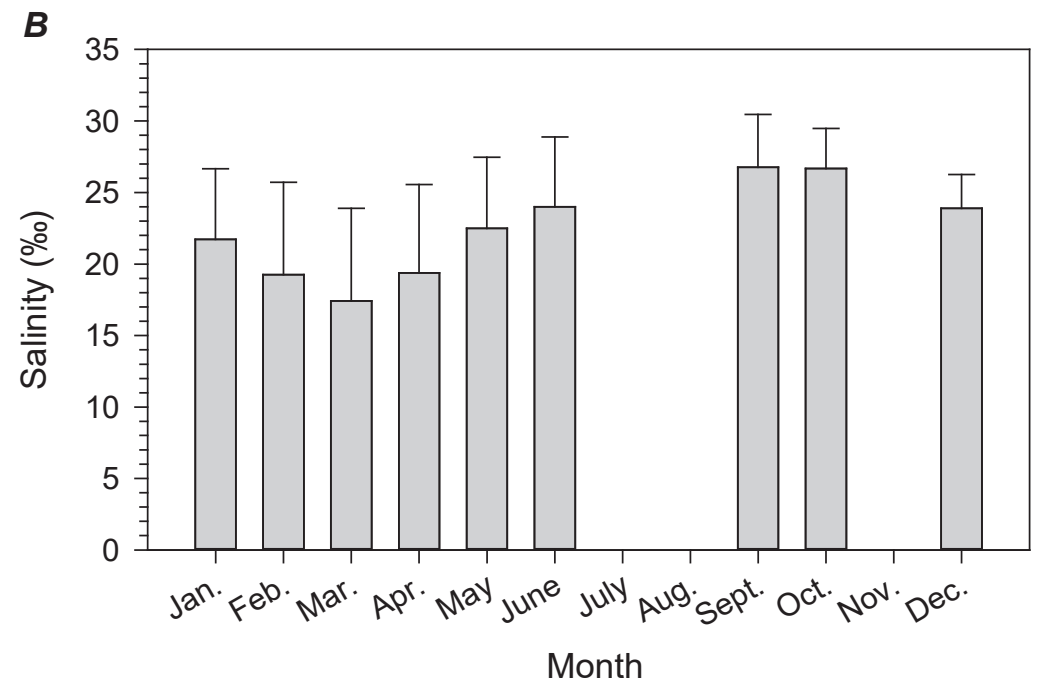

\section{Sediments}

Surficial sediment collected in this study is dominated by silt- and clay-sized particles $<100 \mu \mathrm{m}$, averaging 70 percent of the sampled sediment on a dry weight basis (table 1). These fine sediments provide large surface areas for metal sorption. Concentrations of sorbed metals vary as a function of the ratio of surface area to volume of a particle and, thus, tend to track the percentage of fine particles. Within years, metal concentrations and total organic carbon (TOC) typically are highest in winter-spring and lowest in summer-fall (fig. 4). Thomson-Becker and Luoma (1985) suggested that intra-annual variation in sediment metal concentration at the Palo Alto site is related to changes in the size distribution of sediment particles caused by allochthonous inputs and deposition of fine-grained particles in the winter and their subsequent wind-driven resuspension in the summer and fall. This explanation is supported by the seasonal periodicity displayed by the percentage of fine particles, aluminum (Al) and iron (Fe) concentrations (fig. 5), and other metals considered in this study (not illustrated). With the exception of mercury, the seasonal patterns in the concentration of individual metals and the percentage of fine grained material correlate $(r=0.67-0.90, p<0.05)$.

Sedimentary concentrations of all metals vary among years, and concentrations of some metals - notably silver and copper during the 1980s - have decreased (fig. 6). During the period 1994-2019, correlations between year and annual mean concentrations of iron (fig. 6A), copper (fig. 6E) (near total and partial extractable), zinc (near total and partial extractable) 
$\boldsymbol{A}$
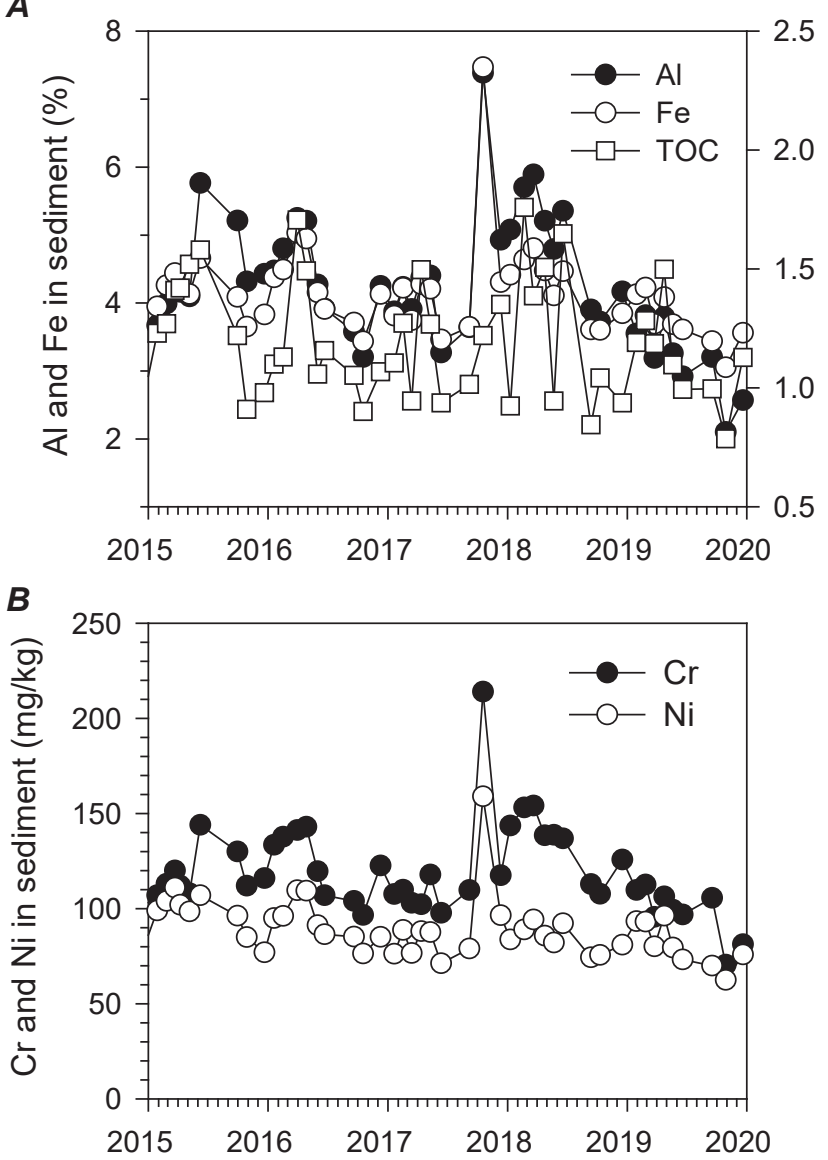

C

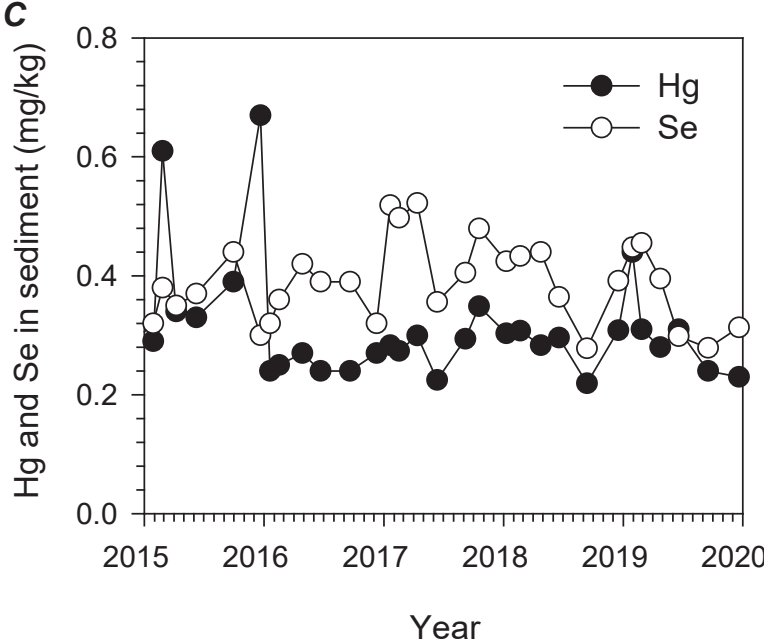

D

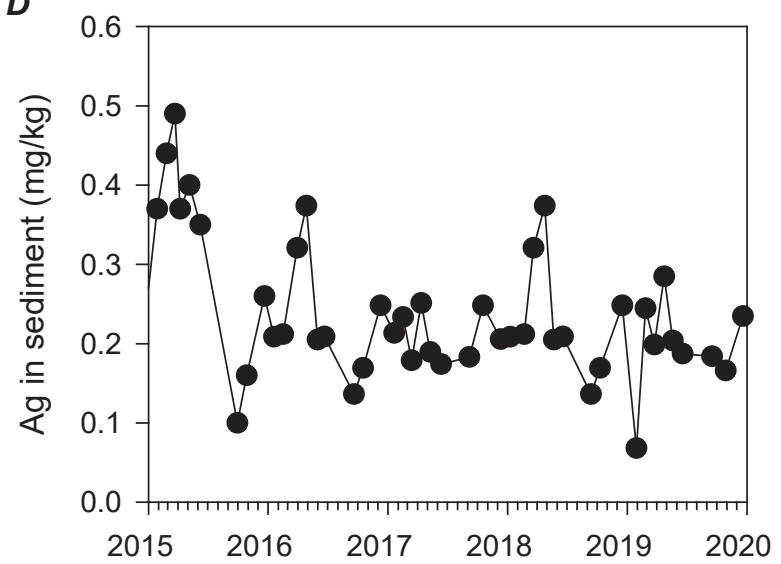

$E$

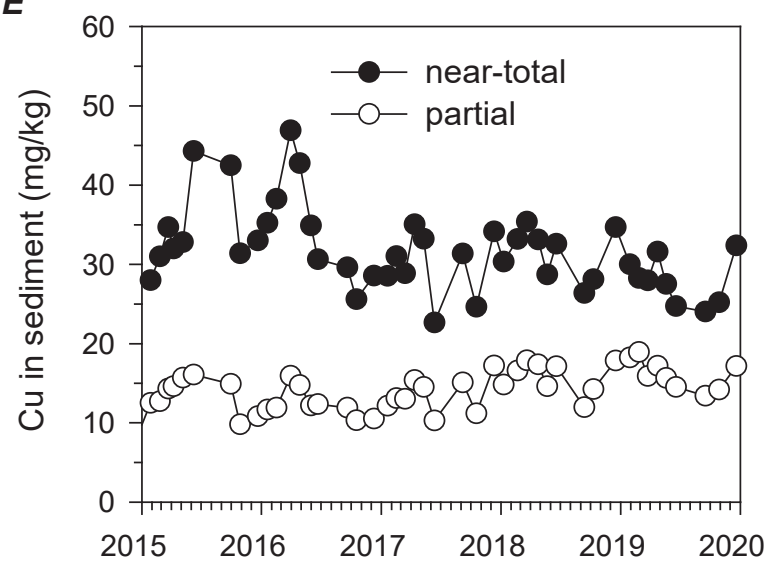

$\boldsymbol{F}$

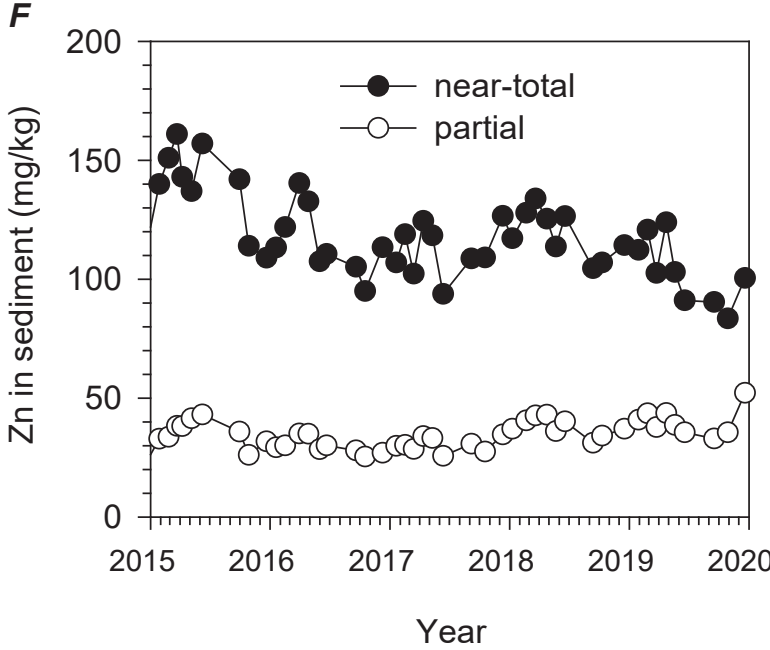

Figure 4. Plots showing concentrations of metals and total organic carbon (TOC) in sediments at Palo Alto, Calif., site, 2015-2019; data represent mean values. Other abbreviations: $\mathrm{mg} / \mathrm{kg}$, milligrams per kilogram; \%, percent. $A$, Aluminum (Al), iron (Fe), and TOC. $B$, Chromium ( $\mathrm{Cr}$ ) and nickel (Ni). C, Mercury ( $\mathrm{Hg}$ ) and selenium (Se). D, Silver (Ag). E, Near-total and partially extracted copper (Cu). F, Near-total and partially extracted zinc (Zn). 


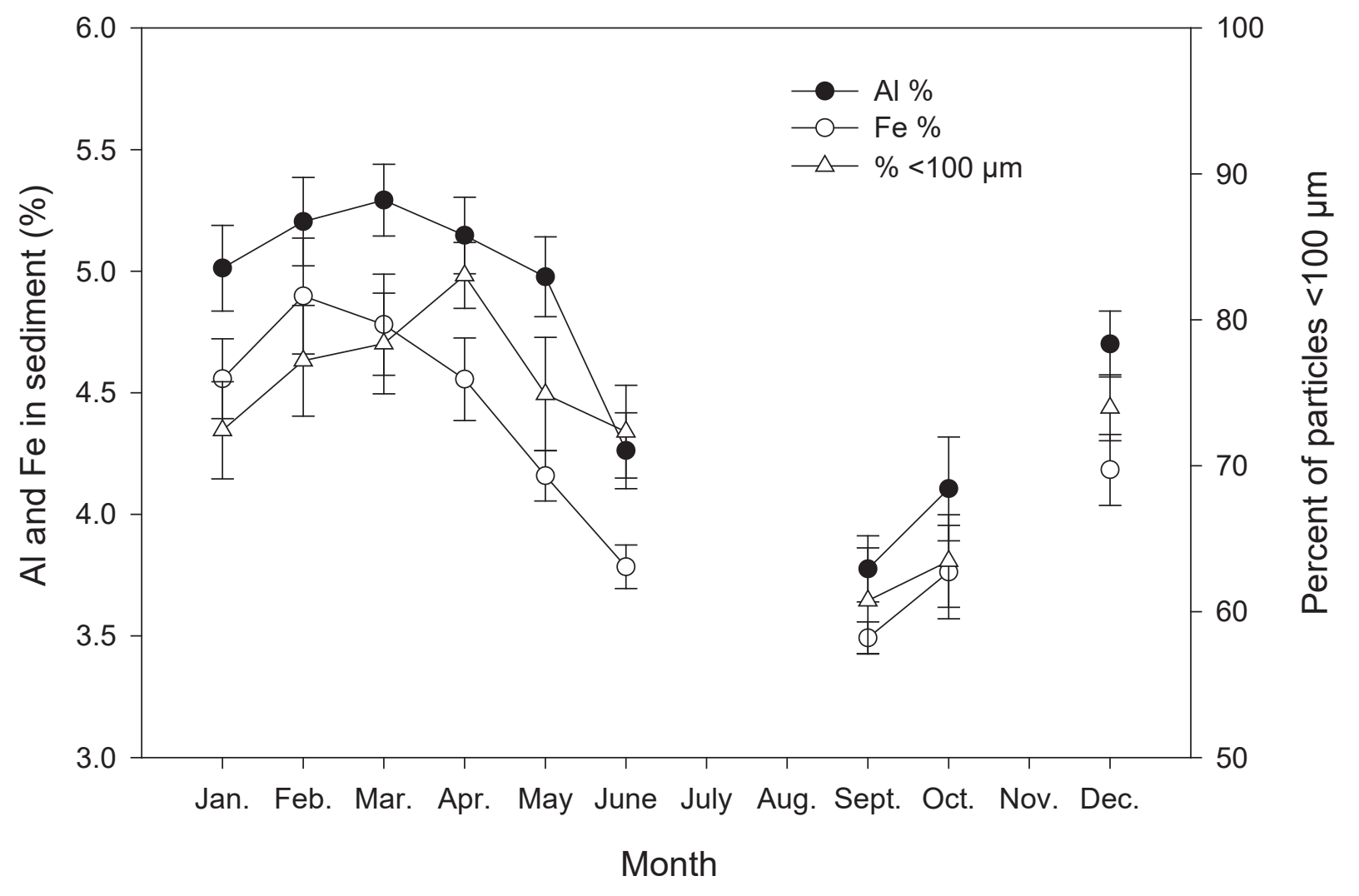

Figure 5. Plot showing general seasonal variations in aluminum (Al), iron ( $\mathrm{Fe})$, and percentage $(\%)$ of fine sediments (<100 micrometers [ $\mu \mathrm{m}])$ at Palo Alto, Calif., site; data are monthly mean of all samples collected from 1994-2019; gaps in data indicate that collections were not made in July, August, or November. Error bars show \pm standard error of mean (SEM).

(fig. $6 F$ ), and TOC (not illustrated) were significant $(p<0.05$ ) and negative, suggesting the concentration of these metals and TOC had decreased. The decrease in concentrations is modest, however. On a relative scale, the concentrations of copper, iron, and zinc are 10-37 percent less than concentrations in 1994 (TOC data for 1994 are not available). For aluminum (fig. 6A), chromium (fig. 6B), nickel (fig. 6B), mercury (fig. $6 C$ ), selenium (fig. $6 C$ ), silver (fig. $6 D$ ), and the percent of fine particles (not shown), correlations with year were insignificant $(p>0.05)$, which indicates the absence of a trend over that period.

The National Oceanic and Atmospheric Administration has developed two levels of chemical concentration to screen sediments for their probable toxicity (Long and others, 1995). The effects range low (ERL) is defined as the concentration below which the incidence of adverse effects on sensitive species is rare $(<10$ percent). Adverse effects are expected to occasionally occur at concentrations between the ERL and the effects range median (ERM). Concentrations of several metals considered in this study fall between the ERL and ERM.

Annual concentrations of chromium in surface sediment varied between 103 and 163 milligrams per kilogram $(\mathrm{mg} / \mathrm{kg})$, and nickel concentrations varied between 72 and $100 \mathrm{mg} / \mathrm{kg}$ (fig. $6 B$ ). In 2019, mean concentrations were $103 \pm 6$ and $81 \pm 4 \mathrm{mg} / \mathrm{kg}$ for chromium and nickel, respectively (table 1). Although concentrations of both elements exceed their ERLs (81 and $20.9 \mathrm{mg} / \mathrm{kg}$, respectively, for chromium and nickel), they likely reflect nonanthropogenic inputs from local watersheds that host geologic formations that are naturally enriched in both metals (Hornberger and others, 1999; Topping and Kuwabara, 2003).

Mercury concentrations in sediment from the Palo Alto site typically range between 0.24 (10th percentile) and 0.33 (90th percentile) $\mathrm{mg} / \mathrm{kg}$ and have occasionally exceeded $0.40 \mathrm{mg} / \mathrm{kg}$ (in 2004 and 2015). During 2019, mercury averaged $0.30 \pm 0.03 \mathrm{mg} / \mathrm{kg}$ (fig. $6 C$; table 1 ), with the minimum in December $(0.23 \mathrm{mg} / \mathrm{kg})$ and the maximum in January $(0.44 \mathrm{mg} / \mathrm{kg})$. Sedimentary concentrations of total mercury fall between the ERL $(0.15 \mathrm{mg} / \mathrm{kg})$ and ERM $(0.71 \mathrm{mg} / \mathrm{kg})$.

Sedimentary selenium has varied between 0.24 and $0.79 \mathrm{mg} / \mathrm{kg}$ between 1994 and 2020 (fig. 6C). The average selenium concentration in 2019 was $0.36 \pm 0.03 \mathrm{mg} / \mathrm{kg}$, similar to the concentration in 2018. 
$A$
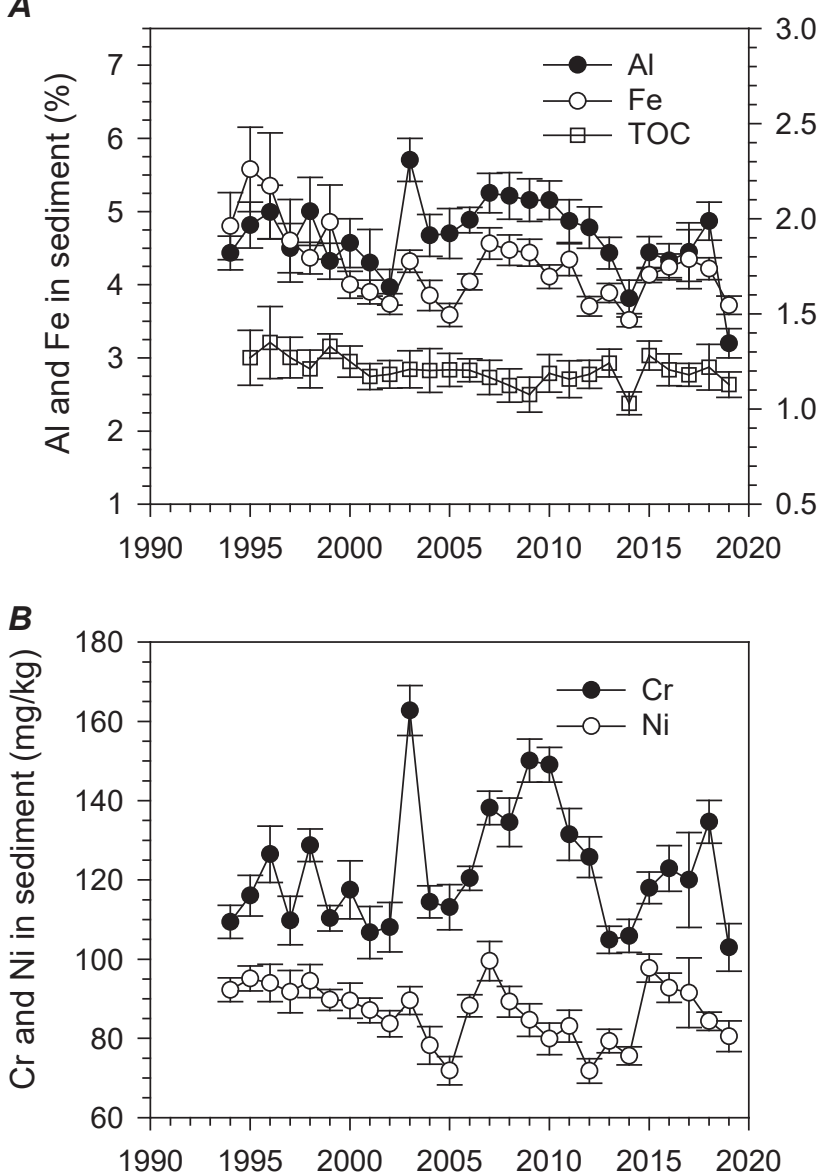

C

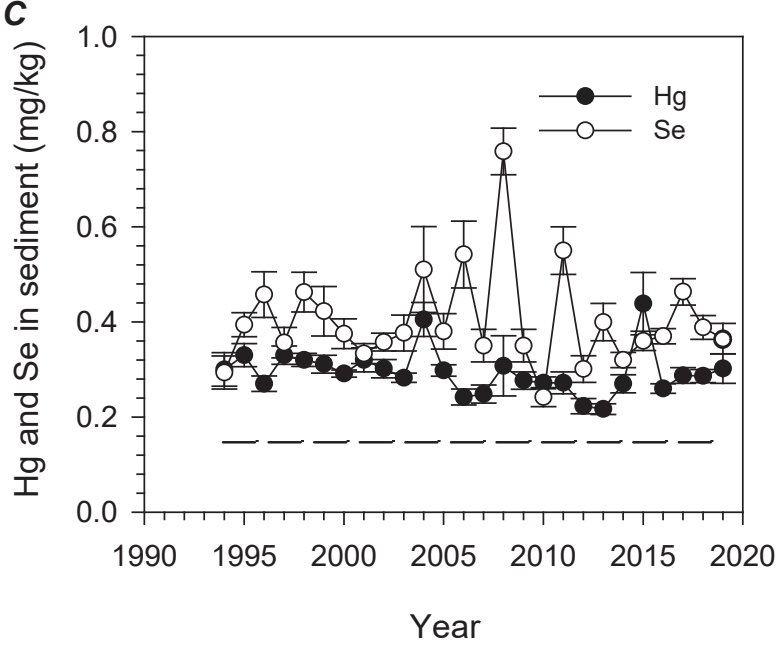

D

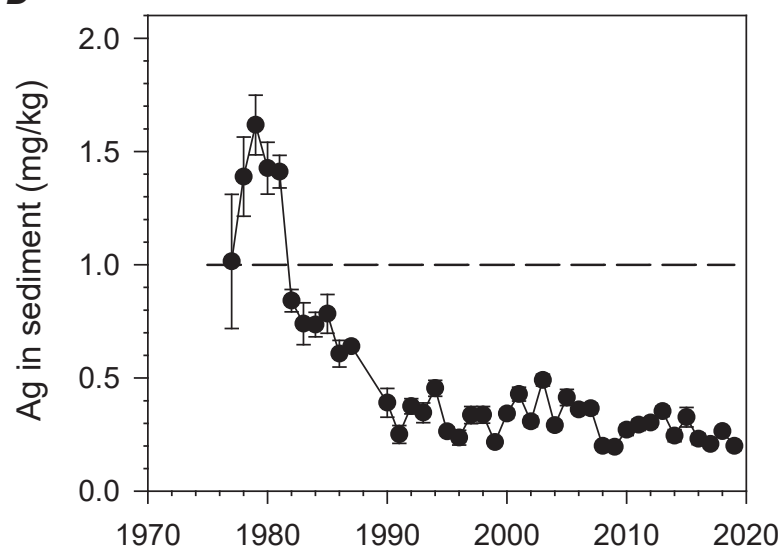

E

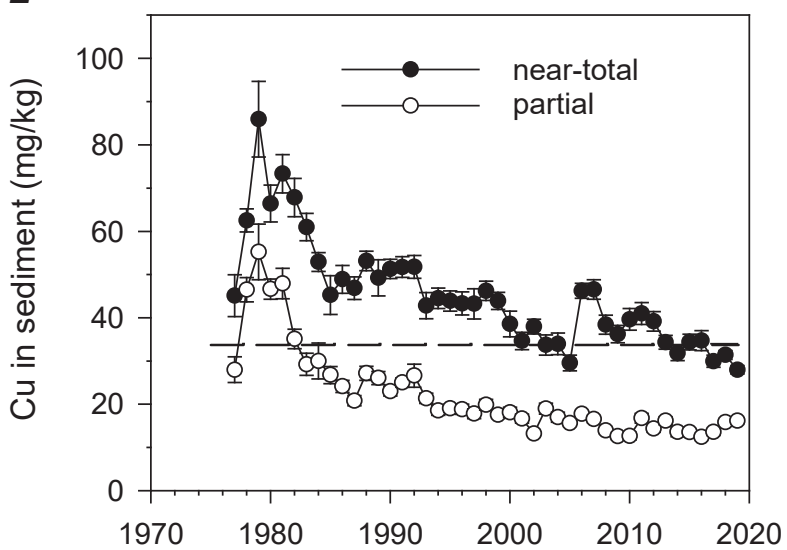

$\boldsymbol{F}$

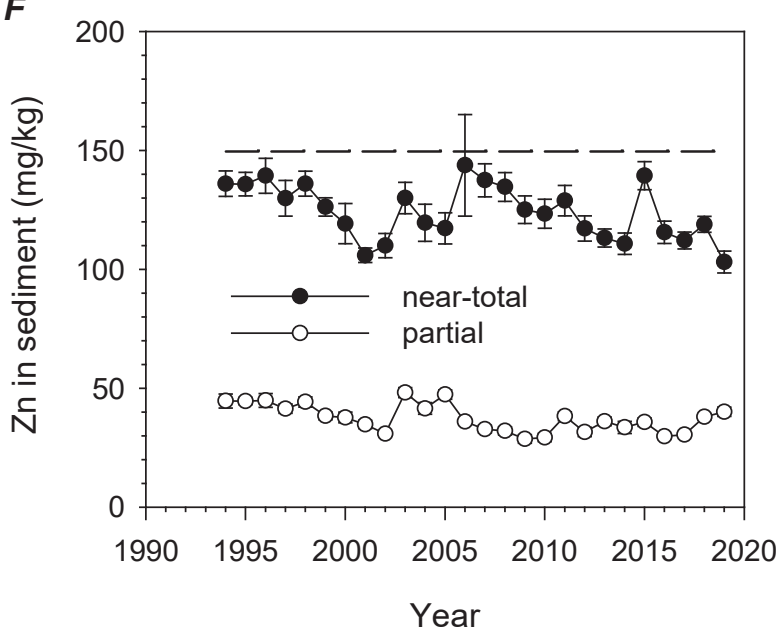

Figure 6. Plots showing annual concentrations of metals and total organic carbon (TOC) in sediments at Palo Alto, Calif., site. Data are from 1994-2019 (A, B, C, F) or 1977-2019 (D, E); values are grand mean of monthly means of samples for given year. Error bars show \pm standard error of those means (SEM). Dashed lines in $C, D, E$, and Frepresent effects range low (ERL) values, which show concentrations below which incidence of adverse effects on biota is expected to be low ( $<10$ percent). Other abbreviations: $\mathrm{mg} / \mathrm{kg}$, milligrams per kilogram; \%, percent. A, Aluminum (Al), iron ( $\mathrm{Fe}$ ), and TOC. B, Chromium ( $\mathrm{Cr}$ ) and nickel (Ni); ERL values for chromium $(81 \mathrm{mg} / \mathrm{kg}$ ) and nickel $(20.9 \mathrm{mg} / \mathrm{kg})$ not shown. C, Mercury (Hg) and selenium (Se). D, Silver (Ag). E, Near-total and partially extracted copper (Cu). F, Near-total and partially extracted zinc (Zn). 


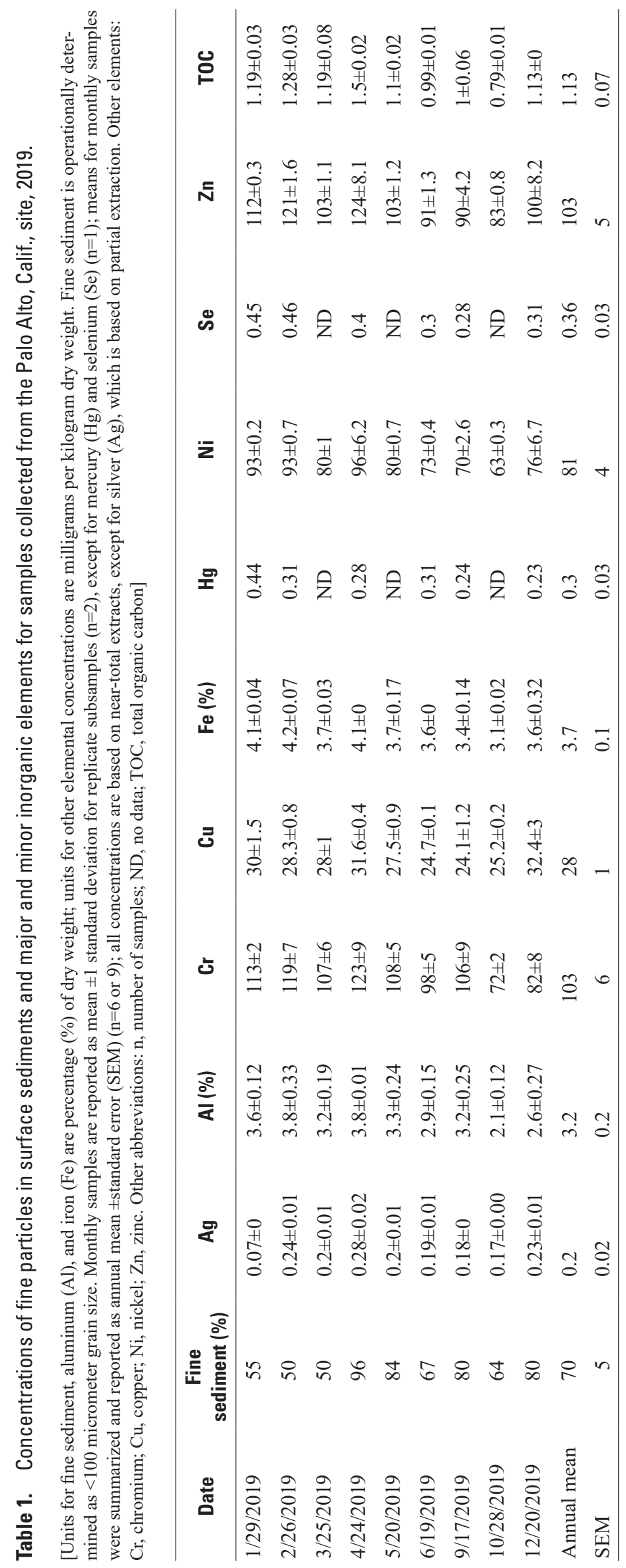


The annual mean silver concentration at the Palo Alto site was $0.20 \pm 0.02 \mathrm{mg} / \mathrm{kg}$ in 2019 . As explained earlier, silver concentrations were much higher when samples were first collected in the latter half of the 1970s. During the period 1977-1981, silver ranged between the ERL $(1.0 \mathrm{mg} / \mathrm{kg})$ and the ERM $(3.7 \mathrm{mg} / \mathrm{kg}$ ) (fig. $6 D)$, then it declined substantially during the 1980s to concentrations well below the ERL. Since 1994, silver concentrations have been relatively stable, ranging from 0.20 to $0.49 \mathrm{mg} / \mathrm{kg}$, but they still exceed what is considered the regional background concentration of $(0.10$ $\mathrm{mg} / \mathrm{kg}$ ) (Hornberger and others, 2000).

Copper (near total) has exceeded the ERL on an annual basis for most of the record (fig. $6 E$ ). However, concentrations have declined with time and have fallen below the ERL in some years, including 2019 (table 1).

Zinc concentrations on an annual basis were below the zinc ERL ( $150 \mathrm{mg} / \mathrm{kg}$ ) for the entire record (fig. $6 F$; table 1). Exceedances of near-total zinc within some years typically occurred during the winter season (for example, in years 2006 and 2015; fig. 4F). In 2019, the average annual zinc concentration was $103 \pm 5 \mathrm{mg} / \mathrm{kg}$, with a maximum concentration of $124 \mathrm{mg} / \mathrm{kg}$ in April (table 1).

\section{Clam Tissue}

Metal concentrations in the soft tissues of L. petalum display a consistent seasonal pattern characterized by fallwinter maxima and spring-summer minima with the amplitude of the cycle fluctuating from year to year (fig. 7). This variation in metal concentration reflects a combination of the metal accumulation from water and food, and the diluting and concentrating effects of gaining and losing tissue mass associated with annual growth and reproductive cycles (Cain and Luoma, 1990) represented by the CI. CI values typically increase through winter to a maximum in the spring (pre-spawning period), then taper off through summerfall (fig. 8A), a seasonal pattern that is opposite to that displayed by metal concentrations. The coupling between metal concentrations in soft tissue and recurring cycles of growth and reproduction can be illustrated, for example, by the opposing seasonal patterns in silver and the CI (fig. 8B). During the period 1994-2019, Ag correlated significantly with CI $(r=-0.96, p<0.001)$. The pattern of seasonal variation of CI in 2019 appeared typical of previous years (fig. 8A). However, data for the first three months of 2019 were accidently erased from a PC and could not be recovered. Consequently, the annual average CI ( $86 \pm 9$ milligrams [mg]) (fig. $8 C$; table 2) is for the period from April through December and, thus, is not directly comparable to estimates of prior years.

Exposures to copper and silver at the Palo Alto site are of special interest because of the high tissue concentrations observed at this site in the past (fig. $9 A$; appendix 6). The temporal patterns of $\mathrm{Ag}$ and $\mathrm{Cu}$ (fig. $9 A$ ) contrast with the pattern of Zn (fig. 9D). During 1977-1993, the ranges in annual concentrations of copper and silver were 24-282 and $3.3-113 \mathrm{mg} / \mathrm{kg}$, respectively. Since 1994 , the ranges in mean annual concentrations of copper and silver were 26-105 and $1.8-7.6 \mathrm{mg} / \mathrm{kg}$, respectively. Since 1994, annual median concentrations for copper and silver are 33 and $3.0 \mathrm{mg} / \mathrm{kg}$, respectively. In 2019, the average concentrations of copper and silver were $61.8 \pm 8.0$ and $4.22 \pm 0.47 \mathrm{mg} / \mathrm{kg}$, respectively.

Tissue concentrations of other trace metals have been relatively stable. Since 1994 the maximum/minimum ratios for concentrations of chromium (fig. 9B), nickel (fig. 9B), mercury (fig. $9 C$ ), selenium (fig. 9C), and zinc (fig. $9 D$ ) are about 2. Concentrations measured in 2019 were not atypical of concentrations in previous years, although mercury concentrations in three of the past five years have been higher than at any other time (fig. 9C). In 2019, the annual average concentrations of chromium and nickel were $3.65 \pm 0.44$ and $6.98 \pm 0.46 \mathrm{mg} / \mathrm{kg}$, respectively (table 2). Mercury was $0.49 \pm 0.05 \mathrm{mg} / \mathrm{kg}$, selenium was $4.43 \pm 0.22 \mathrm{mg} / \mathrm{kg}$, and zinc was $335 \pm 14 \mathrm{mg} / \mathrm{kg}$ (table 2).

Potential effects of sediment metal concentration and $C I$ on interannual metal concentration of $L$. petalum during the period 1994-2019 were examined by multiple regression analysis. Data were $\log 10$ transformed. Residuals were plotted against year for evidence of a trend in tissue concentrations. Statistical significance of the model was set at $\alpha \leq 0.05$. Results of these analyses indicated that the model was not predictive for the interannual variation of tissue metal concentrations, except for silver and zinc. For the latter two metals, CI was a significant predictor $(p<0.05)$, although the models explained less than one half of the variation $\left(R^{2}=0.26\right.$ for silver, $R^{2}=$ 0.40 for zinc). There was no evidence of a temporal trend for any metal. 
A

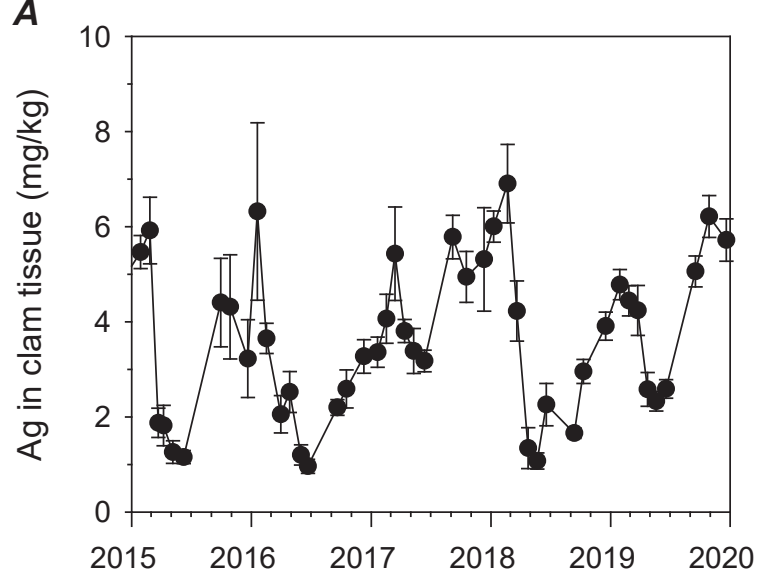

$$
\boldsymbol{B}
$$
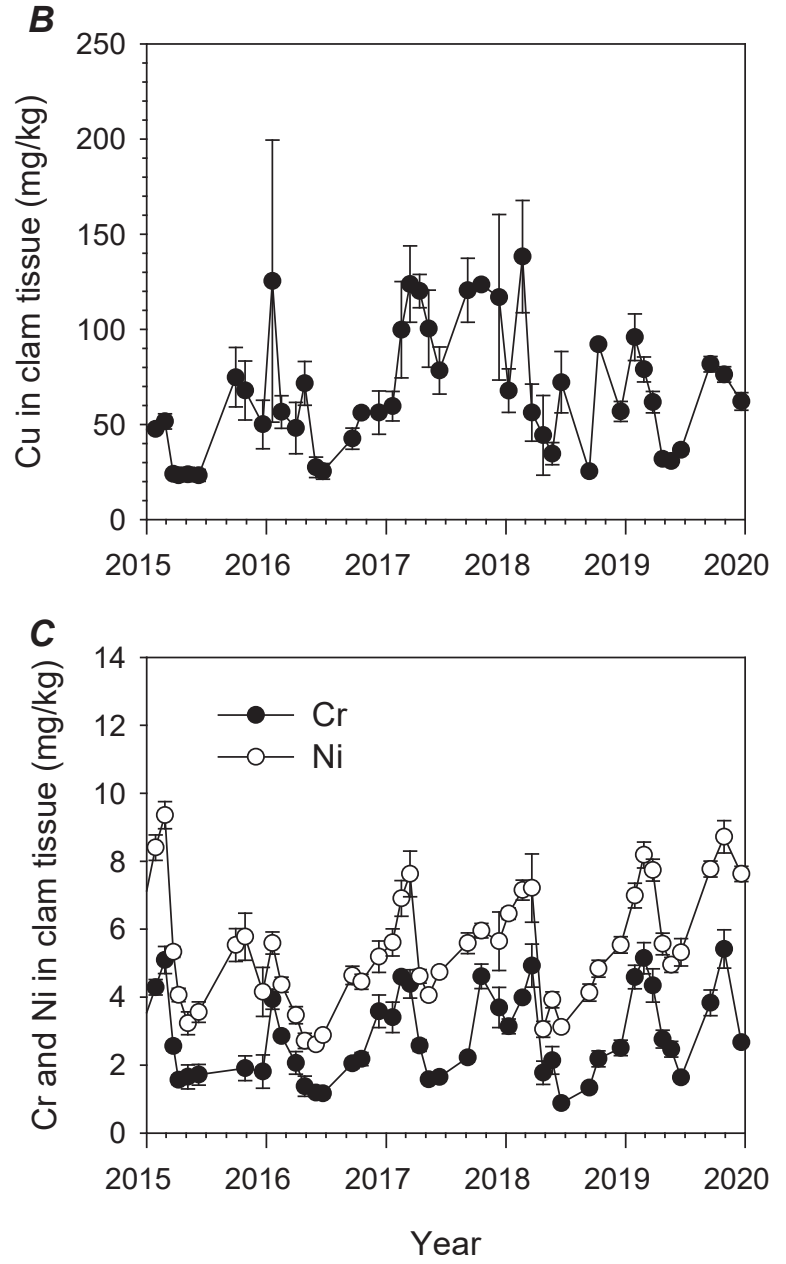
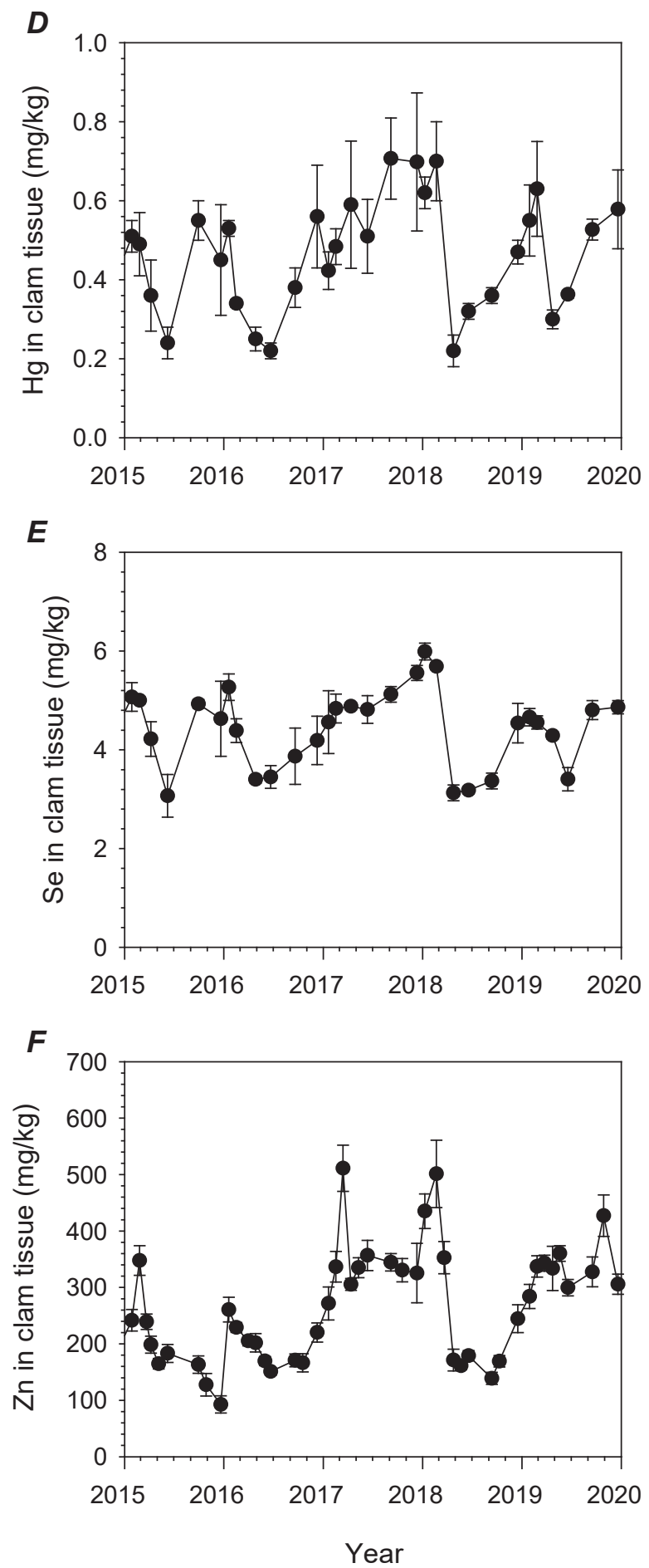

Figure 7. Plots showing metal concentrations in soft tissues of clam Limecola petalum, in milligrams per kilogram (mg/kg), at Palo Alto, Calif., site, 2015-2019; values represent mean concentration for sample collected on given date. Error bars show \pm standard error of those means (SEM). A, Silver (Ag). B, Copper (Cu). C, Chromium (Cr) and nickel (Ni). D, Mercury (Hg). E, Selenium (Se). F, Zinc (Zn). 
$A$

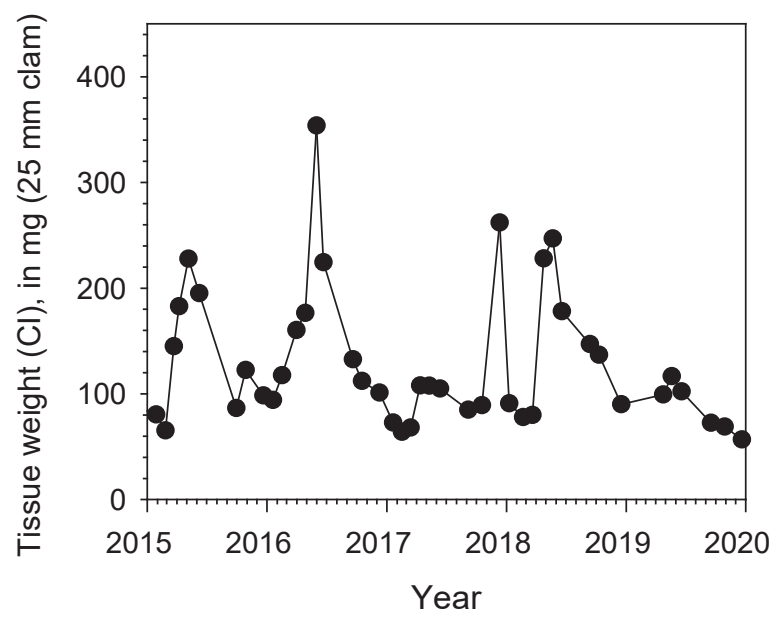

c

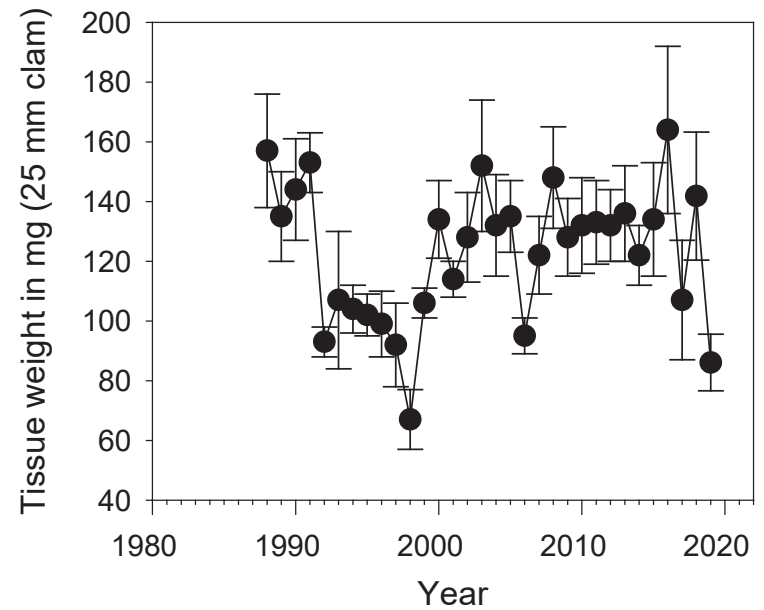

B

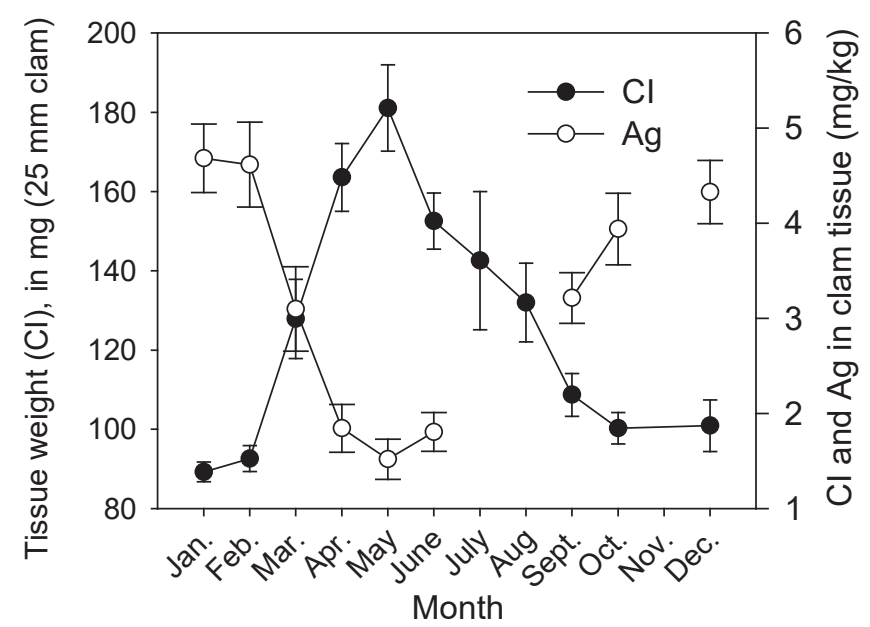

Figure 8. Plots showing condition index (CI) of clam Limecola petalum at Palo Alto, Calif., site. Condition index is defined as tissue weight (in milligrams [mg]) of soft tissues for individual clam that has shell length of 25 millimeters (mm). A, Cl, 2015-2019. B, Monthly means of Cl, 1988-2019, plotted with Ag concentrations (in milligrams per kilogram [mg/kg]), 1994-2019, illustrating general seasonal variations in $\mathrm{Cl}$ and $\mathrm{Ag}$ concentrations. Note that samples were typically not collected in July, August, or November; thus, $\mathrm{Ag}$ concentrations for those months and $\mathrm{Cl}$ for November were omitted from plot. C, Annual Cl, 1988-2019, showing grand mean of monthly means. Error bars show \pm standard error of those means (SEM). 
$\boldsymbol{A}$
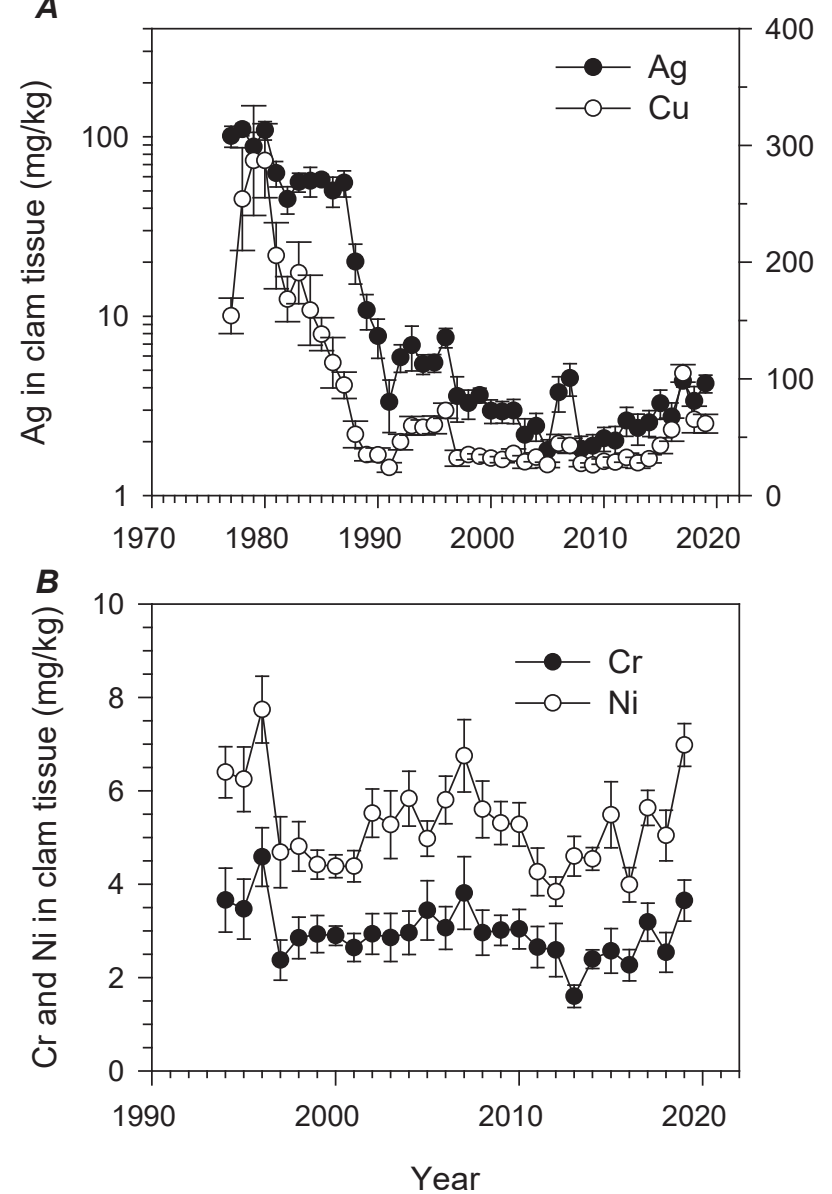
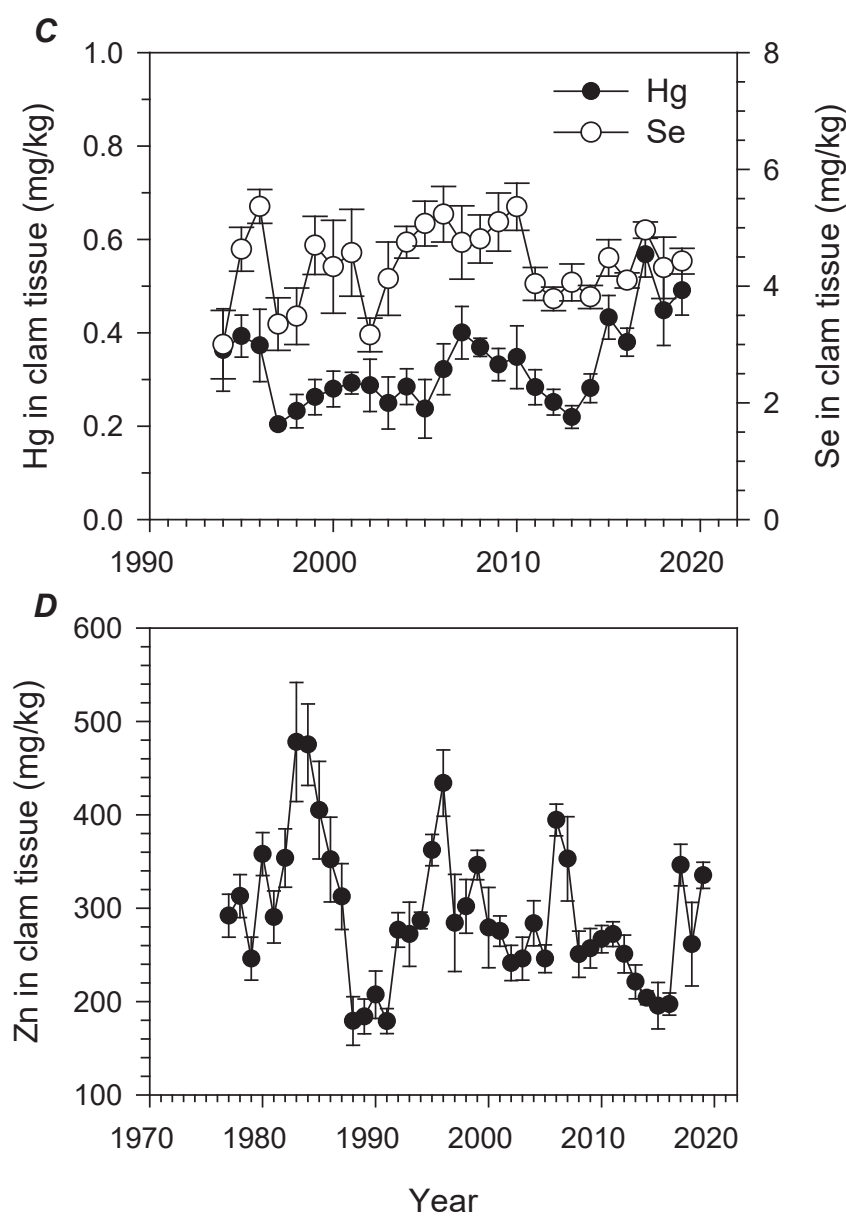

Figure 9. Plots showing metal concentrations in clam Limecola petalum, in milligrams per kilogram (mg/kg), at Palo Alto, Calif., site. Data are from 1977-2019 $(A, D)$ or 1994-2019 (B,C); values are annual (grand) mean. Error bars show \pm standard error of those means (SEM). $A$, Copper (Cu) and silver (Ag). B, Chromium ( $\mathrm{Cr}$ ) and nickel (Ni). C, Mercury ( $\mathrm{Hg}$ ) and selenium (Se). D, Zinc (Zn).

Table 2. Concentrations of trace metals in, and condition index of, clam Limecola petalum at the Palo Alto, Calif., site, 2019.

[Units for elemental concentrations are milligrams per kilogram soft tissue dry weight; units for condition index (CI) are milligrams. Condition index is defined as soft tissue weight of clam of 25-millimeter shell length. All concentrations are based on near-total extracts. Monthly data are reported as mean \pm standard deviation for replicate composites $(\mathrm{n}=8-11)$, except for selenium $(\mathrm{Se})$ and mercury $(\mathrm{Hg})(\mathrm{n}=2-3)$; means for monthly samples were summarized and reported as annual (grand) mean \pm standard error (SEM) ( $\mathrm{n}=6$ or 9). Other elements: Ag, silver; Cr, chromium; Cu, copper; Ni, nickel; $\mathrm{Zn}$, zinc. Other abbreviations: $\mathrm{n}$, number of samples; ND, no data]

\begin{tabular}{|c|c|c|c|c|c|c|c|c|}
\hline Date & $\mathbf{A g}$ & $\mathrm{Cr}$ & $\mathrm{Cu}$ & $\mathrm{Hg}$ & $\mathrm{Ni}$ & Se & $\mathrm{Zn}$ & $\mathrm{Cl}$ \\
\hline $1 / 29 / 2019$ & $4.8 \pm 0.3$ & $4.59 \pm 0.35$ & $96 \pm 12$ & $0.55 \pm 0.09$ & $7 \pm 0.4$ & $4.66 \pm 0.18$ & $284 \pm 21$ & ND \\
\hline 2/26/2019 & $4.4 \pm 0.3$ & $5.15 \pm 0.46$ & $79 \pm 7$ & $0.63 \pm 0.12$ & $8.2 \pm 0.4$ & $4.55 \pm 0.13$ & $337 \pm 19$ & ND \\
\hline 3/25/2019 & $4.2 \pm 0.5$ & $4.34 \pm 0.49$ & $62 \pm 6$ & ND & $7.7 \pm 0.3$ & ND & $343 \pm 14$ & ND \\
\hline $4 / 24 / 2019$ & $2.6 \pm 0.4$ & $2.76 \pm 0.26$ & $32 \pm 2$ & $0.3 \pm 0.02$ & $5.6 \pm 0.3$ & $4.29 \pm 0.08$ & $334 \pm 39$ & 99 \\
\hline $5 / 20 / 2019$ & $2.3 \pm 0.2$ & $2.47 \pm 0.23$ & $31 \pm 2$ & ND & $5 \pm 0.2$ & ND & $360 \pm 14$ & 117 \\
\hline $6 / 19 / 2019$ & $2.6 \pm 0.2$ & $1.63 \pm 0.1$ & $37 \pm 2$ & $0.36 \pm 0.01$ & $5.3 \pm 0.4$ & $3.41 \pm 0.24$ & $300 \pm 14$ & 102 \\
\hline 9/17/2019 & $5.1 \pm 0.3$ & $3.83 \pm 0.38$ & $82 \pm 4$ & $0.53 \pm 0.03$ & $7.8 \pm 0.2$ & $4.8 \pm 0.19$ & $327 \pm 26$ & 73 \\
\hline $10 / 28 / 2019$ & $6.2 \pm 0.4$ & $5.42 \pm 0.57$ & $76 \pm 4$ & ND & $8.7 \pm 0.5$ & $\mathrm{ND}$ & $427 \pm 37$ & 69 \\
\hline $12 / 20 / 2019$ & $5.7 \pm 0.4$ & $2.67 \pm 0.11$ & $62 \pm 5$ & $0.58 \pm 0.1$ & $7.6 \pm 0.2$ & $4.86 \pm 0.13$ & $306 \pm 18$ & 57 \\
\hline Annual mean & 4.22 & 3.65 & 61.8 & 0.49 & 6.98 & 4.43 & 335 & 86 \\
\hline SEM & 0.47 & 0.44 & 8 & 0.05 & 0.46 & 0.22 & 14 & 9 \\
\hline
\end{tabular}




\section{Reproduction of Limecola petalum}

As previously reported, reproductive output in L. petalum appeared to be impaired by high tissue concentrations of silver during the early part of the record (Hornberger and others, 1999; Shouse and others, 2003). The time series of reproductive activity shows that, following the decline in silver during the 1980s, reproductive output increased, and it has remained at relatively high levels. Unlike the earlier period, a high percentage of the animals were reproductively active at any given time, and they did not stay reproductively inactive for longer than a month or two. Moreover, normal seasonal cycling of reproduction-beginning in the fall and continuing through the following spring-is evident (figs. 10, 11; appendix 7).

\section{Benthic Community}

Estimates of benthic species diversity and total animal abundance are fundamental metrics that are used in assessing environmental stress on biological communities. Species diversity at the Palo Alto site, as estimated by a time series of number of species, was at a minimum in 1998, trended upward through 2012, and has shown a slight decline since its peak in 2012 (fig. 12). Total animal abundance has varied significantly during the sampling period (fig. 13). The difficulty with these types of metrics is that they do not consider the possibility that one species can take the place of another or that high abundance is based on one species. The community structure and function may change as a result of shifts in species composition, depending on the characteristics of a newly
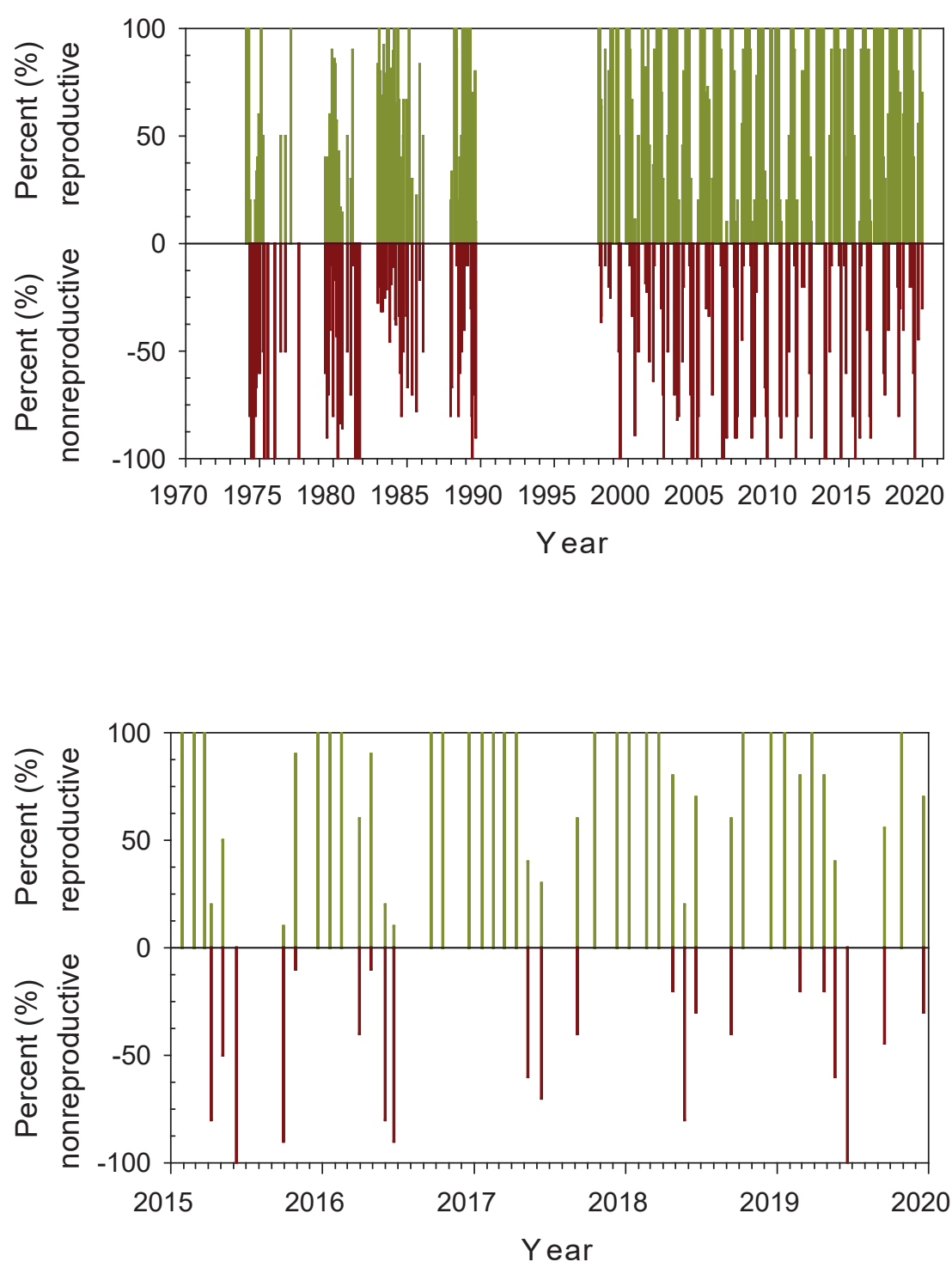

Figure 10. Reproductive activity of clam Limecola petalum at Palo Alto, Calif., site, 1974-2019. Values are percentages $(\%)$ of individuals that either were in various stages of reproduction (reproductive; shown in green, as positive values) or were reproductively inactive (nonreproductive; shown in red, as negative values).

Figure 11. Reproductive activity of clam Limecola petalum at Palo Alto, Calif., site, 2015-2019. Values are percentages (\%) of individuals that either were in various stages of reproduction (reproductive; shown in green, as positive values) or were reproductively inactive (nonreproductive; shown in red, as negative values). 
A

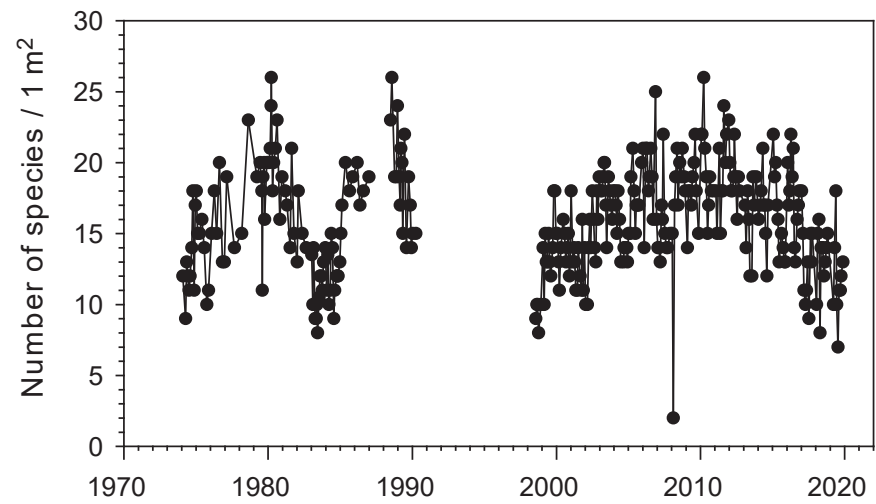

B

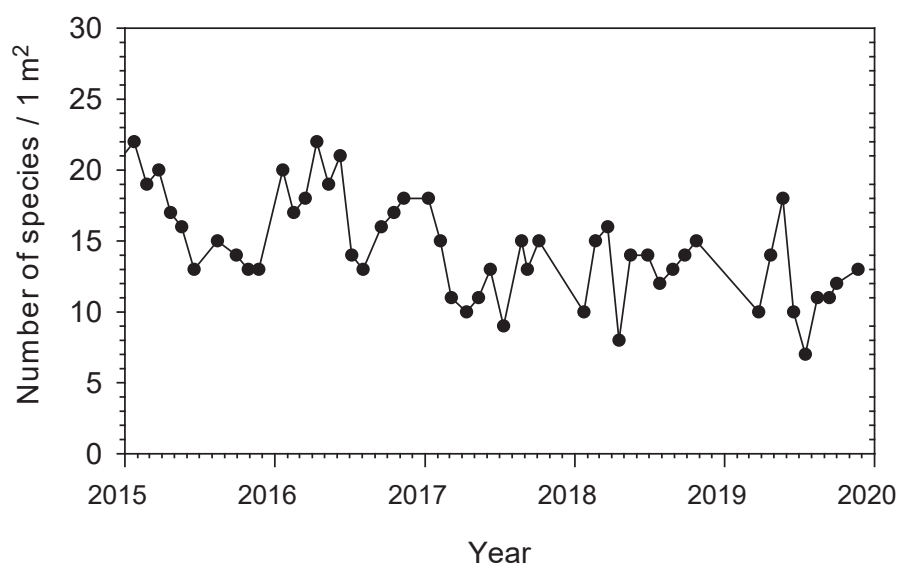

Figure 12. Plots showing total number of species present at Palo Alto, Calif., sampling site in $(A)$ 1974-2019 and $(B)$ 2015-2019; sampling site was 1 square meter $\left(\mathrm{m}^{2}\right)$. Note that collections were not made in 1987 nor between 1991 and 1997.

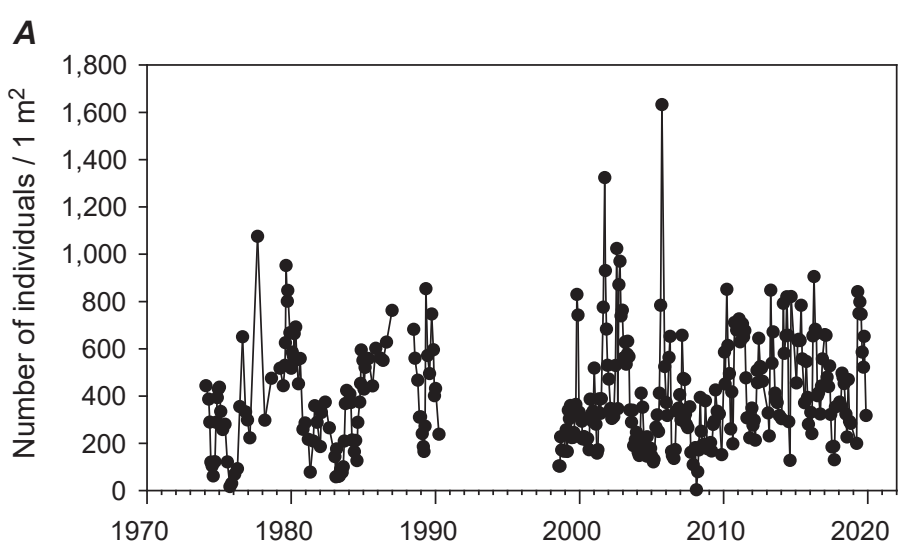

B

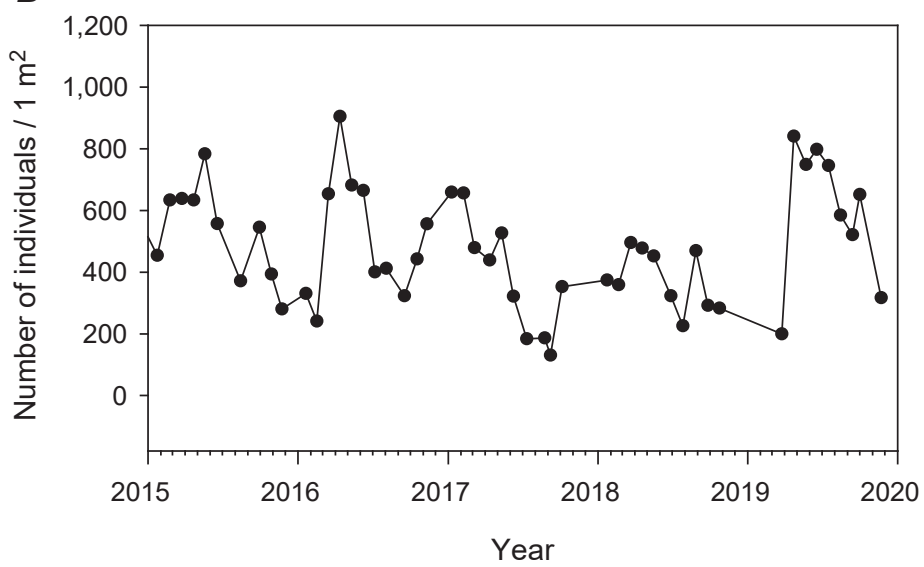

Figure 13. Plots showing total average number of individuals present at Palo Alto, Calif., sampling site in (A) 1974-2019 and (B) 2015-2019; sampling site was 1 square meter $\left(\mathrm{m}^{2}\right)$. Note that collections were not made in 1987 nor between 1991 and 1997. 
introduced or newly dominant species. The details of changes in species composition are important because they may reflect the relative ability of species to accommodate environmental stress and redistribute site resources. In general, the species composition at the study site has changed little since 1998, although there have been seasonal eruptions of several species in some years.

Three common bivalves (Limecola petalum, Mya arenaria, and Gemma gemma) have not shown any consistent trend over the 45-year period from 1974 to 2019 (figs. 14-16). Species abundance has shown significant seasonal and interannual variability for all species found at the Palo Alto site. The three common bivalves illustrate this variability well. $G$. gemma has been particularly volatile since 2005. Its abundance dropped to near zero in late fall 2007 and subsequently took three years to recover to previous average densities, which have continued through the present (2019).

Six species have shown trends in their abundance since the 1970s. Ampelisca abdita is a small crustacean that lives above the surface of the mudflat in a tube built from selected sediment particles. A. abdita showed a general decline in abundance (fig. 17) after 1998, and mostly low abundances persisted through the present (2019). Streblospio benedicti is a small polychaete worm that also builds a tube above the surface of the mudflat. $S$. benedicti abundance has declined through the study years and, over the past 9 years, the species has maintained a seasonal pattern of increasing spring abundance followed by a fall-winter decline (fig. 18). The abundance of the small burrowing crustacean Grandidierella japonica, a deposit feeder, became more seasonally consistent after 2000 (fig. 19), with particularly low abundances in 2006, 2007, and 2011. This species has shown a consistent seasonal peak in abundance in the fall since 1999, with the exception of 2011. Alitta succinea, a burrowing polychaete that feeds on surface deposits and scavenges for detrital food, showed large seasonal fluctuations in abundance throughout the study (fig. 20). Similar to other species, its abundance declined in 2011 and remains in low numbers today (2019).

Two species showed an increase in abundance within the time series. The first species, Heteromastus filiformis (fig. 21), is a burrowing, subsurface-deposit-feeding polychaete worm that lives deep in the sediment (usually 5-20 cm below the surface of the mudflat). Its abundance increased sharply in 1985 and then partly receded in the late 1980s. Abundance remained higher than in the late 1970s until a decline in 2008 and a slight increase after 2010 (fig. 21). Data from the 1980s indicate that abundance for this species increases slowly, possibly because of their egg-laying mode of recruitment. The second species showing an increase was Nippoleucon hinumensis, a small, burrowing, surface-deposit-feeding crustacean, which appeared in the dataset in 1988 (fig. 22) following its introduction into the bay in 1986 (Cohen and Carlton, 1995).
$A$

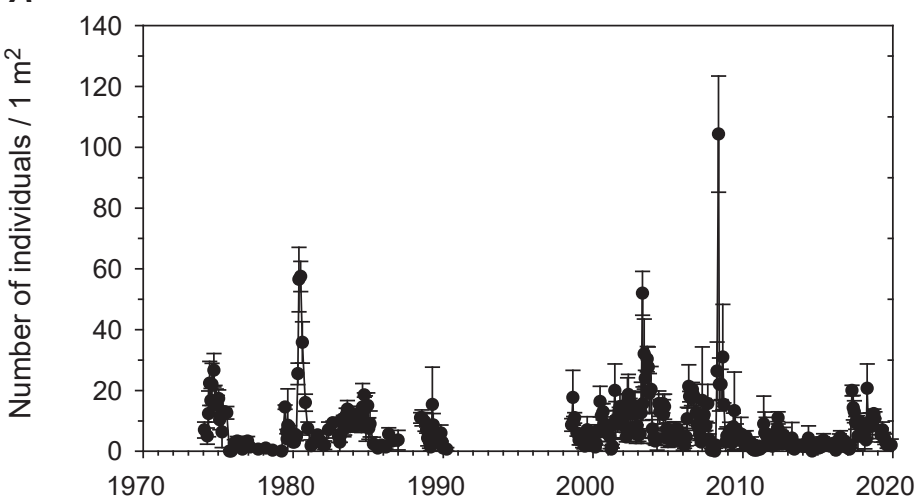

B

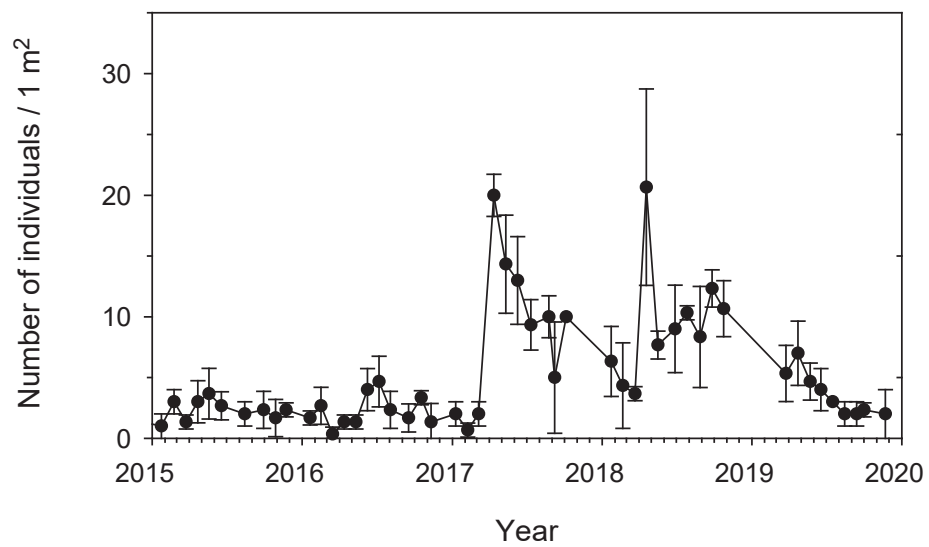

Figure 14. Plots showing monthly average abundances of Limecola petalum at Palo Alto, Calif., sampling site in $(A)$ 1974-2019 and $(B)$ 2015-2019; sampling site was 1 square meter $\left(\mathrm{m}^{2}\right)$. Error bars show \pm standard deviation from three replicate samplings. Note that collections were not made in 1987 nor between 1991 and 1997. 


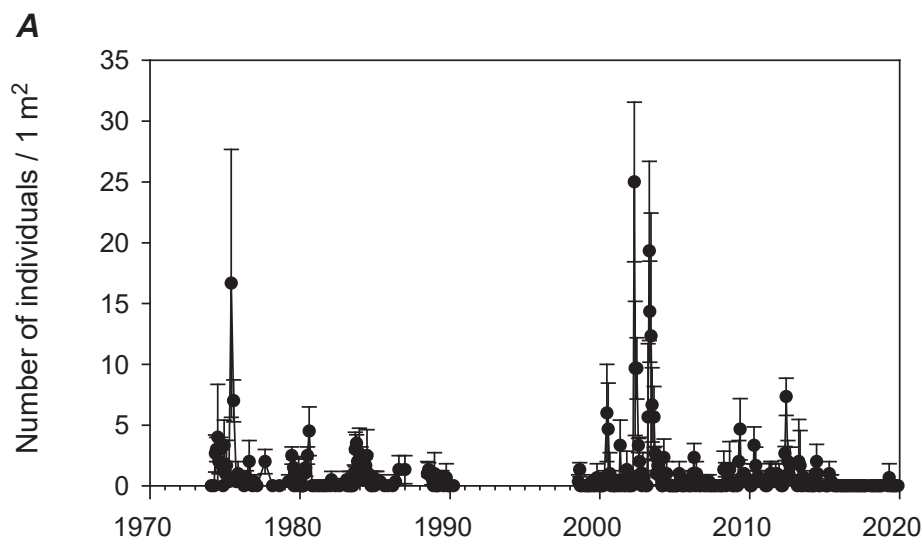

Figure 15. Plots showing monthly average abundances of Mya arenaria at Palo Alto, Calif., sampling site in $(A)$ 19742019 and $(B)$ 2015-2019; sampling site was 1 square meter $\left(\mathrm{m}^{2}\right)$. Error bars show \pm standard deviation from three replicate samplings. Note that collections were not made in 1987 nor between 1991 and 1997.
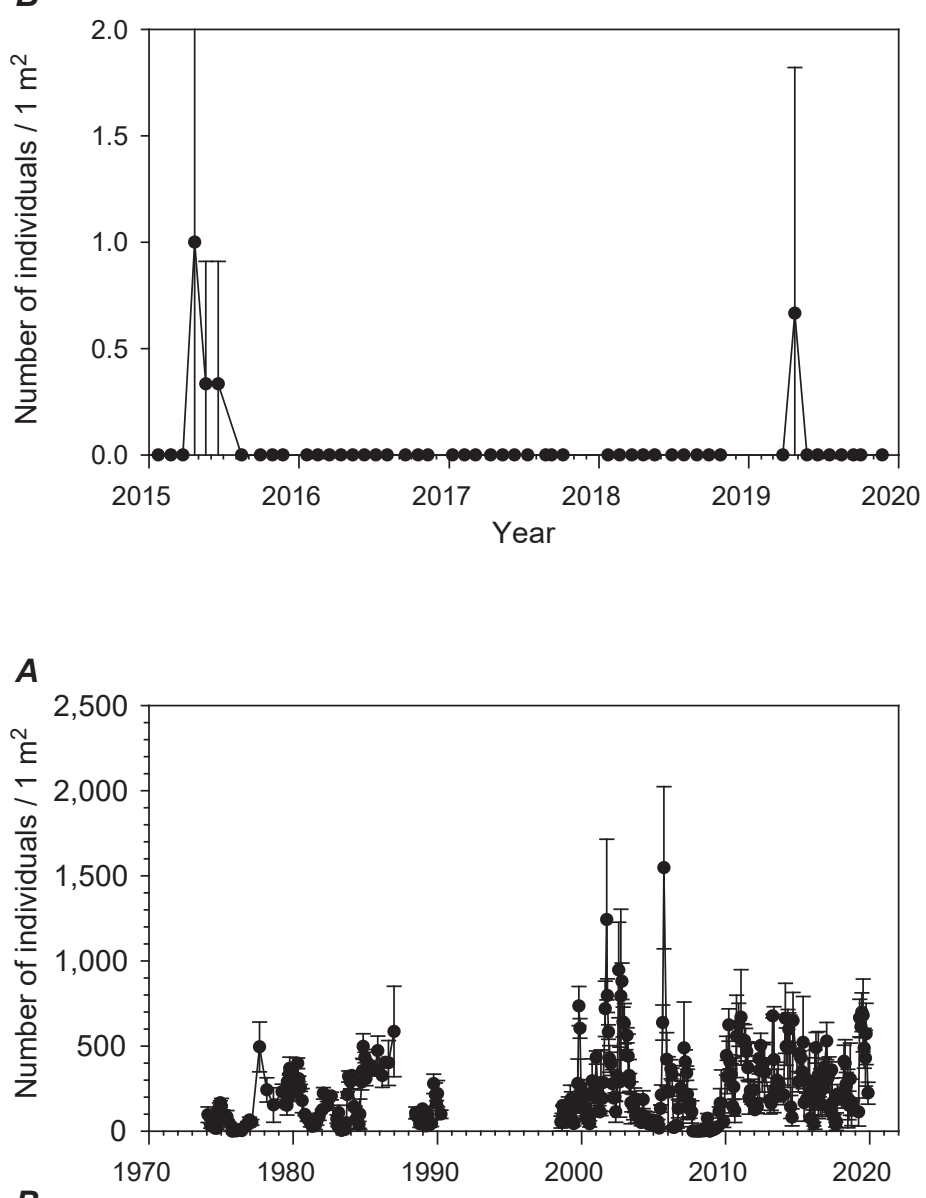

Figure 16. Plots showing monthly average abundances of Gemma gemma at Palo Alto, Calif., sampling site in $(A)$ 1974-2019 and $(B)$ 2015-2019; sampling site was 1 square meter $\left(\mathrm{m}^{2}\right)$. Error bars show \pm standard deviation from three replicate samplings. Note that collections were not made in 1987 nor between 1991 and 1997.

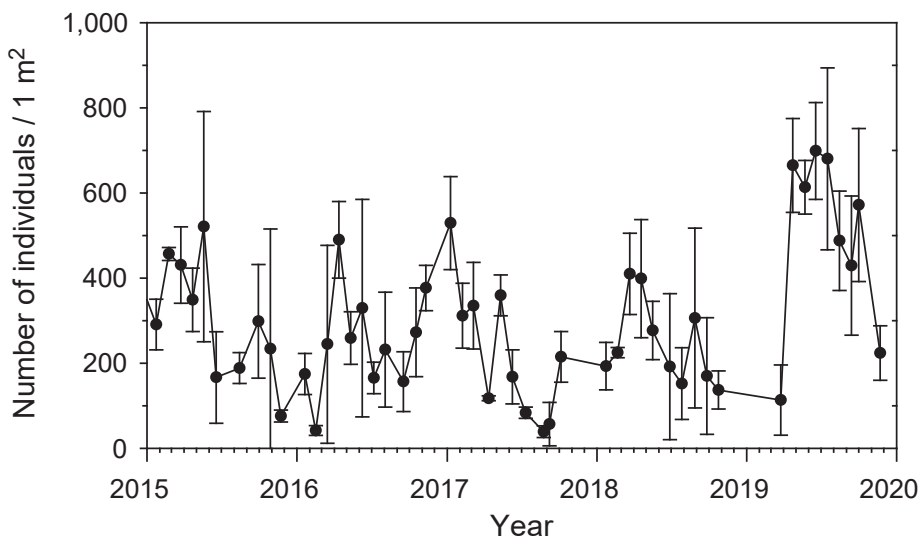


$\boldsymbol{A}$

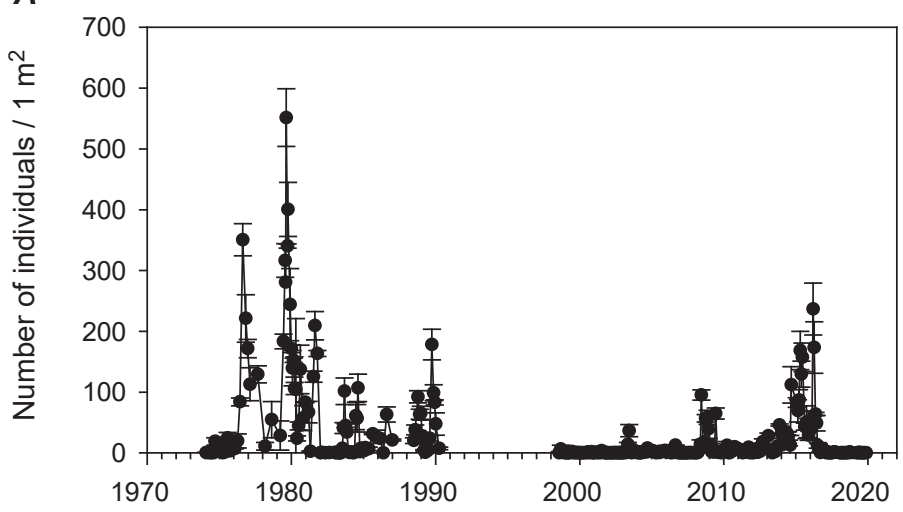

B

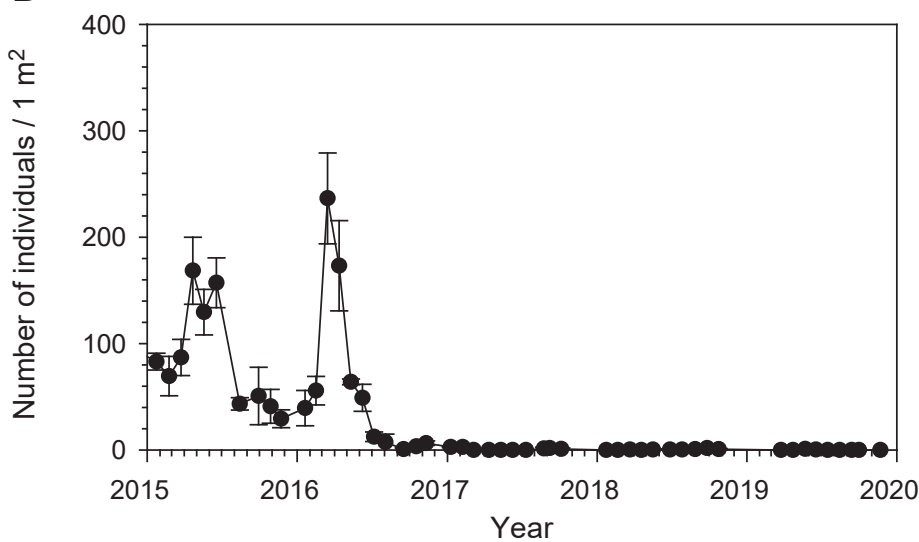

Figure 17. Plots showing monthly average abundances of Ampelisca abdita at Palo Alto, Calif., sampling site in $(A)$ 1974-2019 and (B) 2015-2019; sampling site was 1 square meter $\left(\mathrm{m}^{2}\right)$. Error bars show \pm standard deviation from three replicate samplings. Note that collections were not made in 1987 nor between 1991 and 1997.

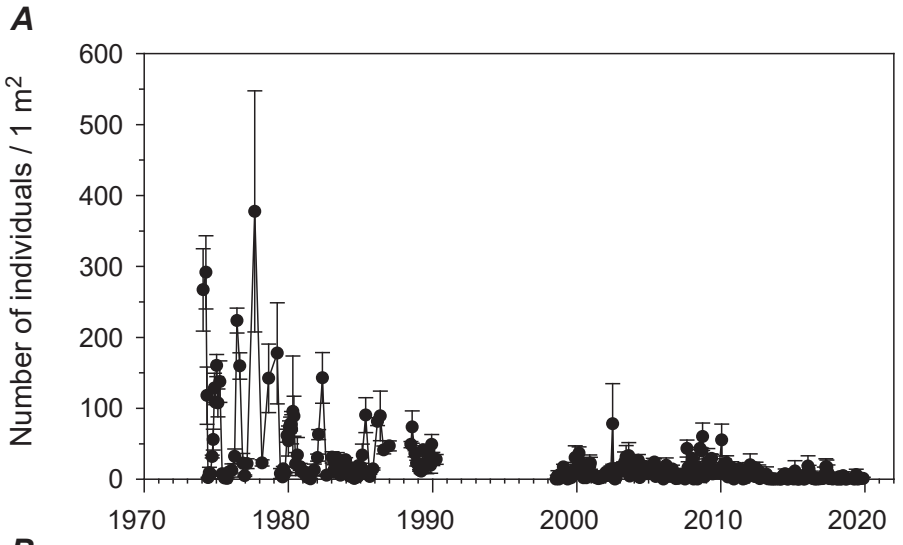

Figure 18. Plots showing monthly average abundances of Streblospio benedicti at Palo Alto, Calif., sampling site in $(A)$ 1974-2019 and (B) 2015-2019; sampling site was 1 square meter $\left(\mathrm{m}^{2}\right)$. Error bars show \pm standard deviation from three replicate samplings. Note that collections were not made in 1987 nor between 1991 and 1997.

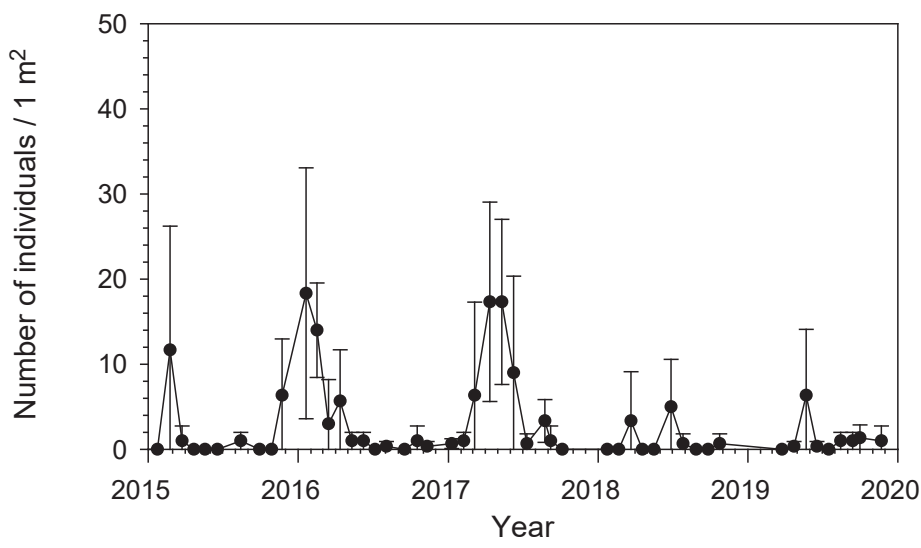




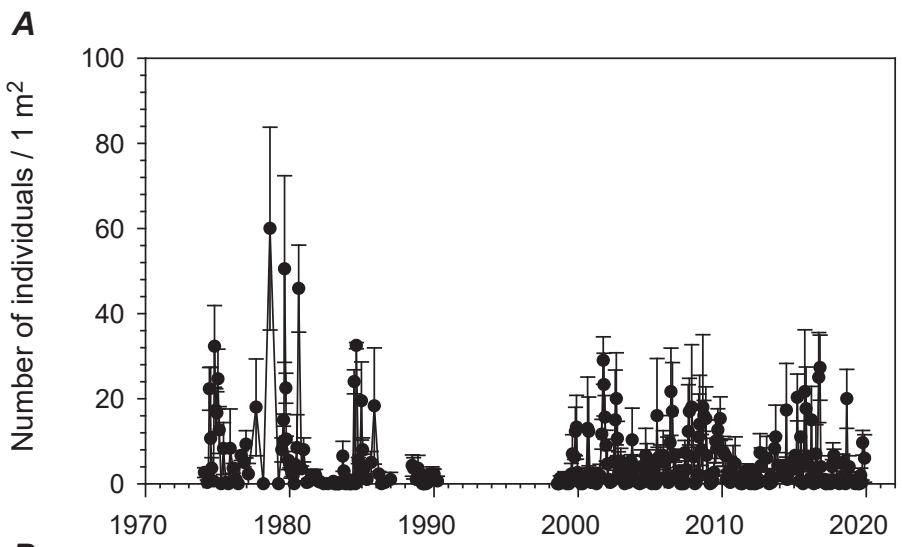

Figure 19. Plots showing monthly average abundances of Grandidierella japonica at Palo Alto, Calif., sampling site in (A) 1974-2019 and (B) 2015-2019; sampling site was 1 square meter $\left(\mathrm{m}^{2}\right)$. Error bars show \pm standard deviation from three replicate samplings. Note that collections were not made in 1987 nor between 1991 and 1997.

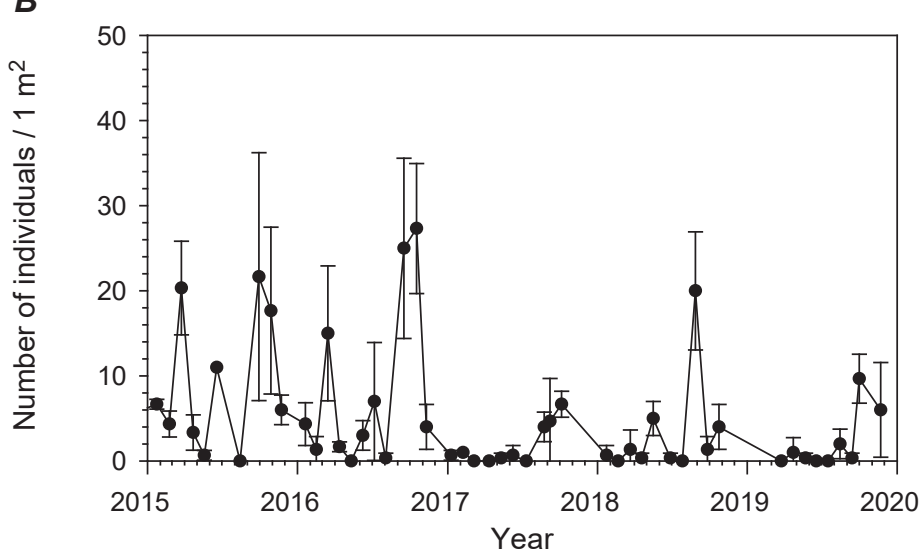

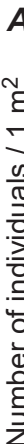

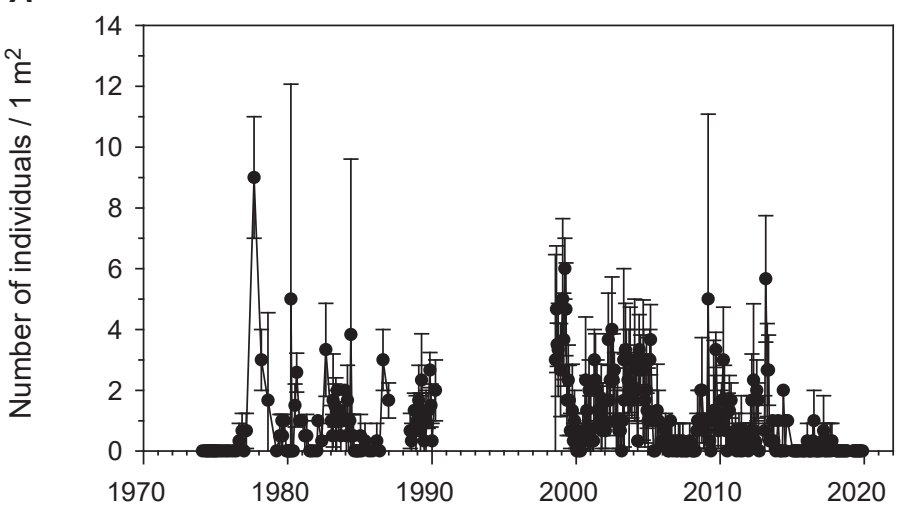

Figure 20. Plots showing monthly average abundances of Alitta succinea at Palo Alto, Calif., sampling site in $(A)$ 1974-2019 and $(B)$ 2015-2019; sampling site was 1 square meter $\left(\mathrm{m}^{2}\right)$. Error bars show \pm standard deviation from three replicate samplings. Note that collections were not made in 1987 nor between 1991 and 1997.

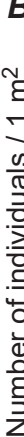

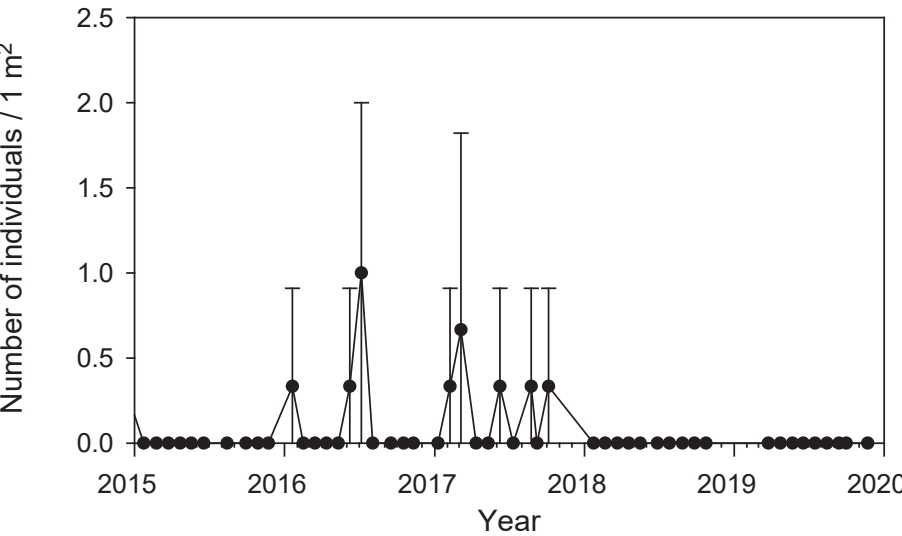


A

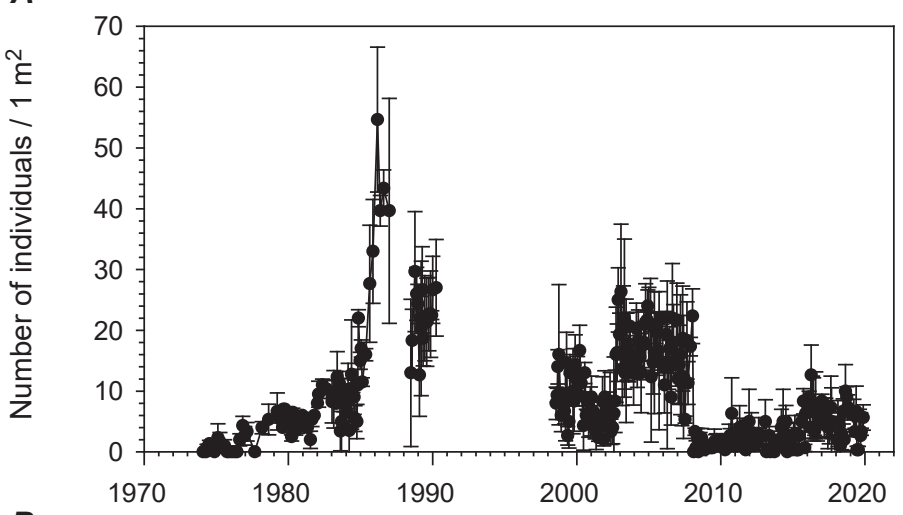

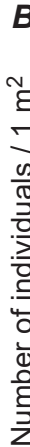

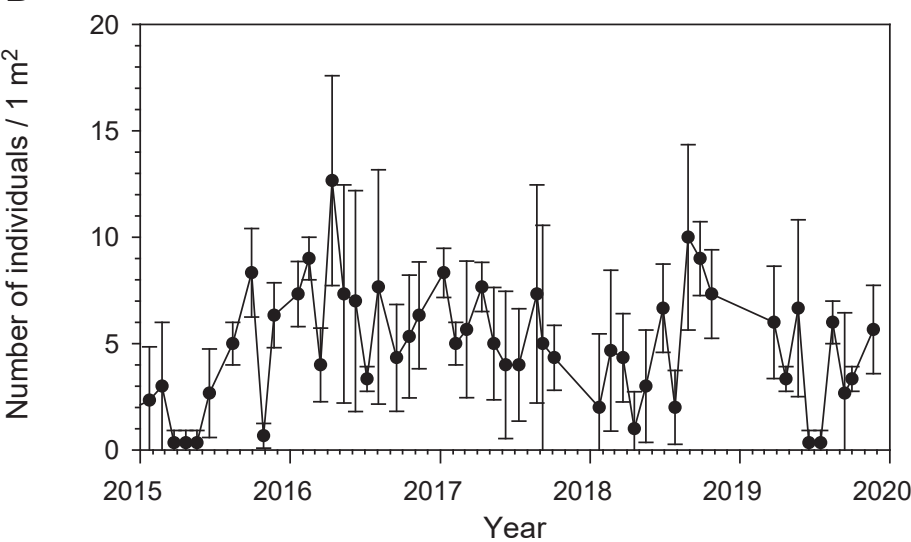

Figure 21. Plots showing monthly average abundances of Heteromastus filiformis at Palo Alto, Calif., sampling site in (A) 1974-2019 and (B) 2015-2019; sampling site was 1 square meter $\left(\mathrm{m}^{2}\right)$. Error bars show \pm standard deviation from three replicate samplings. Note that collections were not made in 1987 nor between 1991 and 1997.
$A$

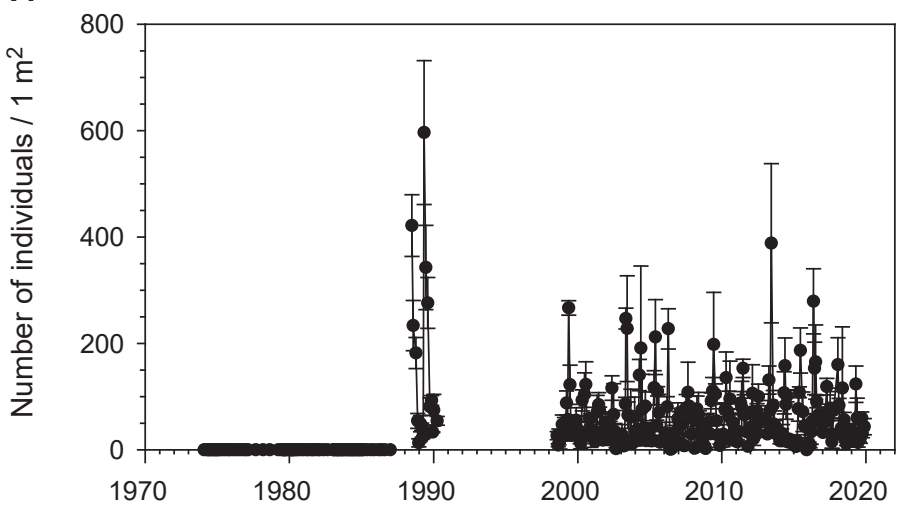

$B$

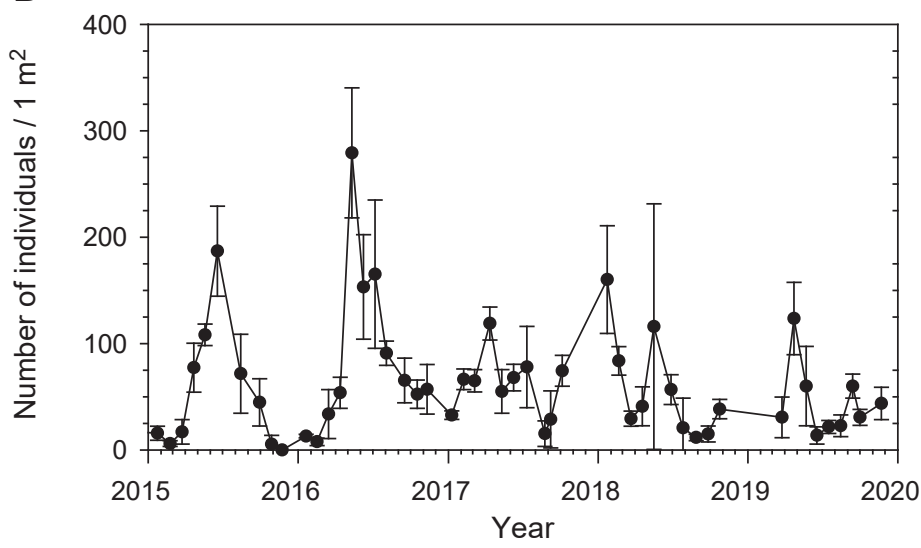

Figure 22. Plots showing monthly average abundances of Nippoleucon hinumensis at Palo Alto, Calif., sampling site in (A) 1974-2019 and (B) 2015-2019; sampling site was 1 square meter $\left(\mathrm{m}^{2}\right)$. Error bars show \pm standard deviation from three replicate samplings. Note that collections were not made in 1987 nor between 1991 and 1997. 
A complete list of the benthic species found at the Palo Alto site in the year 2019 is shown in appendix 8. The benthic species name changes (as of 2019) for the species listed in appendix 8 are shown in appendix 9 .

A sudden drop in animal abundance was observed in February 2008 (figs. 12,13). Very few animals were found at the Palo Alto site, and the mudflat community was evidently stressed by some event between the January and February sampling. Possible causes of the stress include sedimentation or freshwater inundation. There was a large storm on January 25,2008 , with rainfall rates exceeding 0.5 centimeters per hour for more than half the day, including during the low-tide period. No obvious changes in the sediment surface were observed, but sediment changes can occur and be incorporated quickly in this tidal environment. Other possible causes of benthic community death or exodus include a toxic event or anoxia. It is unlikely that either of these occurred, because L. petalum were present in the deep sediment in February 2008, and other taxa were found again in March. This would not happen with toxicity or anoxia. The timeline for recovery from anoxia can be estimated based on observations following an anoxic event at this site in 1975. Macroalgae were deposited on the mudflat surface and began to decay, and the resulting bacterial consumption of oxygen led to anoxia. The benthic community took many months to recover from this anoxic event. Animals that returned after the disturbance in 2008 include those species with pelagic larvae and mobile adults, as would be expected. Nonmobile brooders returned to the site in 2009, concurrent with an increase in abundance of the brooding clam G. gemma and the brooding polychaete $S$. benedicti. This trend continued into the present (2019) when brooder species were nearly half of the top 10 most abundant species, whereas oviparous and spawner species made up the rest.

Multivariate analyses of population data of the dominant species with environmental parameters did not reveal any relations, except with the concentration of silver and copper in the sediment and in the tissue of L. petalum (using data reported by David and others, 2002). Therefore, this update will consider only those metals. Metal concentration and abundance of species with the most susceptible mode of feeding and reproduction will be compared over the period of the study. One such susceptible species, the worm $H$. filiformis, increased in abundance with the decrease in silver and copper until 2008 (fig. 21). This was of interest because $H$. filiformis is a burrowing deposit feeder and, thus, has continuous internal and external tissue contact with the sediment. In addition, this is one of the few species in the present community that reproduces exclusively by laying eggs in the sediment. The larvae hatch after 2 or 3 days and experience a very short planktonic period ( $2-3$ days) before settling back to the mud as juvenile worms (Rasmussen, 1956). The short planktonic period limits the species' speed of expansion into new areas. We hypothesize that once a few individuals successfully arrived at the study site, $H$. filiformis increased in abundance because either the adult worms or the eggs found the environment agreeable. This species is not likely to move into an area quickly after an environmental stressor because of its mode of reproduction and short planktonic larval period. A large spike in $H$. filiformis abundance was observed in January 2008 because of the settling of larvae, but these larvae did not survive the event that occurred before the February sampling. So far, the species has not returned in high numbers to the study site. The dynamics of recovery for this species will continue to be monitored closely.

Two species have shown the opposite trend of H. filiformis. The crustacean A. abdita (fig. 17) and the worm $S$. benedicti (fig. 18) have declined in abundance coincident with the decline in metals. These species have very similar life-history characteristics that make them less susceptible to high silver and copper concentrations in sediment. In contrast with the burrowing lifestyle of $H$. filiformis, both species live on the surface of the sediment in tubes that are built from sediment particles. Rather than feeding on the mud, they filter particles suspended in the water column or settled on the sediment surface. Instead of laying eggs in the mud, they brood their young and produce young that are capable of either swimming or settling upon hatching. These opportunistic characteristics make these species ideal for invading a disturbed or stressed environment; thus, they are capable of rapid increase in population size and distribution. It is not surprising that both species immediately responded to the near-empty community in February 2008 and have subsequently declined (figs. 17, 18). This abundance pattern is consistent with expectations for an opportunistic species, confirming both their tolerance to elevated metals and their inability to out-compete less opportunistic diverse communities in nonstressed conditions.

Other species share the characteristics highlighted in our discussion of $H$. filiformis, $S$. benedicti, and $A$. abdita. The species with similar characteristics have been combined into plots that examine the percentage of abundance represented by each feeding and reproductive mode (figs. 23-26). Each characteristic reproductive and feeding mode are shown as average percentages for the month of August (figs. 23-26) because natural spatial variability (that is, the large standard deviations around the monthly means) and seasonal variability of invertebrate abundance can be quite large. To interpret these plots, the life-history characteristics must first be examined to determine if there is some mechanism by which this organism could be responding to a decrease in silver or copper in the environment. It is likely that silver, but probably not copper, adversely affected reproduction of all animals (Hornberger and others, 2000). If species with pelagic larvae were transported into the area, they did not survive to dominate the community. Species having both oviparous and mixed (that is, species capable of oviparity and brooding) reproductive modes (Ahn and others, 1995; Hornberger and others, 2000) are worth examining in more detail. The gradual increase in abundance of this group through 1983 occurred concurrently with the gradual reduction of metals in the environment during that 
time. In the present environment, with much lower metal concentrations, these species respond to a different variety of stresses, and the percentage of brooding and oviparous individuals in the community reflects those stresses (figs. 23, 24). Although the percentage is variable, the number of brooders plus oviparous individuals has never been as high as it was in the early 1970s. We interpret this as being a reflection of the general health of the benthic environment. In a similar manner, we can examine the feeding modes of most of the individuals (figs. 25, 26). High silver and (or) copper concentrations in the sediment are unlikely to be healthy for species that ingest sediment in order to consume the interstitial and attached carbon; thus, it is reasonable to expect species that consume particles from the water column to be more protected from the contaminants in the sediment. Filterfeeding species are usually the dominant group throughout the dataset, and the subsurface-deposit feeders are the group that shows the largest increase in dominance after the 1970s. This is consistent with the conceptual model posed here.

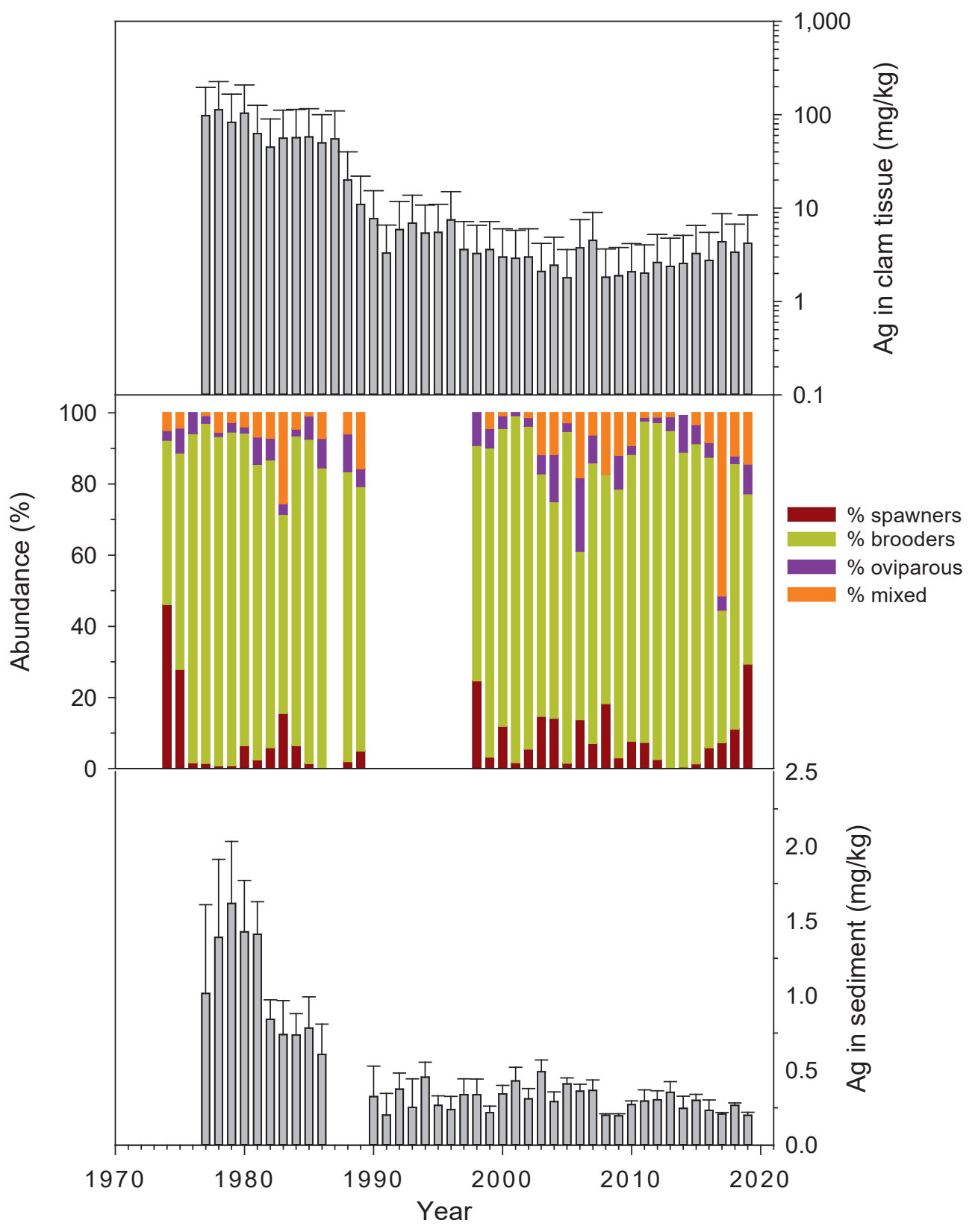

Figure 23. Graphs showing reproductive-mode annual abundances for top-10-ranked species (middle), as well as silver (Ag) concentrations in clam Limecola petalum (top) and in sediment (bottom), at Palo Alto, Calif., site, 1974-2019. Concentrations are grand mean \pm standard error, in milligrams per kilogram $(\mathrm{mg} / \mathrm{kg}$ ). Abundance data (in percent [\%]) for each year is from August of that year (note that no collections were made in 1987 nor between 1991 and 1997). Reproductive modes: brooder, broods young and release juveniles as fully functional "miniature adults"; mixed, capable of ovipary and brooding; oviparous, lays eggs in or on sediment; spawner, releases gametes into water column and juveniles settle out of plankton onto sediment surface after growth in plankton. 


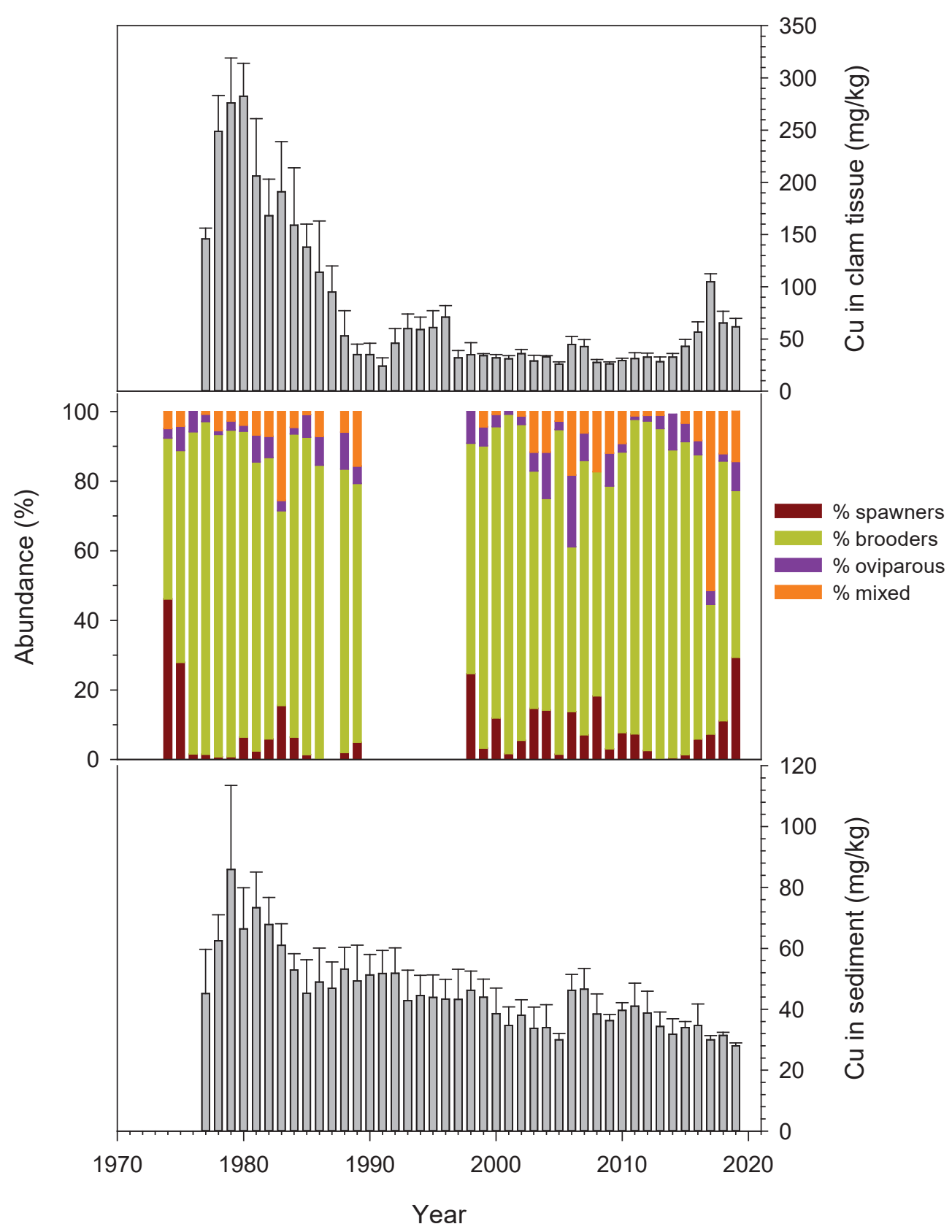

Figure 24. Graphs showing reproductive-mode annual abundances for top-10-ranked species (middle), as well as copper (Cu) concentrations in clam Limecola petalum (top) and in sediment (bottom), at Palo Alto, Calif., site, 1974-2019. Concentrations are grand mean \pm standard error, in milligrams per kilogram $(\mathrm{mg} / \mathrm{kg}$ ). Abundance data (in percent [\%]) for each year is from August of that year (note that no collections were made in 1987 nor between 1991 and 1997). Reproductive modes: brooder, broods young and release juveniles as fully functional "miniature adults"; mixed, capable of ovipary and brooding; oviparous, lays eggs in or on sediment; spawner, releases gametes into water column and juveniles settle out of plankton onto sediment surface after growth in plankton. 


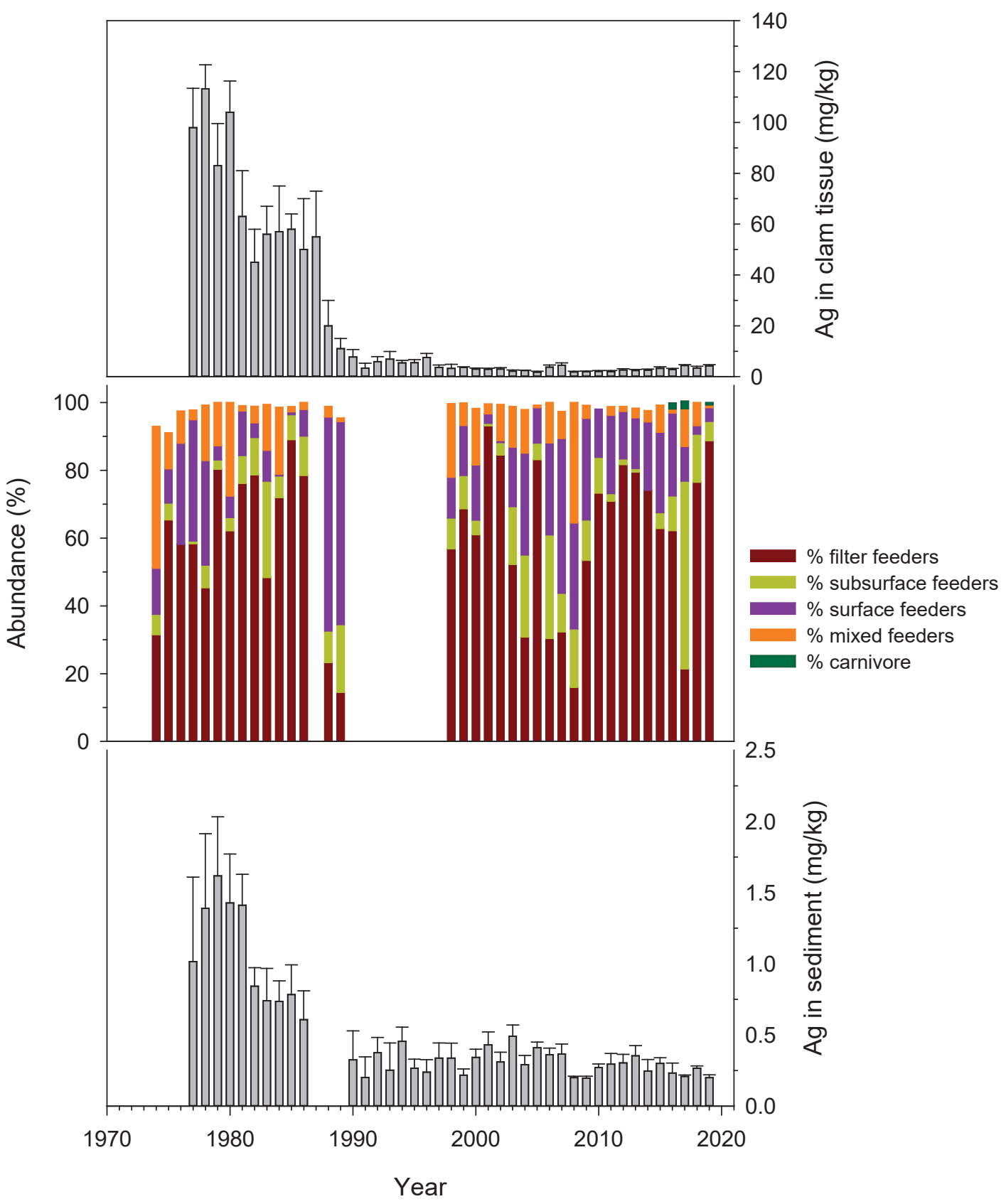

Figure 25. Graphs showing feeding-mode annual abundances for top-10-ranked species (middle), as well as silver (Ag) concentrations in clam Limecola petalum (top) and in sediment (bottom), at Palo Alto, Calif., site, 1974-2019. Concentrations are grand mean \pm standard error, in milligrams per kilogram (mg/kg); no data were collected in sediment in 1987-1989. Abundance data (in percent [\%]) for each year is from August of that year (note that no collections were made in 1987 nor between 1991 and 1997). Feeding modes: carnivore, preys on other infaunal invertebrates; filter, filters food particles from water column; mixed, capable of filter feeding and surfacedeposit feeding; subsurface deposit, ingests subsurface sediment and removes food from sediment in gut; surface deposit, ingests food particles on surface sediment. 


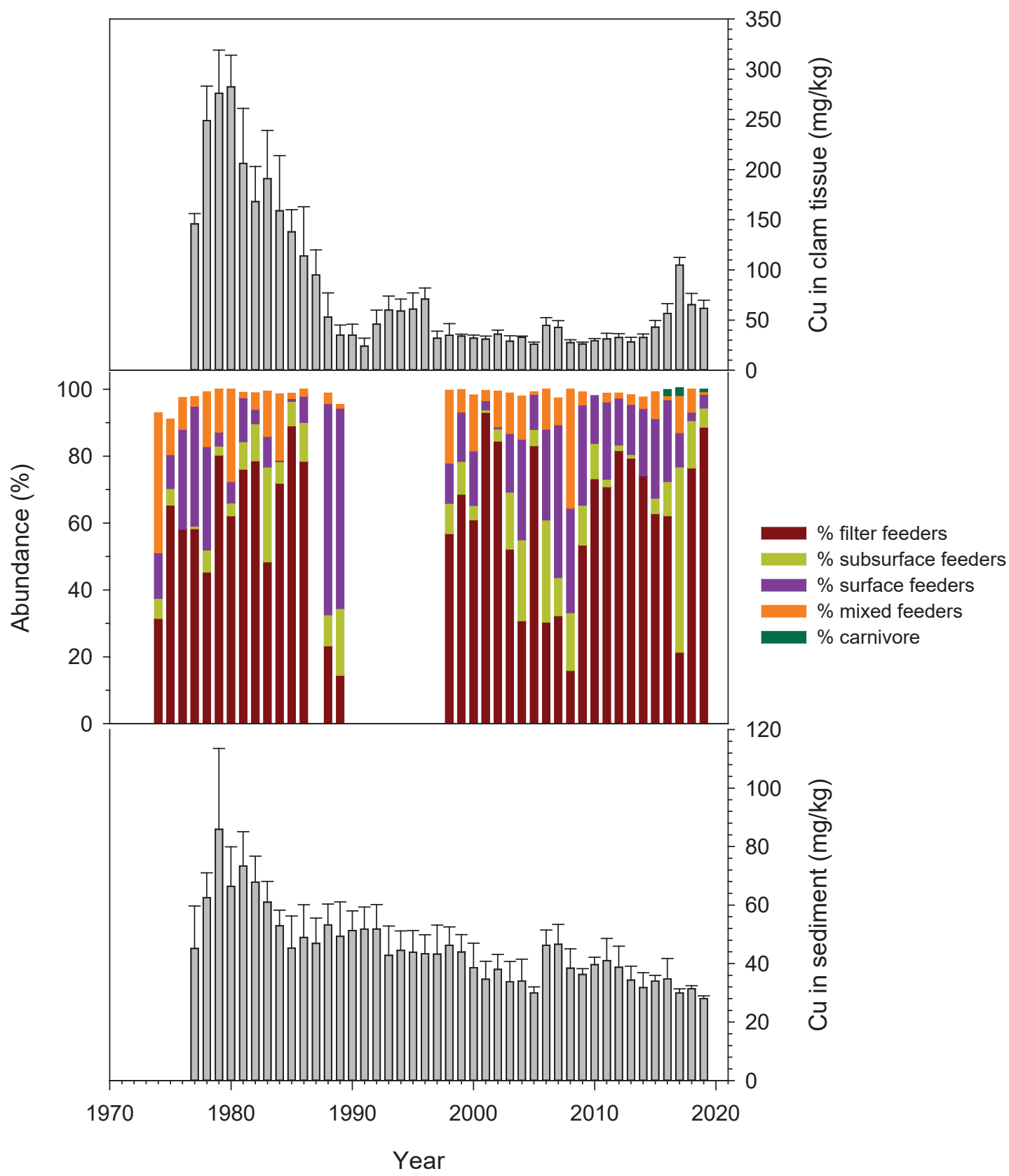

Figure 26. Graphs showing feeding-mode annual abundances for top-10-ranked species (middle), as well as copper (Cu) concentrations in clam Limecola petalum (top) and in sediment (bottom), at Palo Alto, Calif., site, 1974-2019. Concentrations are grand mean \pm standard error, in milligrams per kilogram $(\mathrm{mg} / \mathrm{kg}$ ). Abundance data (in percent [\%]) for each year is from August of that year (note that no collections were made in 1987 nor between 1991 and 1997). Feeding modes: carnivore, preys on other infaunal invertebrates; filter, filters food particles from water column; mixed, capable of filter feeding and surface-deposit feeding; subsurface deposit, ingests subsurface sediment and removes food from sediment in gut; surface deposit, ingests food particles on surface sediment. 
The change in function of the benthic community over time can be examined by ranking the top 10 species by abundance and plotting the $\log (\mathrm{n}+1)$ of mean abundance against the rank of each species (Whittaker, 1965). The plots for 2016-2019 (fig. 27) are indicative of a healthy benthic community, with species dominance, as revealed by abundance, not showing large differences among the top 10 species. An examination of similar plots for August of three hydrologically dry years during this study $(1977,1989$, and 2002) shows that the shape of the curve has changed greatly and that the 2019 curve is most similar to that seen in 2002 (fig. 28). The figure shows a community that was, with the rest of the species having similar abundances, heavily dominated by three species in 1977 and 1989 versus a community with one dominant species in 2002 and 2019. G. gemma is the most dominant species in all years except 1989. However, the 2019 graph does not show as smooth of a downward slope as have curves from recent years, which display a slightly less homogenized decrease in species abundance (fig. 27). The 1977 community plot is the most extreme, with three species dominating the community and the remainder having similar but relatively low abundances.
It is informative to examine the rank-abundance plots within the context of the life-history characteristics of each species. If shifts in plot shape coincide with a shift in community structure and function, that might be indicative of a healthier environment. Two critical life-history characteristics are shown: feeding mode (fig. 29) and reproductive mode (fig. 30). The 1977 community was dominated by filter feeders (species that consume particles in the water column) and mixed feeders (species that have the option of either filter feeding or feeding on the sediment surface), as well as two species that feed on food particles on the sediment surface (fig. 29). In 1989, the species composition had shifted such that filter-feeding, subsurfacedeposit-feeding, and surface-deposit-feeding species (that is, those that ingest sediment and strip the food off the sediment in their gut) dominated the community. In 2002, a shift was observed towards species that were mixed and subsurfacedeposit feeders. The most recent data (2019) show the community to be similar to that of 1989 , with the composition having shifted to that of filter-feeding species, subsurfacedeposit-feeding species, and mixed-feeding species. During the period of this study, a shift has occurred from a community

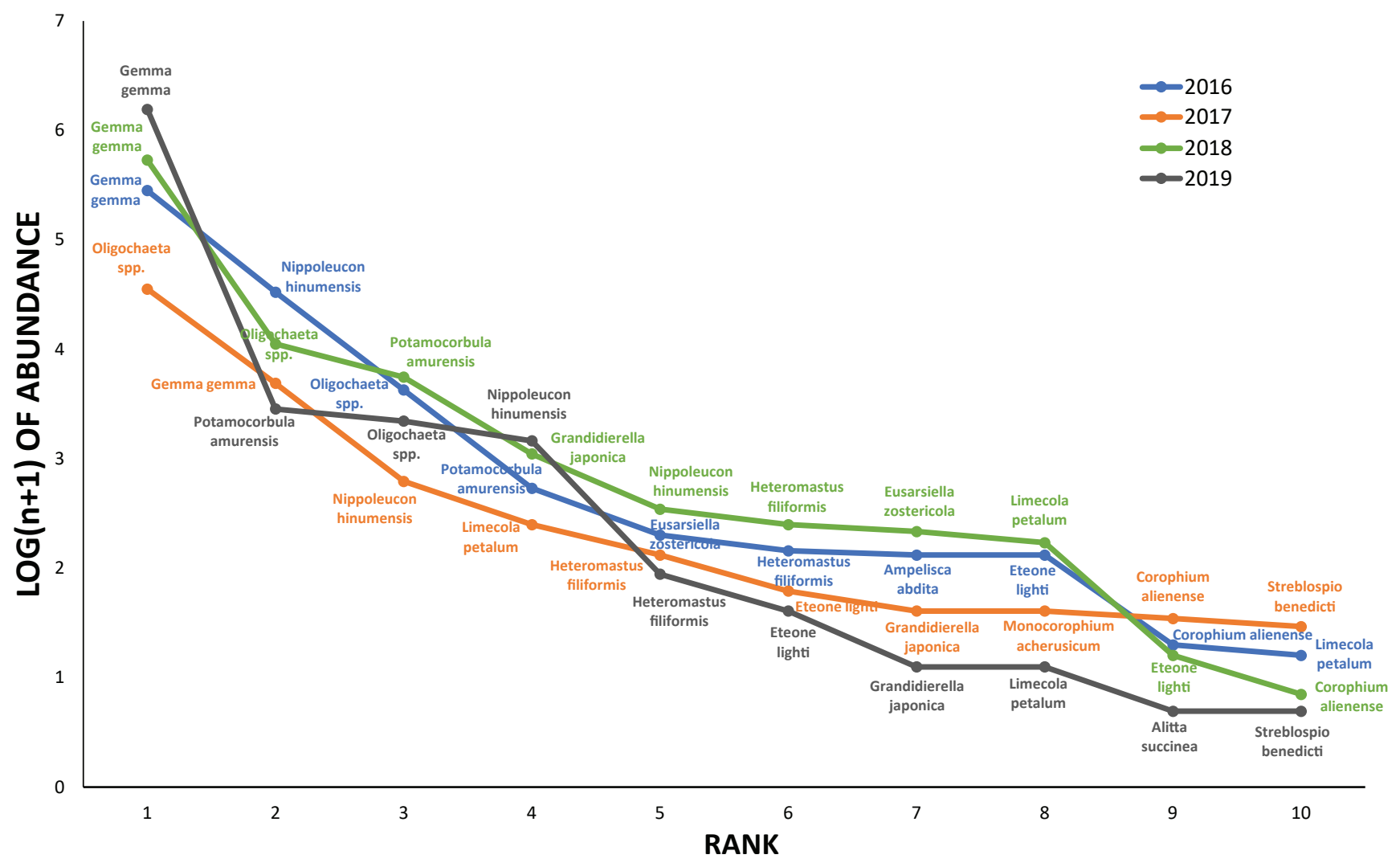

Figure 27. Plots showing species rank-abundances for benthic community at Palo Alto, Calif., site, 2016-2019. 


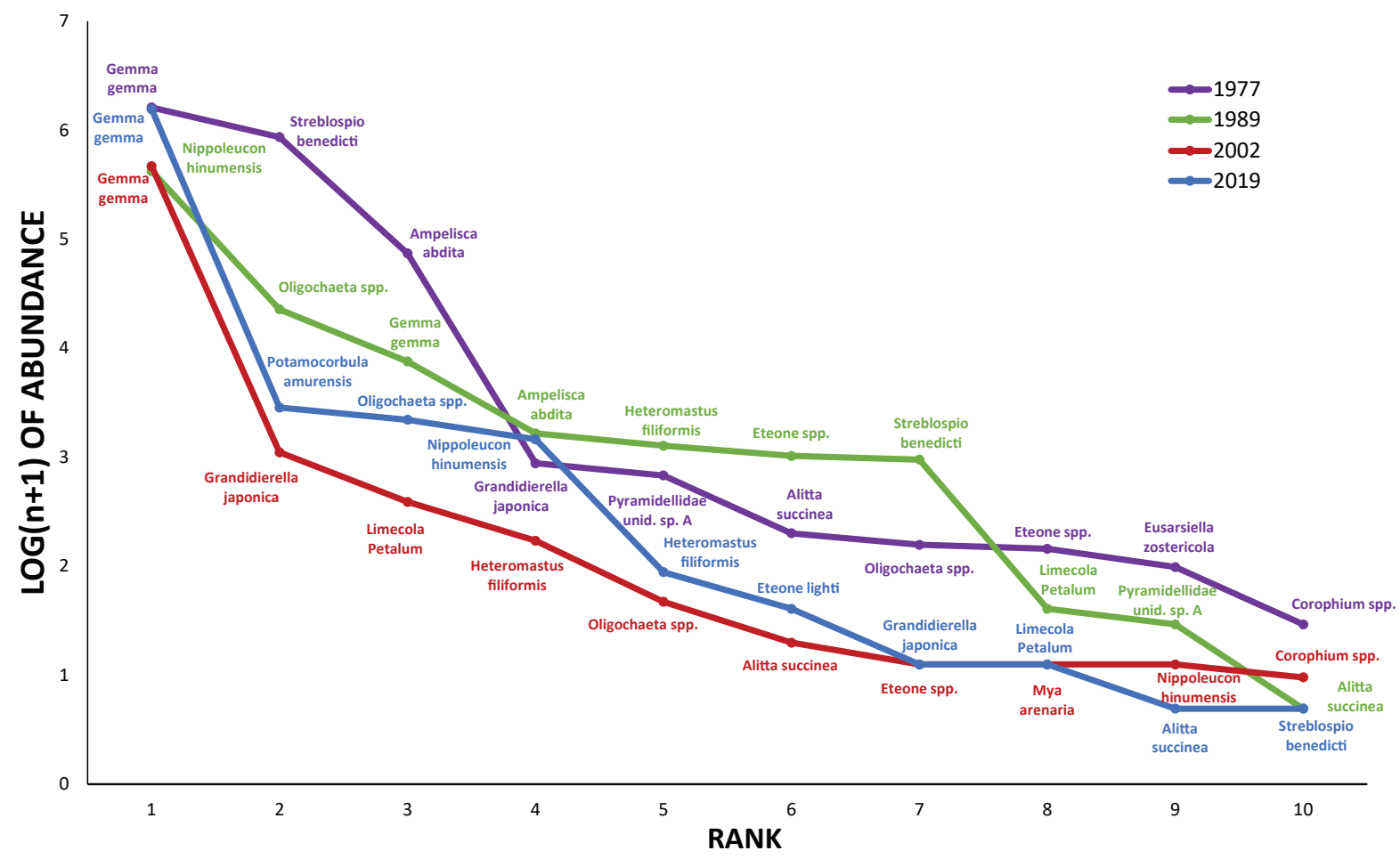

Figure 28. Plots showing species rank-abundances for benthic community at Palo Alto, Calif., site, for years 1977, 1989, 2002, and 2019.

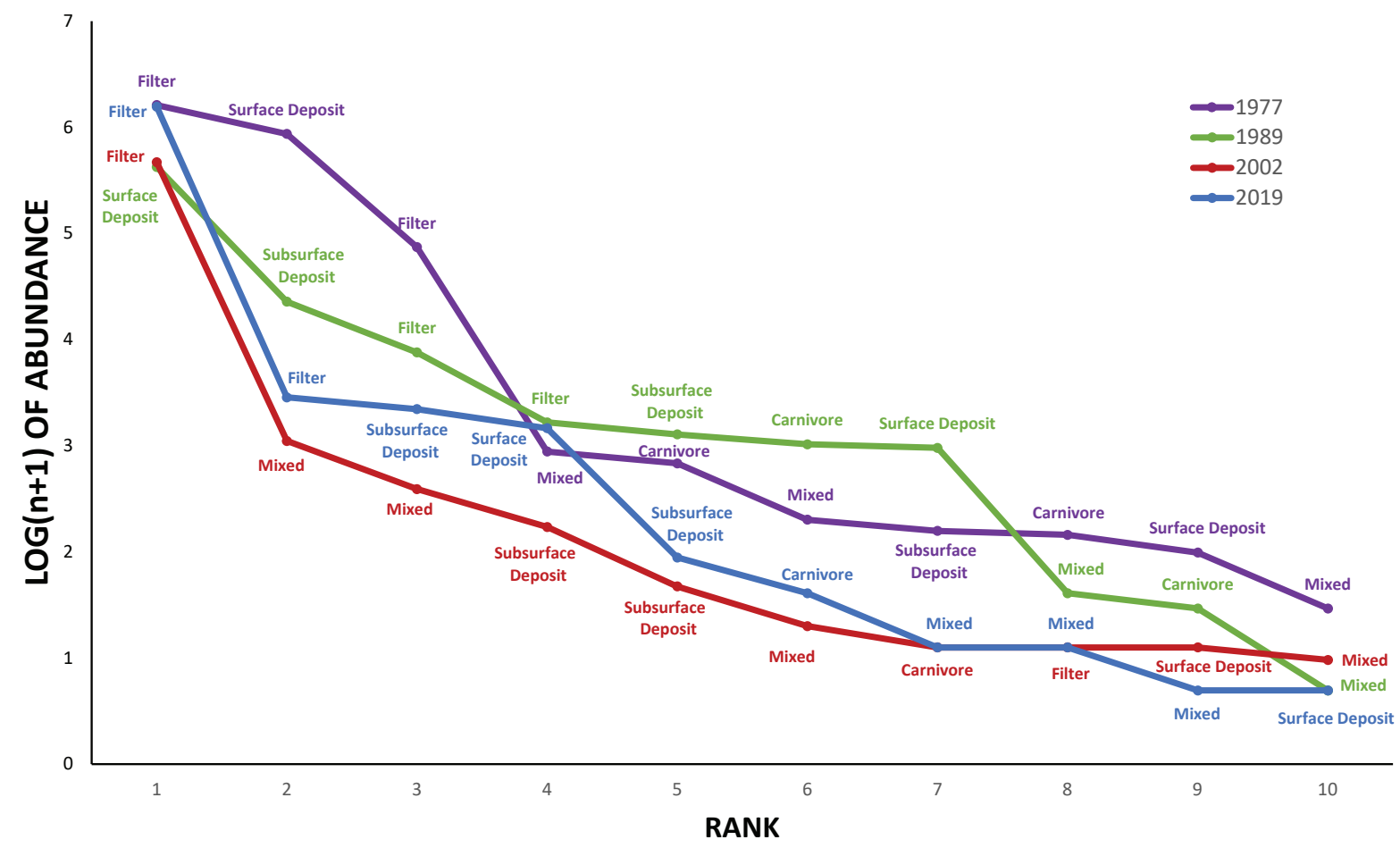

Figure 29. Plots showing rank-abundances identified by feeding modes of same benthic-community species shown in figure 28, at Palo Alto, Calif., site, for years 1977, 1989, 2002, and 2019. Feeding modes: carnivore, predator on other fauna; filter, filters food particles from water column; mixed, capable of filter feeding and surface-deposit feeding; subsurface deposit, ingests subsurface sediment and removes food from sediment in gut; surface deposit, ingests food particles on surface sediment. 


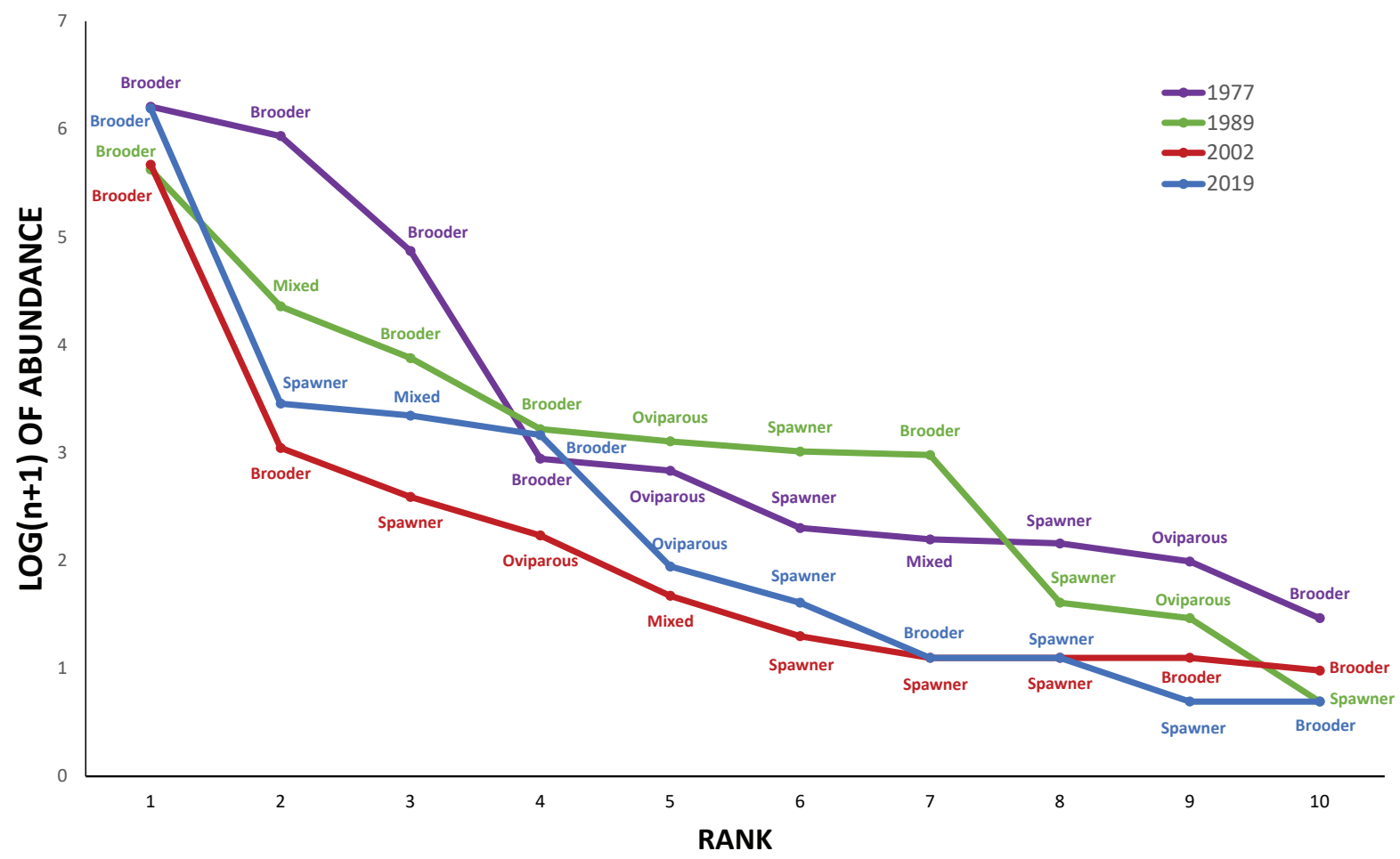

Figure 30. Plots showing rank-abundances identified by reproductive modes of same benthic-community species shown in figure 28, at Palo Alto, Calif., site, for years 1977, 1989, 2002, and 2019. Reproductive modes: brooder, broods young and release juveniles as fully functional "miniature adults"; mixed, capable of ovipary and brooding; oviparous, lays eggs in or on sediment; spawner, releases gametes into water column and juveniles settle out of plankton onto sediment surface after growth in plankton.

dominated by species that feed either in the water column or on recently settled food particles on the sediment surface to a mixed community of species that feed directly on the subsurface sediment, those that are capable of feeding in the water column, and those that feed on the sediment surface. The species that returned following the defaunation event in January and February 2008 have maintained this pattern. Thus, it is unlikely that any sediment-borne pollutant caused the collapse of the community in early 2008.

An examination of these rank-abundance plots using reproductive mode as the descriptor for each point is equally informative (fig. 30). The dominant species in 1977 were species that brood their young and release fully functional juveniles into the environment. In 1989, there were still several brooders, but there were also two species that lay their eggs in the sediment. Although brooding species remain the most abundant species for all years, species that spawn their gametes into the water column - in combination with those that lay eggs in the sediment (oviparous) - have an equal presence. It is possible that some of the metal contaminants found in the sediment in the 1970s at this location limited the success of species that consumed the sediment for food, laid eggs in the sediment, or depended on water-borne larvae to repopulate the community. Interestingly, at present (2019) the reproductive mode of most species is brooding with some mixed egg laying (oviparous) and spawning species (fig. 30).

\section{Summary}

\section{Long-Term Observations}

Since 1974, U.S. Geological Survey (USGS) personnel have monitored and conducted basic research on the benthic sediments and biological community in the vicinity of the discharge of the Palo Alto Regional Water Quality Control Plant (PARWQCP). The time series presented here updates and extends previous findings (for example, Luoma and others, 1991, 1995a, 1996; Hornberger and others, 2000; Thompson and others, 2002; Shouse and others, 2003, 2004; Moon and others, 2005; Cain and others, 2006; Dyke and others, 2012, 2014) with additional data from January 2019 through December 2019 to create a record spanning more than 40 years. This long-term dataset includes sediment chemistry and tissue concentrations of metals (1977-2019 for copper and silver; 1994-2019 for other metals), condition index (CI) (1988-2019), and reproductive activity in Limecola petalum and population dynamics of benthic invertebrate species (1974-2019). The time series encompasses the period when high concentrations of copper and silver were present in sediment and L. petalum (1970s and early 1980s) and the subsequent period when those concentrations declined. The sustained record of biogeochemical data at this site provides a 
rare opportunity to examine the biological response to metal contamination within this ecosystem over multiple time scales.

Studies during the 1970 s showed that sediments and L. petalum at the Palo Alto site contained highly elevated levels of metals, especially silver and copper, as a result of metal-containing effluent being discharged from the PARWQCP to the south San Francisco Bay. In the early 1980s, the point-source metal loading from the nearby PARWQCP was significantly reduced as a result of advanced treatment of influent and source mitigation. Coincident with declines in metal loadings, concentrations of metals in the sediment and in the clam L. petalum (serving as a biomonitor of metal exposures) also declined, as previously described by Hornberger and others (2000). Interannual trends in clams and sediments were highly correlated with copper loadings from PARWQCP (concurrent loading data for silver were not available). Metal levels in sediments and clams responded relatively quickly to changes in metal loading; the reduction in metal loadings by the PARWQCP resulted in a reduction in metal concentrations in both the sediment and L. petalum within a year (Hornberger and others, 2000).

Biological responses to metal inputs to south San Francisco Bay were assessed at different levels of organization. These responses are interpreted within the appropriate temporal context. Because metal exposures were already high when the study began, interpretations are based on observed changes in biological attributes as metal inputs declined. In general, discernable responses at the organism level (that is, reproductive activity, a manifestation of a cellular or physiological change) to metal exposure may occur within a relatively short time (for example, at intra-annual and interannual time scales, as previously exposed individuals recover and successive cohorts become established), whereas population- and community-level responses take longer to develop. Stable changes in the benthic community may take a relatively long period of time to be expressed because of the normally high degree of intra-annual variability of benthic community dynamics, which reflects the cumulative response to natural and anthropogenic disturbances. It is, therefore, critical that sampling frequency and duration be conducted at temporal scales appropriate to characterize the different biological responses.

During the first 10 years of this study, when the metal concentrations were initially high and declining, the benthic community was largely dominated by nonindigenous, opportunistic species. This dominance was initially attributed to their ability to survive the many physical disturbances on the mudflat (Nichols and Thompson, 1985a, b), for example, sediment erosion and deposition, and aerial exposure at extreme low tides. The possible effects of metal exposure as a disturbance factor were not considered in the analyses by Nichols and Thompson $(1985 \mathrm{a}, \mathrm{b})$ because the decline in metal concentrations in L. petalum and sediment had just begun.

However, biological responses throughout the period of declining metal exposure emerged. Reproductive activity improved within a year or two of reduced metal exposure
(Hornberger and others, 2000), and responses at the population and community levels were observed afterward. Identification of these responses was possible because the frequency of sampling allowed long-term trends related to metal contamination to be identified within the context of repeating seasonal cycles and unrelated intra-annual variation.

The ecology of the Palo Alto mudflats is part of the larger south San Francisco Bay, which has been undergoing some changes in recent years. During 1999-2005, USGS scientists noticed an increase in phytoplankton biomass in the southern bay. Sampling in the deeper water of the southern bay showed that bivalves were mostly absent from the system during this increase in primary production. Cloern and others (2007) indicated that the cause of the decline in bivalves was an increase in fish predators resulting from increased offshore upwelling activity. The higher reproductive success of demersal fish, crabs, and shrimp during this period resulted in a higher number of juveniles moving into the south San Francisco Bay to grow. Since 2005, scientists have seen the large bivalve populations fluctuate more than in previous decades, and these fluctuations have been reflected in changes in phytoplankton biomass in the system (primarily through an increase in phytoplankton biomass in late summer and fall). The value of these findings in the greater south San Francisco Bay to this study is two-fold. First, it reinforces the importance of the benthic community's impact on ecosystem function and solute cycling. Second, it shows that the high intertidal community at the Palo Alto site has not been demonstrably affected by these greater south San Francisco Bay influences during these years. These findings reinforce our confidence that the changes observed in the benthic community are in large part owing to local factors.

\section{Observations}

Throughout 2019, copper and silver concentrations in sediments remained representative of the concentrations observed since 1990, after the significant reductions in concentrations during the 1980s that coincided with reductions in the discharge of these elements from PARWQCP. Since 1994, annual mean copper and silver concentrations have fluctuated modestly. Copper concentrations, as well as iron and zinc concentrations, have declined slightly over that period, whereas silver concentrations have not. Sedimentary concentrations of other elements have varied from year to year but shown no sustained temporal trend.

Most metal concentrations in L. petalum during 2019 are comparable to the concentrations observed since the 1990s. Mercury concentrations observed in 2019 were essentially unchanged from 2018 and remained high relative to the long-term record. Regression analysis indicated that the interannual variation in silver and zinc were partly dependent on the condition index, a metric of the physiological condition of the clam. In contrast, the variation of other metals appeared to be independent of the CI and sediment metal 
concentrations. Evidence of a temporal trend in the data over the period 1994-2019 is absent for all metals.

The long-term data series suggest that contemporary metal concentrations in sediments and tissue of $L$. petalum likely reflect a combination of factors. These may include inputs from the PARWQCP and other south San Francisco Bay point sources, inputs from local streams and stormwater conveyances, cycling of contaminants stored within bay sediments, and regionally scaled physical and biogeochemical processes controlling the distribution and bioavailability of metals.

The long-term dataset that we augment with this report demonstrates various adverse effects of contaminants on benthic organisms. Decreasing particulate concentrations of trace metals in the local environment have benefited resident populations of invertebrates, as shown by increased reproductive activity in L. petalum that has been sustained through the present (2019). In early 2008, the benthic community declined, with few animals present in February. This decline was likely the result of a natural stressor, such as a sedimentation or freshwater inundation event, and the composition of the benthic community supports that supposition. Mobile animals such as L. petalum that were capable of burrowing down to avoid the stressor probably did so, but many other species either relocated or did not survive at the study site. This natural disturbance gives scientists the opportunity to observe mudflat community recovery from a natural stressor and to compare this recovery to that observed during the long-term decline of metals in sediment and L. petalum. Shifts in species abundance at the study site have been interpreted to be a response to decreasing sediment contaminants within two years of improved wastewater treatment at PARWQCP. These community changes have included a shift from species that live on the surface, filter food out of the water column, or consume particles on the sediment surface and brood their young to a community dominated by species that live on and below the surface, consume the sediment directly to harvest food particles, and spawn and lay eggs in the sediment. Hence, the benthic community now has a greater dependence on sediment for food and reproduction relative to the late 1970s, consistent with management practices that have improved sediment quality. The 2008-2019 data reveal a community that had a short-term physical stressor but not one that was subject to trace-metal contamination. At present (2019), the species abundance data continue to show signs of a community that has recovered and stabilized, and the constancy of functional groups reflects the stability of the ecosystem. Thus, the data from the recent record (that is, within the three decades prior to 2019) reflect the improved ecological condition of the Palo Alto site, which appears indicative of an integrated regional ecological baseline. This "natural experiment" has given USGS scientists an opportunity to test various hypotheses on the benthic community response to different stressors. Future data will continue to refine the understanding of the response of this benthic community to natural and anthropogenic stressors.

\section{Value of Long-Term Monitoring}

This study highlights the importance of long-term ecosystem monitoring. Although monitoring studies cannot always unambiguously determine the causes of variation in metal concentrations or benthic community structure, time-series data may reveal ecological responses that are distinctively associated with human activities. Changes and trends in community structure that may be related to anthropogenic stressors, as was seen in this study for multiple trace metals, can be established only with a concerted and committed sampling effort of sufficient duration and frequency and data interpretation. The strength and uniqueness of this study is the integrated analysis of metal exposure and biological response at intra-annual and interannual time scales over multiple decades.

Human activities have and will continue to change south San Francisco Bay and its watershed. Factors that may influence metals in the near and long term include climate variation, non-point-source runoff and efforts to mitigate it, reconnection of reclaimed intertidal areas to the bay, cycling of legacy contamination within the bay, new and redevelopment of the Bay Area landscape, and sea-level rise. Among emerging contaminants of concern are metal-based nanomaterials, many of which include metal-based products in forms that environmental scientists and regulators have little or no experience with. Quantitative descriptions of the bioavailability of trace metals from such sources have only recently been reported (for example, Croteau and others, 2011, 2014). The long-term, detailed, integrated ecological baseline that has been established at this sampling site will be uniquely valuable in assessing the response of the environment and informing management and regulatory agencies as human activities within the watershed continue.

\section{References Cited}

Ahn, I.Y., Kang, Y.C, and Choi, J.W., 1995, The influence of industrial effluents on the intertidal benthic communities in Panweol, Kyeonggi Bay (Yellow Sea) on the west coast of Korea: Marine Pollution Bulletin, v. 30, p. 200-206, https://doi.org/10.1016/0025-326X(94)00125-S.

Alpine, A.E., and Cloern, J.E., 1992, Trophic interactions and direct physical effects control phytoplankton biomass and production in an estuary: Limnology and Oceanography, v. 37, p. 946-955, https://doi.org/10.4319/1o.1992.37.5.0946. 
Cain, D.J., Croteau, M.-N., Parchaso, F., Stewart, R., Thompson, J.K., Zierdt Smith, E.L., Kieu, L., Turner, M., and Baesman, S.M., 2021, Data for monitoring trace metal and benthic community near the Palo Alto Regional Water Quality Control Plant in south San Francisco Bay, California: U.S. Geological Survey data release, https://doi.org/10.5066/P9IBQ23S.

Cain, D.J., and Luoma, S.N., 1990, Influence of seasonal growth, age and environmental exposure on $\mathrm{Cu}$ and $\mathrm{Ag}$ in a bivalve indicator, Macoma balthica in San Francisco Bay: Marine Ecology Progress Series 60, p. 45-55.

Cain, D.J., Parchaso, F., Thompson, J.K., Luoma, S.N., Lorenzi, A.H., Moon, E., Shouse, M.K., Hornberger, M.I., and Dyke, J.L., 2006, Near-field receiving water monitoring of trace metals and a benthic community near the Palo Alto Regional Water Quality Control Plant in south San Francisco Bay, California-2005: U.S. Geological Survey Open-File Report 2006-1152, 128 p., https://doi.org/10.3133/ofr20061152.

Childress, C.J.O., Foreman, W.T., Connor, B.F., and Maloney, T.J., 1999, New reporting procedures based on long-term method detection levels and some considerations for interpretations of water-quality data provided by the U.S. Geological Survey National Water Quality Laboratory: U.S. Geological Survey Open-File Report 99-193, 19 p., https://doi.org/10.3133/ofr99193.

Cloern, J.E., Jassby, A.D., Thompson, J.K., and Hieb, K., 2007, A cold phase of the east Pacific triggers new phytoplankton blooms in San Francisco Bay: Proceedings of the National Academy of Science, v. 104, no. 47, p. 18,561-18,565, https://doi.org/10.1073/pnas.0706151104.

Cohen, A.N., and Carlton, J.T., 1995, Biological study, nonindigenous aquatic species in a United States estuary-A case study of the biological invasions of the San Francisco Bay and Delta: Washington, D.C., Report for the U.S. Fish and Wildlife Service and the National Sea Grant College Program, Connecticut Sea Grant, accessed July 12, 2019, at https://www.scribd.com/document/106882160/ Cohen-Carlton-1995-San-Francisco-Bay-Invasion-Report\#.

Croteau, M.-N., Misra, S.K., Luoma, S.N., and ValsamiJones, E., 2011, Silver bioaccumulation dynamics in a freshwater invertebrate after aqueous and dietary exposures to nanosized and ionic Ag: Environmental Science and Technology, v. 45, p. 6660-6607, https://doi.org/10.1021/ es200880c.

Croteau, M.-N., Misra, S.K., Luoma, S.N., and ValsamiJones, E., 2014, Bioaccumulation and toxicity of $\mathrm{CuO}$ nanoparticles by a freshwater invertebrate after waterborne and dietborne exposures: Environmental Science and Technology, v. 48, p. 10,929-10,937, https://doi.org/ 10.1021/es5018703.
David, C.P.C., Luoma, S.N., Brown, C.L., Cain, D.J., Hornberger, M.I., and Lavigne, I.R., 2002, Near field receiving water monitoring of trace metals in clams (Macoma balthica) and sediments near the Palo Alto Water Quality Control Plant in south San Francisco Bay, California-1999-2001: U.S. Geological Survey Open-File Report 2002-453, 105 p., https://doi.org/10.3133/ofr02453.

Dyke, J.L., Cain, D.J., Thompson, J.K., Kleckner, A.E., Parchaso, F., Hornberger, M.I., and Luoma, S.N., 2014, Near-field receiving water monitoring of trace metals and a benthic community near the Palo Alto Regional Water Quality Control Plant in south San Francisco Bay, California-2013: U.S. Geological Survey OpenFile Report 2014-1174, 81 p., https://doi.org/10.3133/ ofr 20141174 .

Dyke, J.L., Thompson, J.K., Cain, D.J., Kleckner, A.E., Parchaso, F., Luoma, S.N., and Hornberger, M.I., 2012, Near-field receiving water monitoring of trace metals and a benthic community near the Palo Alto Regional Water Quality Control Plant in south San Francisco Bay, California-2011: U.S. Geological Survey OpenFile Report 2012-1165, 108 p., https://doi.org/10.3133/ ofr20121165.

Elrick, K.A., and Horowitz, A.J., 1985, Analysis of rocks and sediments for arsenic, antimony, and selenium, by wet digestion and hydride generation atomic absorption: U.S. Geological Survey Open-File Report 85-497, 14 p., https://doi.org/10.3133/ofr85497.

Förstner, U., and Wittmann, G.T.W., 1979, Metal pollution in the aquatic environment: Berlin, Germany, Springer-Verlag, https://doi.org/10.1002/jobm.19810210712.

Glaser, J.A., Foerst, D.L., Mckee, G.D., Quave, S.A., and Budde, W.L., 1981, Trace analyses for wastewaters: Environmental Science and Technology, v. 15, no. 12, p. 1426-1435, https://doi.org/10.1021/es00094a002.

Hook, S.E., and Fisher, N.S., 2001, Sublethal effects of silver in zooplankton-Importance of exposure pathways and implications for toxicity testing: Environmental Toxicology and Chemistry, v. 20, no. 3, p. 568-574, https://doi.org/ 10.1002/etc.5620200316.

Hook, S.E., and Fisher, N.S., 2002, Relating the reproductive toxicity of five ingested metals in calanoid copepods with sulfur affinity: Marine Environmental Research, v. 53, no. 2, p. 161-174, https://doi.org/10.1016/S0141-1136(01)001180 .

Hornberger, M.I., Luoma, S.N., Cain, D.J., Parchaso, F., Brown, C.L., Bouse, R.M., Wellise, C., and Thompson, J.K., 2000, Linkage of bioaccumulation and biological effects to changes in pollutant loads in south San Francisco Bay: Environmental Science and Technology, v. 34, no. 12, p. 2401-2409, https://doi.org/10.1021/es991185g. 
Hornberger, M.I., Luoma, S.N., van Geen, A., Fuller, C., and Anima, R., 1999, Historical trends of metals in the sediments of San Francisco Bay, California: Marine Chemistry, v. 64, p. 39-55, https://doi.org/10.1016/S03044203(98)80083-2.

Kennish, J.K., 1998, Pollution impacts on marine biotic communities: New York, CRC Press, 310 p.

Kleckner, A.E., Kakouros, E., and Stewart, A.R., 2017, A practical method for the determination of total selenium in environmental samples using isotope dilution-hydride generation-inductively coupled plasma-mass spectrometry: Limnology and Oceanography Methods, v. 15, no. 4, p. 363-371, https://doi.org/10.1002/lom3.10164.

Long, E.R., MacDonald, D.D., Smith, S.L., and Calder, F.D., 1995, Incidence of adverse biological effects within ranges of chemical concentrations in marine and estuarine sediments: Environmental Management, v. 19, p. 81-97, https://doi.org/10.1007/BF02472006.

Luoma, S.N., Cain, D.J., Brown, C., and Axtmann, E.V., 1991, Trace metals in clams (Macoma balthica) and sediments at the Palo Alto mudflat in south San Francisco Bay-April 1990-April 1991: U.S. Geological Survey Open-File Report 91-460, 47 p., https://doi.org/10.3133/ofr91460.

Luoma, S.N., Cain, D.J., Brown, C., Hornberger, M., and Bouse, R., 1996, Near field receiving water monitoring of trace metals in clams (Macoma balthica) and sediments near the Palo Alto and San Jose/Sunnyvale Water Quality Control Plants in south San Francisco Bay-December 1994 - December 1995: U.S. Geological Survey Open-File Report 96-203, 90 p., https://doi.org/10.3133/ofr96203.

Luoma, S.N., Cain, D.J., Brown, C.L., Hornberger, M.I., and Bouse-Schaenemann, R.M., 1995a, Near field receiving water monitoring of trace metals in clams (Macoma balthica) and sediments near the Palo Alto and San Jose/ Sunnyvale Water Quality Control Plants in south San Francisco Bay_-June 1993 through October 1994: U.S. Geological Survey Open-File Report 95-299, 83 p., https://doi.org/10.3133/ofr95299.

Luoma, S.N., Cain, D., and Johansson, C., 1985, Temporal fluctuations of silver, copper and zinc in the bivalve Macoma balthica at five stations in south San Francisco Bay: Hydrobiologia, v. 129, p. 109-120, https://doi.org/ 10.1007/BF00048690.

Luoma, S.N., and Cloern, J.E., 1982, The impact of wastewater discharge on biological communities in San Francisco Bay, in Conomos, T.J., ed., San Francisco Bay-The urbanized estuary: San Francisco, Calif., American Association for the Advancement of Science, p. 137-160.
Luoma, S.N., Ho, Y.B., and Bryan, G.W., 1995b, Fate, bioavailability and toxicity of silver in estuarine environments: Marine Pollution Bulletin, v. 31, p. 44-54, https://doi.org/10.1016/0025-326X(95)00081-W.

Moon, E., Shouse, M.K., Parchaso, F., Thompson, J.K., Luoma, S.N., Cain, D.J., and Hornberger, M.I., 2005, Near-field receiving water monitoring of trace metals and a benthic community near the Palo Alto Regional Water Quality Control Plant in south San Francisco Bay, California-2004: U.S. Geological Survey OpenFile Report 2005-1279, 118 p., https://doi.org/10.3133/ ofr20051279.

Morrisey, D.J., Underwood, A.J., and Howitt, L., 1996, Effects of copper on the faunas of marine soft-sedimentsAn experimental field study: Marine Biology, v. 125, p. 199-213, https://doi.org/10.1007/BF00350774.

Newman, M.C., 1998, Fundamentals of ecotoxicology: Chelsea, Mich., Sleeping Bear Press, 402 p.

Nichols, F.N., and Thompson, J.K., 1985a, Persistence of an introduced mudflat community in south San Francisco Bay, California: Marine Ecology Progress Series, v. 24, p. 83-97, https://doi.org/10.3354/meps024083.

Nichols, F.N., and Thompson, J.K., 1985b, Time scales of change in the San Francisco Bay benthos: Hydrobiologia, v. 129, p. 121-138, https://doi.org/10.1007/BF00048691.

Parchaso, F., 1993, Seasonal reproduction of Potamocorbula amurensis in San Francisco Bay, California: San Francisco, Calif., San Francisco State University, M.S. thesis, 79 p.

Phillips, D.J.H., and Rainbow, P.S., 1993, Biomonitoring of trace aquatic contaminants: Barking, England, Elsevier Science Publishers, LTD, 371 p.

Rasmussen, E., 1956, The reproduction and larval development of some polychaetes from the Isefjord, with some faunistic notes: Biologiske Meddelelser, det Kongelige Danske Videnskabernes Selskab, v. 23, no. 1, p. $1-84$.

Rygg, B., 1985, Effect of sediment copper on benthic fauna: Marine Ecology Progress Series, v. 25, p. 83-89, https://doi.org/10.3354/meps025083.

San Francisco Estuary Institute, 1997, RMP, regional monitoring program for trace substances-1996 Annual report: Richmond, Calif., San Francisco Estuary Institute, 349 p.

Shouse, M.K., 2002, The effects of decreasing trace metal concentrations on benthic community structure: San Francisco, Calif., San Francisco State University, M.S. thesis, $177 \mathrm{p}$. 
Shouse, M.K., Parchaso, F., and Thompson, J.K., 2003, Nearfield receiving water monitoring of a benthic community near the Palo Alto Water Quality Control Plant in south San Francisco Bay-February 1974 through December 2002: U.S. Geological Survey Open-File Report 2003-224, 39 p., https://doi.org/10.3133/ofr03224.

Shouse, M.K., Parchaso, F., and Thompson, J.K., 2004, Nearfield receiving water monitoring of benthic community near the Palo Alto Water Quality Control Plant in south San Francisco Bay-February 1974 through December 2003: U.S. Geological Survey Open-File Report 2004-1210, 39 p., https://doi.org/10.3133/ofr20041210.

Simon, T.P., 2002, Biological response signatures: Boca Raton, Florida, CRC Press, 608 p.

Suter, G.W., II, 2001, Applicability of indicator monitoring to ecological risk assessment: Ecological Indicators, v. 1, no, 2, p. 101-112, https://doi.org/10.1016/S1470$160 \mathrm{X}(01) 00011-5$.

Thompson, J.K., and Parchaso, F., 2012, Benthic invertebrate community assessment as a phytoplankton consumer and fish and bird prey source before and after the start of the restoration: South Bay Salt Pond Restoration Project Cooperative Agreement 2009-0211, 90 p.

Thompson, J.K., Parchaso, F., and Shouse, M.K., 2002, Near field receiving water monitoring of benthic community near the Palo Alto Water Quality Control Plant in south San Francisco Bay-February 1974 through December 2000: U.S. Geological Survey Open-File Report 02-394, 117 p., https://doi.org/10.3133/ofr02394.

Thomson, E.A., Luoma, S.N., Johansson, C.E., and Cain, D.J., 1984, Comparison of sediments and organisms in identifying sources of biologically available trace metal contamination: Water Research, v. 18, no. 6, p. 755-765, https://doi.org/10.1016/0043-1354(84)90172-6.
Thomson-Becker, E.A., and Luoma, S.N., 1985, Temporal fluctuations in grain size, organic materials and iron concentrations in intertidal surface sediment of San Francisco Bay: Hydrobiologia, v. 129, p. 91-107, https://doi.org/10.1007/BF00048689.

Topping, B.R., and Kuwabara, J.S., 2003, Dissolved nickel and benthic flux in south San Francisco Bay-A potential for natural sources to dominate: Bulletin of Environmental Contamination and Toxicology, v. 71, p. 46-51.

U.S. Environmental Protection Agency, 2002, Method 1631, Revision E-Mercury in water by oxidation, purge and trap, and cold vapor atomic fluorescence spectrometry: Washington, D.C., U.S. Environmental Protection Agency EPA-821-R-02-019, 38 p.

U.S. Environmental Protection Agency, 2004, Revised assessment of detection and quantitation approaches: Washington, D.C., U.S. Environmental Protection Agency EPA-821-B-04-005, $254 \mathrm{p}$.

van Geen, A., and Luoma, S.N., 1999, The impact of human activities on sediments of San Francisco Bay, CaliforniaAn overview: Marine Chemistry, v. 64, nos. 1-2, p. 1-6, , https://doi.org/10.1016/S0304-4203(98)00080-2.

Wang, W.-X., and Fisher, N.S., 1999, Delineating metal accumulation pathways for marine invertebrates: Science of The Total Environment, v. 237-238, p. 459-472.

Weesner, F.M., 1960, General zoological microtechniques: Baltimore, Md., Williams \& Wilkins, 230 p.

Whittaker, R.H., 1965, Dominance and diversity in land plant communities: Science, v. 147 , no. 3655, p. 250-260, https://doi.org/10.1126/science.147.3655.250.

World Register of Marine Species, 2020, WoRMS Taxon Match: World Register of Marine Species database, accessed December 29, 2020, at https://doi.org/ $10.14284 / 170$. 


\section{Appendixes 1-9}

The following appendixes contain data that support the study for monitoring trace metals and the benthic community near the Palo Alto Regional Water Quality Control Plant in south San Francisco Bay, Calif. This report includes the data collected by the U.S. Geological Survey for the period January 2019 to December 2019. Selected data also are provided in the data release (Cain and others, 2021) associated with this report. 


\section{Appendix 1. Certified Concentrations and Recovery Percentages of Inorganic Elements in National Institute of Science and Technology Standard Reference Materials 2709a and 2711a, Prepared in 2019}

\begin{tabular}{|c|c|c|c|c|}
\hline \multicolumn{5}{|c|}{$\begin{array}{l}\text { Table 1.1. Certified concentrations and recovery percentages of inorganic elements in National Institute of } \\
\text { Science and Technology standard reference materials 2709a (San Joaquin Soil) and 2711a (Montana II Soil), } \\
\text { prepared in } 2019 . \\
\text { [Standard reference materials issued by National Institute of Science and Technology (https://www.nst.gov). Elements: Ag, silver; } \\
\text { Al, Aluminum; Cr, chromium; Cu, copper; Fe, iron; Ni, nickel; } \mathrm{Zn} \text {, zinc. Other abbreviations: conf. int., 95\% confidence interval; } \\
\text { mg/kg, milligram per kilogram; na, not applicable; nc, not certified; \%, percent] }\end{array}$} \\
\hline Reference material & Element & Sample size & $\begin{array}{c}\text { Certified concentration } \\
\text { value }(\mathrm{mg} / \mathrm{kg})\end{array}$ & $\begin{array}{c}\text { Recovery mean } \\
\pm \text { conf. int. }(\%)\end{array}$ \\
\hline \multirow[t]{7}{*}{ 2709a (San Joaquin soil) } & $\mathrm{Al}$ & 17 & 73,700 & $37 \pm 3$ \\
\hline & $\mathrm{Cr}$ & 17 & 130 & $63 \pm 3$ \\
\hline & $\mathrm{Cu}$ & 17 & 33.9 & $76 \pm 2$ \\
\hline & $\mathrm{Fe}$ & 17 & 33,600 & $87 \pm 2$ \\
\hline & $\mathrm{Ni}$ & 17 & 85 & $88 \pm 1$ \\
\hline & $\mathrm{Ag}$ & na & $\mathrm{nc}$ & na \\
\hline & $\mathrm{Zn}$ & 17 & 103 & $87 \pm 1$ \\
\hline \multirow[t]{7}{*}{ 2711a (Montana II soil) } & $\mathrm{Al}$ & 18 & 67,200 & $32 \pm 1$ \\
\hline & $\mathrm{Cr}$ & 18 & 52.3 & $47 \pm 3$ \\
\hline & $\mathrm{Cu}$ & 18 & 140 & $90 \pm 1$ \\
\hline & $\mathrm{Fe}$ & 18 & 28,200 & $78 \pm 1$ \\
\hline & $\mathrm{Ni}$ & 18 & 21.7 & $80 \pm 9$ \\
\hline & $\mathrm{Ag}$ & 18 & 6 & $85 \pm 2$ \\
\hline & $\mathrm{Zn}$ & 18 & 414 & $92 \pm 1$ \\
\hline
\end{tabular}




\section{Appendix 2. Certified Concentrations and Recovery Percentages of Inorganic Elements in National Research Council Canada Certified Reference Material TORT-3 and National Institute of Science and Technology Standard Reference Material 1566b, Prepared in 2019}

Table 2.1. Certified concentrations and recovery percentages of inorganic elements in National Research Council Canada certified reference material TORT-3 (lobster Hepatopancreas) and National Institute of Science and Technology standard reference material 1566b (oyster tissue), prepared in 2019.

[Sources of reference materials: TORT-3 (lobster hepatopancreas), National Research Council Canada (https://nrc.canada.ca); 1566b (oyster tissue), National Institute of Science and Technology (https://www.nst.gov). Samples were not diluted prior to analysis. Elements: Ag, silver; Cr, chromium; Cu, copper; Ni, nickel; $\mathrm{Zn}$, zinc. Other abbreviations: conf. int., $95 \%$ confidence interval; mg/kg, milligram per kilogram; na, not applicable; nc, not certified; \%, percent]

\begin{tabular}{ccccc}
\hline Reference material & Element & Sample size & $\begin{array}{c}\text { Certified concentration } \\
\text { value (mg/kg) }\end{array}$ & $\begin{array}{c}\text { Recovery mean } \\
\mathbf{\pm c o n f} \text { int. (\%) }\end{array}$ \\
\hline $\begin{array}{c}\text { TORT-3 (lobster } \\
\text { hepatopancreas) }\end{array}$ & $\mathrm{Cr}$ & 18 & 1.95 & $87 \pm 3$ \\
& $\mathrm{Cu}$ & 18 & 497 & $94 \pm 1$ \\
& $\mathrm{Ni}$ & 18 & 5.3 & $85 \pm 1$ \\
& $\mathrm{Ag}$ & $\mathrm{na}$ & $\mathrm{nc}$ & $\mathrm{na}$ \\
& $\mathrm{Zn}$ & 18 & 136 & $98 \pm 1$ \\
& $\mathrm{Cr}$ & 18 & $\mathrm{nc}$ & $\mathrm{na}$ \\
& $\mathrm{Cu}$ & $\mathrm{na}$ & 71.6 & $98 \pm 2$ \\
& $\mathrm{Ni}$ & 18 & 1.04 & $88 \pm 6$ \\
& $\mathrm{Ag}$ & 18 & 0.666 & $86 \pm 5$ \\
& $\mathrm{Zn}$ & 18 & 1,424 & $103 \pm 2$ \\
\hline
\end{tabular}




\section{Appendix 3. Mercury and Selenium Concentrations Determined in Sample Splits of Surface Sediments and Clam Limecola petalum Collected at Palo Alto, Calif., Site in 2019}

Table 3.1. Mercury $(\mathrm{Hg})$ and selenium (Se) concentrations determined in sample splits of surface sediments and clam Limecola petalum collected at Palo Alto, Calif., site in 2019.

[One sediment sample and one clam tissue sample were split and analyzed for selenium (Se) and mercury (Hg); split results are shown here. Absolute deviation $=$ difference between replicates $\div 2$. Other abbreviations: $\mathrm{CV}$, coefficient of variation $[=($ absolute deviation $\div \operatorname{mean}) \times 100] ; \mathrm{mg} / \mathrm{kg}, \mathrm{milligram}$ per kilogram dry weight; na, not applicable; \%, percent]

\begin{tabular}{|c|c|c|c|c|c|c|}
\hline Sample type & Element & Sample & $\begin{array}{c}\text { Measured } \\
\text { concentration } \\
(\mathrm{mg} / \mathrm{kg})\end{array}$ & Mean & $\begin{array}{l}\text { Absolute } \\
\text { deviation }\end{array}$ & $\begin{array}{l}\text { CV } \\
(\%)\end{array}$ \\
\hline \multirow[t]{4}{*}{ Sediment } & $\mathrm{Hg}$ & 20190412_SeM_PAMF_SD_32 & 0.28 & 0.28 & 0.002 & 0.70 \\
\hline & & 20190412_SeM_PAMF_SD_32 LDUP & 0.28 & na & na & na \\
\hline & $\mathrm{Se}$ & 20191220_SeM_PAMF_SD_1 & 0.32 & 0.31 & 0.005 & 1.56 \\
\hline & & 20191220_SeM_PAMF_SD_1 Dup & 0.31 & na & na & na \\
\hline \multirow[t]{6}{*}{ Clam tissue } & $\mathrm{Hg}$ & 20190226_SeM_PAMF_MPE_2 & 0.49 & 0.49 & 0.003 & 0.56 \\
\hline & & 20190226_SeM_PAMF_MPE_2 LDUP & 0.49 & na & na & na \\
\hline & & 20190619_SeM_PAMF_MPE_1 & 0.39 & 0.39 & 0.004 & 0.92 \\
\hline & & 20190619_SeM_PAMF_MPE_1 LDUP & 0.39 & na & na & na \\
\hline & $\mathrm{Se}$ & 20190619 SeM PAMF MPE 1 & 3.67 & 3.70 & 0.025 & 0.69 \\
\hline & & 20190619 SeM PAMF MPE 1 Dup & 3.72 & na & na & na \\
\hline
\end{tabular}




\section{Appendix 4. Recovery Percentages ( \pm Standard Deviation) of Mercury and Selenium in Standard Reference Materials}

Table 4.1. Recovery percentages ( \pm standard deviation) of mercury $(\mathrm{Hg})$ and selenium $(\mathrm{Se})$ in standard reference materials.

[Sources of reference materials: NIST 2976, National Institute of Science and Technology (https://www.nst.gov); TORT-3, PACS-3, DOLT-3, MESS, National Research Council Canada (https://nrc.canada.ca); Abbreviations: mg/kg, milligram per kilogram; SD, standard deviation; \%, percent]

\begin{tabular}{llcccc}
\hline Reference material & Category of material & Element & Sample size & $\begin{array}{c}\text { Certified } \\
\text { concentration } \\
(\mathbf{m g} / \mathbf{k g})\end{array}$ & $\begin{array}{c}\text { Recovery mean } \\
\mathbf{\pm S D}(\%)\end{array}$ \\
\hline TORT-3 & Biological tissue & $\mathrm{Hg}$ & 2 & 0.29 & $90 \pm 2$ \\
NIST 2976 & Biological tissue & $\mathrm{Hg}$ & 2 & 0.06 & $118 \pm 5$ \\
& & $\mathrm{Se}$ & 3 & 1.8 & $104 \pm 10$ \\
PACS-3 & Sediment & $\mathrm{Hg}$ & 2 & 2.98 & $89 \pm 3$ \\
DOLT-3 & Biological tissue & $\mathrm{Se}$ & 3 & 7.1 & $100 \pm 6$ \\
MESS & Sediment & $\mathrm{Se}$ & 3 & 0.72 & $108 \pm 2$ \\
\hline
\end{tabular}




\section{Appendix 5. Method Detection Limits and Method Reporting Levels for Inductively Coupled Plasma Optical Emission Spectrophotometry Methods}

Table 5.1. Method detection limits and method reporting levels for inductively coupled plasma optical emission spectrophotometry methods.

[Concentrations are reported as milligrams per liter (mg/L). Elements: Ag, silver; Al, Aluminum; Cr, chromium; Cu, copper; Fe, iron; Ni, nickel; Zn, zinc. Other abbreviations: MDL, method detection limit; MRL, method reporting level; nd, not determined]

\begin{tabular}{rllllllll}
\hline \multicolumn{1}{c}{ Method } & Method limit & Ag & Al & Cr & Cu & Fe & Ni & Zn \\
\hline \multirow{2}{*}{ Sediment } & MDL & 0.0005 & 0.0059 & 0.0023 & 0.0023 & 0.0022 & 0.0006 & 0.0005 \\
& MRL & 0.001 & 0.0118 & 0.0047 & 0.0046 & 0.0043 & 0.0011 & 0.001 \\
\multirow{2}{*}{ Tissue } & MDL & 0.0004 & nd & 0.0013 & 0.0023 & nd & 0.0003 & 0.0006 \\
& MRL & 0.0008 & nd & 0.0026 & 0.0046 & nd & 0.0006 & 0.0012 \\
\hline
\end{tabular}




\section{Appendix 6. Statistical Summary of Silver and Copper Concentrations in Sediment and Clam Limecola petalum Collected at Palo Alto, Calif., Site in 2019 and in 1977-2019}

Table 6.1. Statistical summary of silver $(\mathrm{Ag})$ and copper $(\mathrm{Cu})$ concentrations in sediment and clam Limecola petalum collected at Palo Alto, Calif., site in 2019 and in 1977-2019.

[Units for soft tissue of clam (Limecola petalum) and for sediment are milligrams per kilogram dry weight. Data in 2019 column is annual (grand) mean for calendar year; other columns are statistics for annual (grand) means of 1977-2019. Samples for each year were collected between January and December of that year]

\begin{tabular}{cllccccc}
\hline \multicolumn{1}{c}{ Sample type } & Element & \multicolumn{1}{c}{ Method } & $\mathbf{2 0 1 9}$ & Mean & Median & Minimum & Maximum \\
\hline Sediment & $\mathrm{Ag}$ & Partial extraction & 0.20 & 0.50 & 0.35 & 0.20 & 1.62 \\
& $\mathrm{Cu}$ & Partial extraction & 16.1 & 22.2 & 18.5 & 12.4 & 55.3 \\
& $\mathrm{Cu}$ & Near total & 28.0 & 45.1 & 43.9 & 28.0 & 85.9 \\
\multirow{5}{*}{ Clam tissue } & $\mathrm{Ag}$ & Tissue digest & 4 & 22 & 4 & 2 & 113 \\
& $\mathrm{Cu}$ & Tissue digest & 62 & 79 & 45 & 24 & 283 \\
\hline
\end{tabular}




\section{Appendix 7. Reproduction Data for Clam Limecola petalum Collected at Palo Alto, Calif., Site in 2015-2019}

Table 7.1. Reproduction data for clam Limecola petalum collected at Palo Alto, Calif., site in 2015-2019.

[Data are percentages of clams in each stage of reproduction. Spent means clams have released all their gametes. Reproductive is sum of percentages of active, ripe, and spawning stages; nonreproductive is sum of percentage of inactive and spent stages. Abbreviations: No., number of clams analyzed; nd, no data]

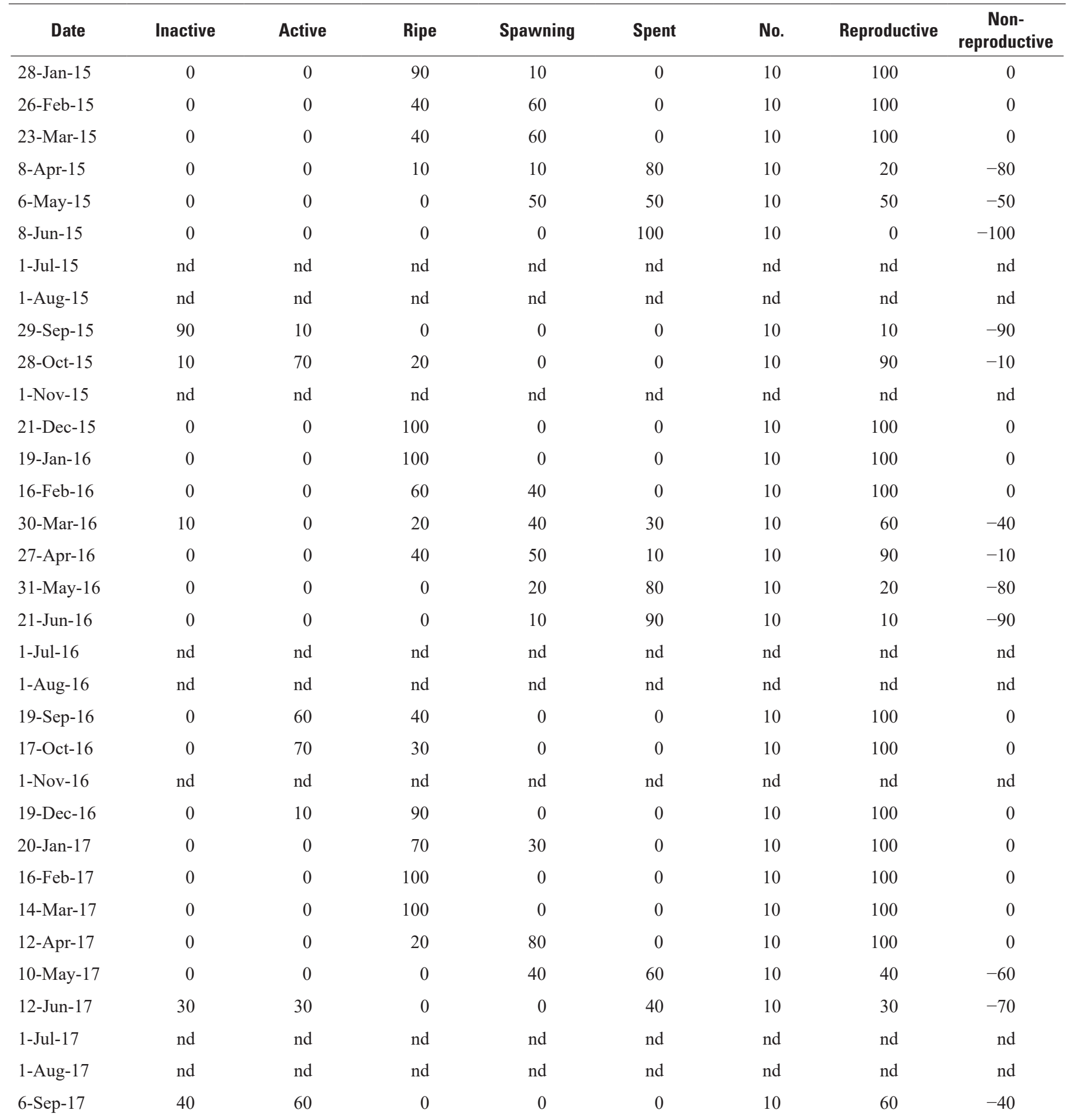


Table 7.1. Reproduction data for clam Limecola petalum collected at Palo Alto, Calif., site in 2015-2019.—Continued

[Data are percentages of clams in each stage of reproduction. Spent means clams have released all their gametes. Reproductive is sum of percentages of active, ripe, and spawning stages; nonreproductive is sum of percentage of inactive and spent stages. Abbreviations: No., number of clams analyzed; nd, no data]

\begin{tabular}{|c|c|c|c|c|c|c|c|c|}
\hline Date & Inactive & Active & Ripe & Spawning & Spent & No. & Reproductive & $\begin{array}{c}\text { Non- } \\
\text { reproductive }\end{array}$ \\
\hline 18-Oct-17 & 0 & 30 & 60 & 10 & 0 & 10 & 100 & 0 \\
\hline 1-Nov-17 & nd & nd & nd & nd & nd & nd & nd & nd \\
\hline 11-Dec-17 & 0 & 33.3 & 55.6 & 11.1 & 0 & 9 & 100 & 0 \\
\hline 9-Jan-18 & 0 & 0 & 90 & 10 & 0 & 10 & 100 & 0 \\
\hline 20-Feb-18 & 0 & 20 & 50 & 30 & 0 & 10 & 100 & 0 \\
\hline 21-Mar-18 & 0 & 0 & 80 & 20 & 0 & 10 & 100 & 0 \\
\hline 24-Apr-18 & 0 & 0 & 30 & 50 & 20 & 10 & 80 & -20 \\
\hline 22-May-18 & 0 & 0 & 10 & 10 & 80 & 10 & 20 & -80 \\
\hline 19-Jun-18 & 30 & 70 & 0 & 0 & 0 & 10 & 70 & -30 \\
\hline 1-Jul-18 & nd & nd & nd & nd & nd & nd & nd & nd \\
\hline 1-Aug-18 & nd & nd & nd & nd & nd & nd & nd & nd \\
\hline 12-Sep-18 & 40 & 50 & 10 & 0 & 0 & 10 & 60 & -40 \\
\hline 10 -Oct-18 & 0 & 80 & 20 & 0 & 0 & 10 & 100 & 0 \\
\hline 1-Nov-18 & nd & nd & nd & nd & nd & nd & nd & nd \\
\hline 17-Dec-18 & 0 & 0 & 100 & 0 & 0 & 10 & 100 & 0 \\
\hline 19-Jan-19 & 0 & 0 & 100 & 0 & 0 & 10 & 100 & 0 \\
\hline 25-Feb-19 & 0 & 0 & 0 & 80 & 20 & 10 & 80 & -20 \\
\hline 25-Mar-19 & 0 & 0 & 90 & 10 & 0 & 10 & 100 & 0 \\
\hline 24-Apr-19 & 0 & 0 & 0 & 80 & 20 & 10 & 80 & -20 \\
\hline 20-Мау-19 & 0 & 0 & 0 & 40 & 60 & 10 & 40 & -60 \\
\hline 19-Jun-19 & 0 & 0 & 0 & 0 & 100 & 10 & 0 & -100 \\
\hline 1-Jul-19 & nd & nd & nd & nd & nd & nd & nd & nd \\
\hline 1-Aug-19 & nd & nd & nd & nd & nd & nd & nd & nd \\
\hline 17-Sep-19 & 44.4 & 55.6 & 0 & 0 & 0 & 9 & 55.6 & -44.4 \\
\hline 28-Oct-19 & 0 & 90 & 10 & 0 & 0 & 10 & 100 & 0 \\
\hline 1-Nov-19 & nd & nd & nd & nd & nd & nd & nd & nd \\
\hline 20-Dec-19 & 30 & 40 & 30 & 0 & 0 & 10 & 70 & -30 \\
\hline
\end{tabular}




\section{Appendix 8. Complete List of Benthic Species Found at Palo Alto, Calif., Site in 2019}




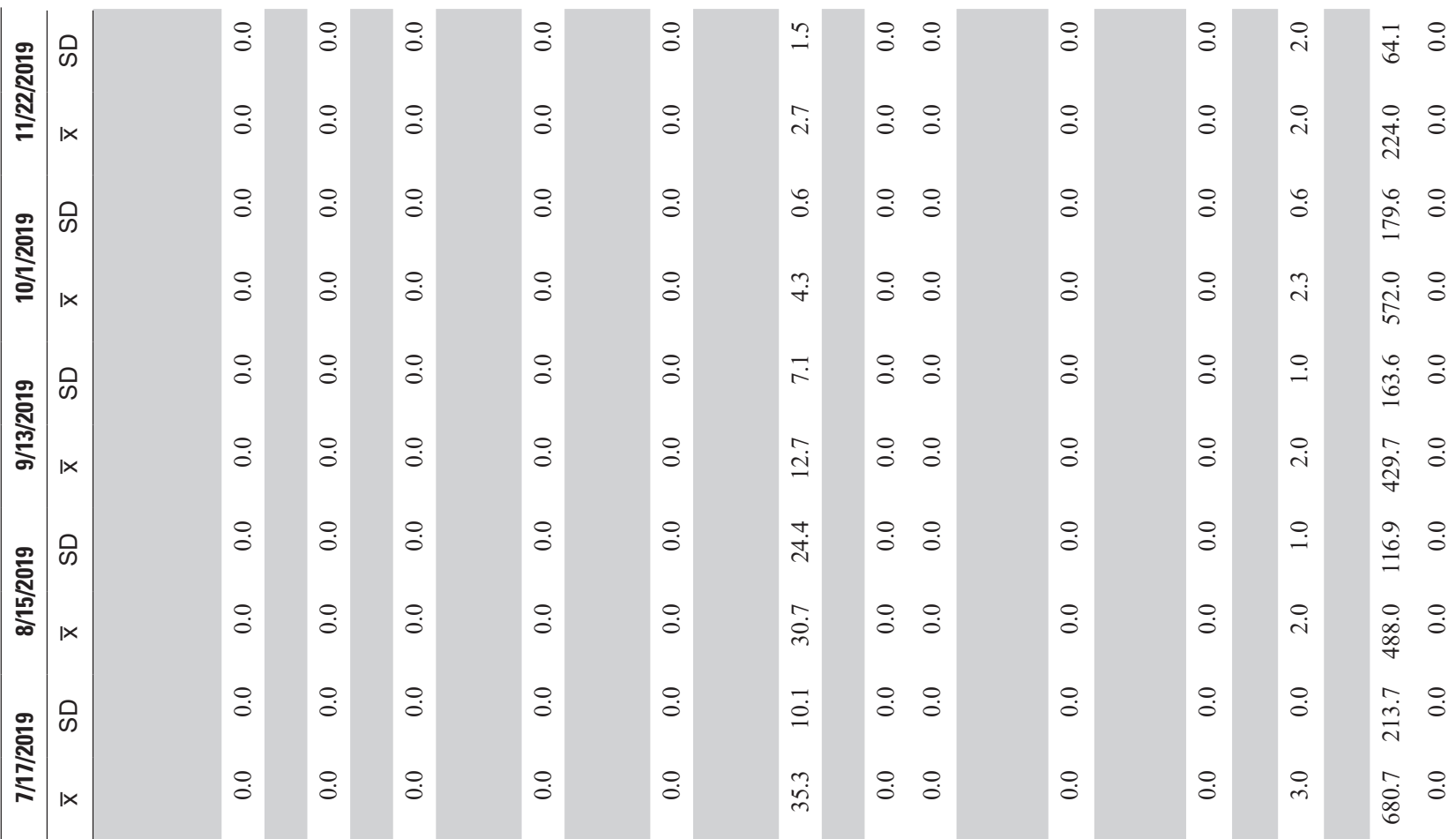

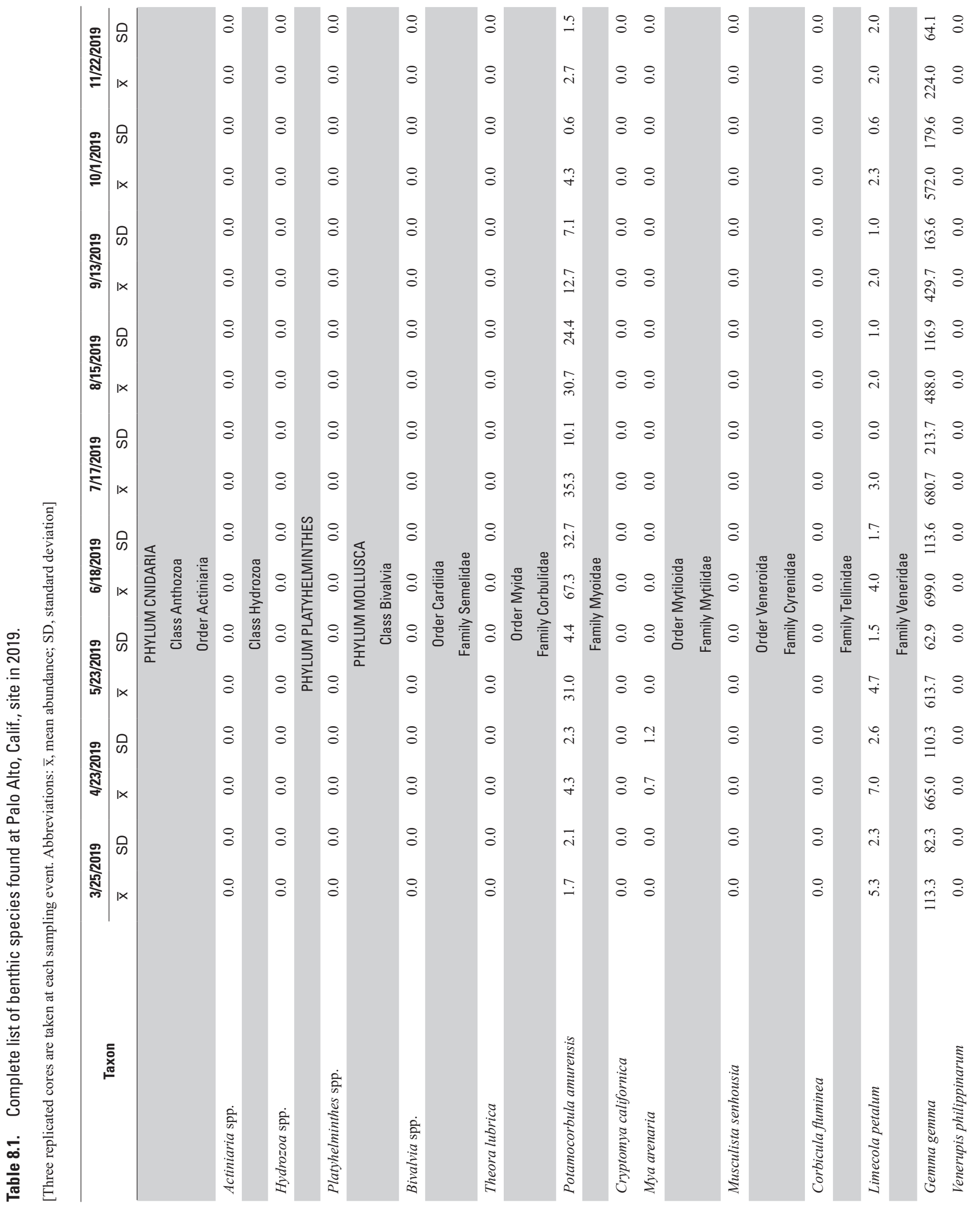




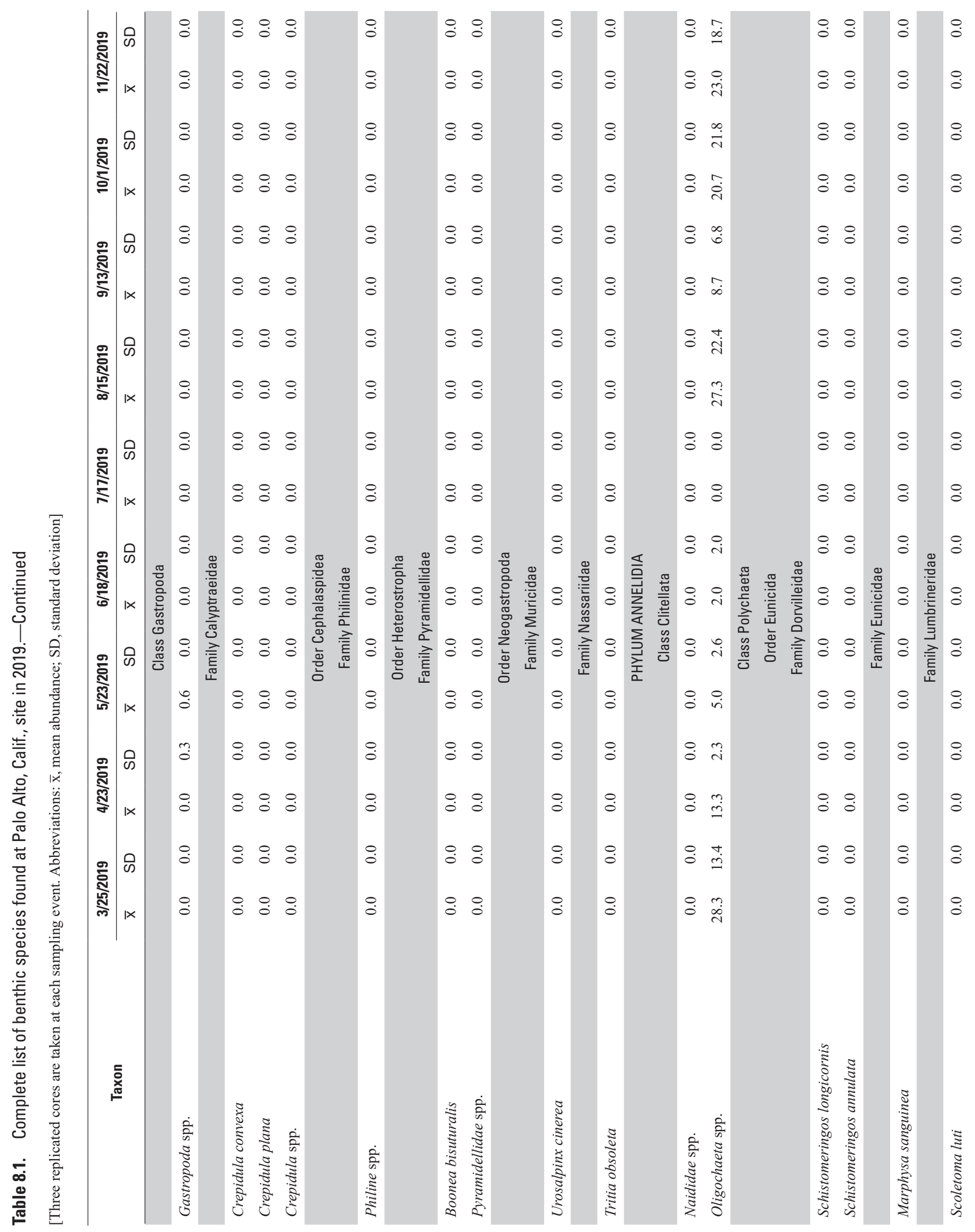




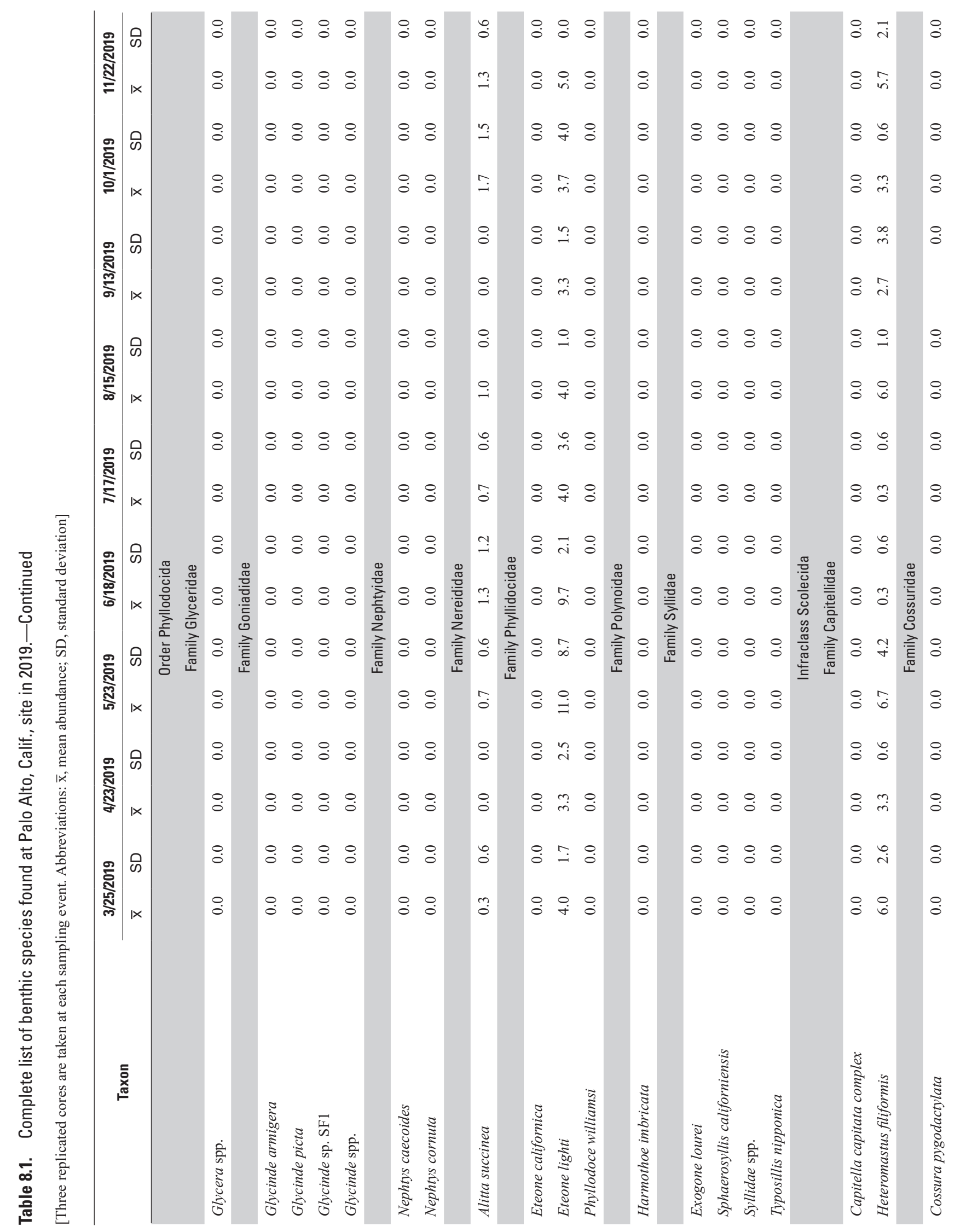




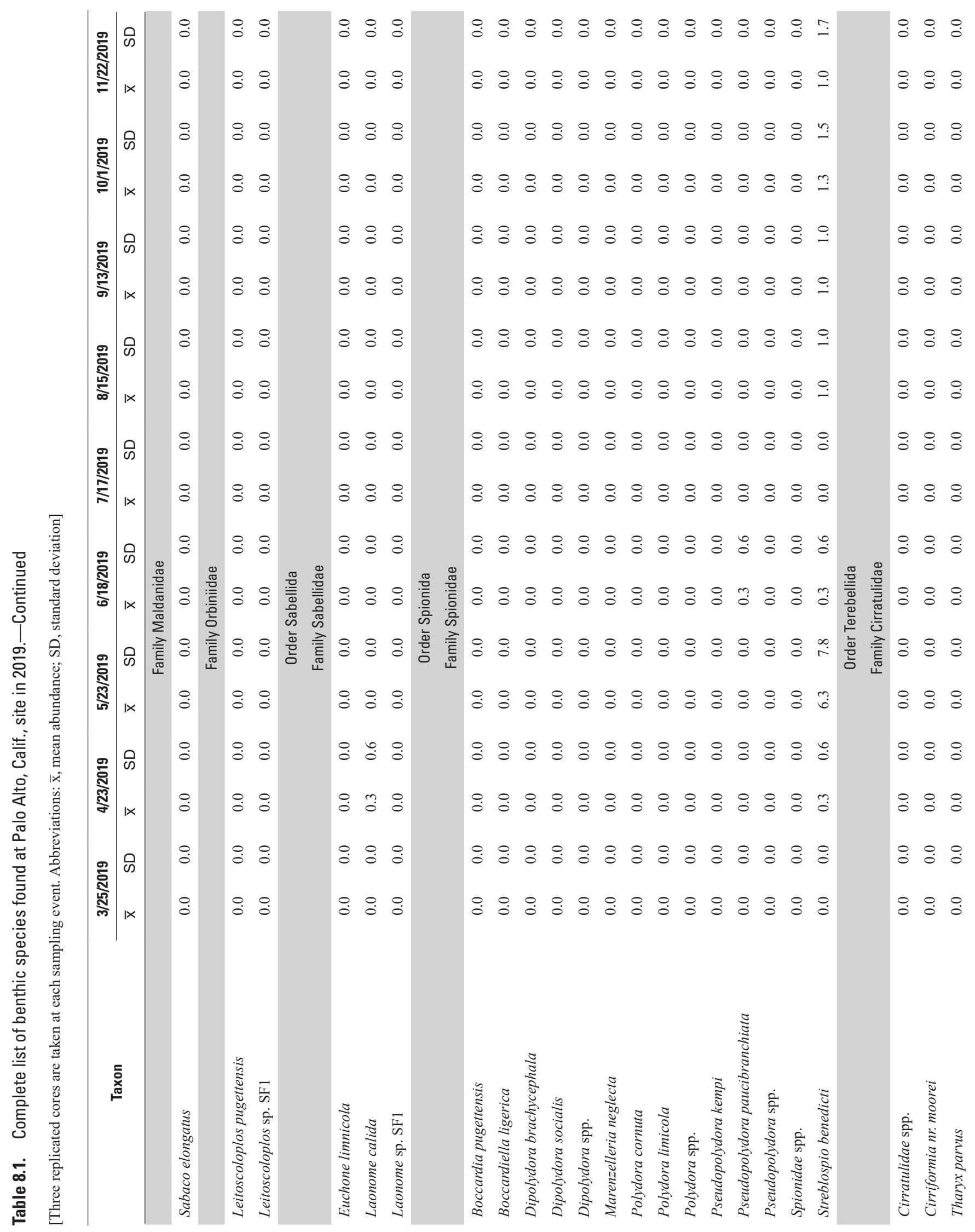




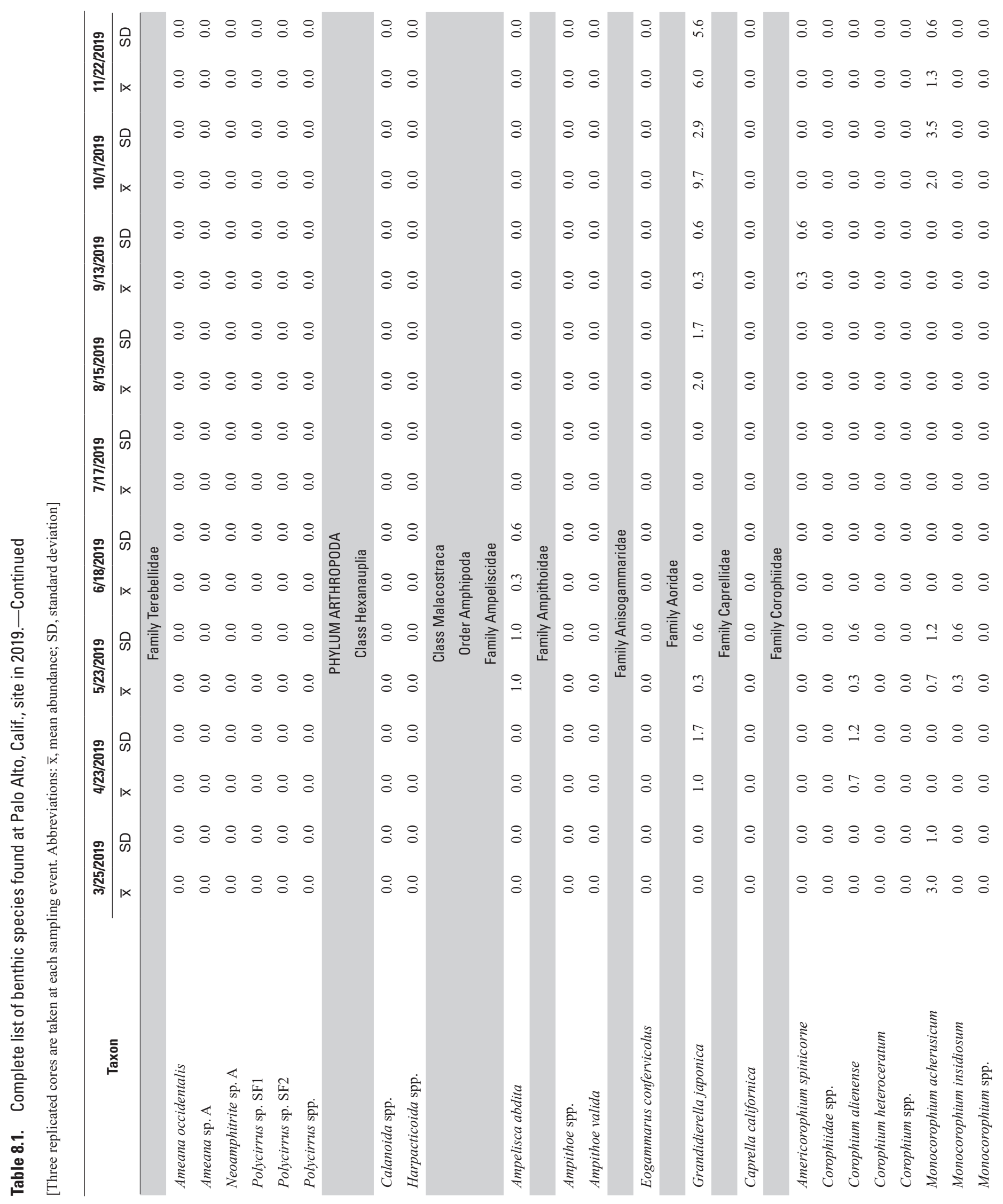




\begin{tabular}{|c|c|c|c|c|c|c|c|c|c|c|c|c|}
\hline क & $\therefore$ & $\therefore$ & $\stackrel{8}{8}$ & $\therefore:$ & $\stackrel{n}{\check{n}}$ & $\stackrel{8}{\circ}$ & $\therefore$ & 8 & 8 & $\stackrel{8}{8}$ & $\stackrel{8}{\circ}$ & 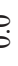 \\
\hline $\mid x$ & $\stackrel{8}{8}$ & : & $\stackrel{8}{\circ}$ & $\stackrel{8}{8}$ & $\stackrel{9}{g}$ & $\because$ & $\stackrel{8}{\circ}$ & $\stackrel{8}{8}$ & 8 & a & $\stackrel{8}{8}$ & : \\
\hline के & & & $\circ$ & $\therefore:$ & $\stackrel{n}{n}$ & $\stackrel{0}{\circ}$ & $\stackrel{8}{\circ}$ & $\stackrel{8}{\circ}$ & 8 & 8 & & : \\
\hline$x$ & & : & $\stackrel{8}{\circ}$ & $: 8$ & 。. & $\stackrel{8}{\circ}$ & $\stackrel{8}{\circ}$ & $\stackrel{\circ}{\circ}$ & : & 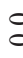 & 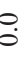 & : \\
\hline के & & $\stackrel{8}{8}$ & $\stackrel{8}{\circ}$ & $\because 8$ & $\stackrel{m}{=}$ & $\because$ & $\stackrel{8}{8}$ & $\stackrel{8}{\circ}$ & $\stackrel{8}{8}$ & a & 8 & 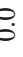 \\
\hline$x$ & & $\stackrel{8}{\circ}$ & $\stackrel{8}{\circ}$ & $\therefore:$ & :ें & $\stackrel{8}{\circ}$ & $\therefore$ & $\stackrel{\circ}{\circ}$ & $\stackrel{8}{8}$ & 8 & 8 & 8 \\
\hline के & & $\stackrel{8}{8}$ & $\stackrel{8}{8}$ & $\therefore 8$ & $\stackrel{m}{2}$ & $\therefore$ & $\stackrel{8}{8}$ & $\stackrel{\circ}{\circ}$ & $\stackrel{8}{8}$ & $a$ & 8 & 8 \\
\hline |x & & $\stackrel{P}{s}$ & $\stackrel{8}{\circ}$ & $\therefore:$ & $\vec{d}$ & $\because$ & $\stackrel{8}{8}$ & $\stackrel{8}{8}$ & $\stackrel{8}{8}$ & a & : & : \\
\hline के & & 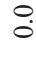 & $\stackrel{8}{\circ}$ & $: 8$ & $\overrightarrow{0}$ & $\stackrel{\circ}{\circ}$ & 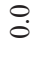 & $\stackrel{8}{\circ}$ & 8 & a & 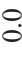 & 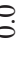 \\
\hline $\mid x$ & 0 & 0 & $\stackrel{8}{8}$ & $\stackrel{\circ}{\circ}$ & ì & $\stackrel{8}{\circ}$ & 0 & 0 & 0 & $a$ & $\stackrel{8}{\circ}$ & 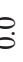 \\
\hline
\end{tabular}

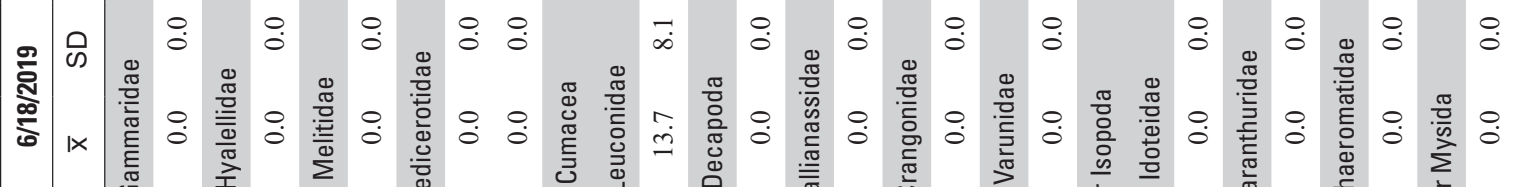

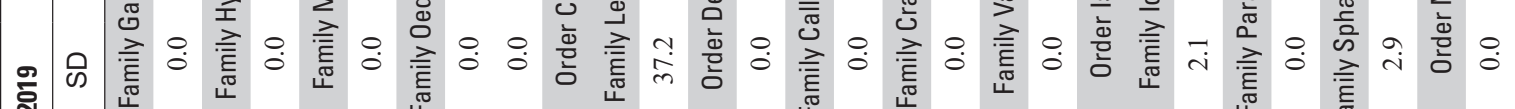

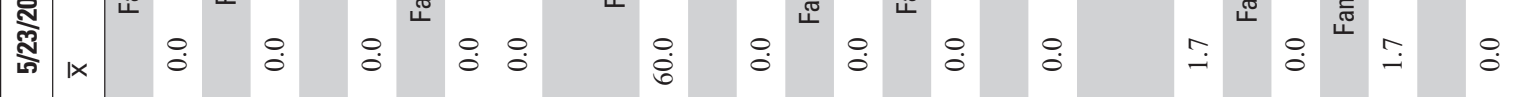

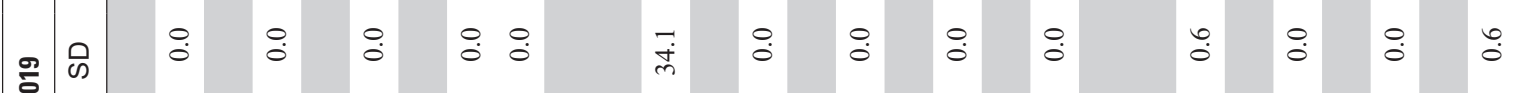

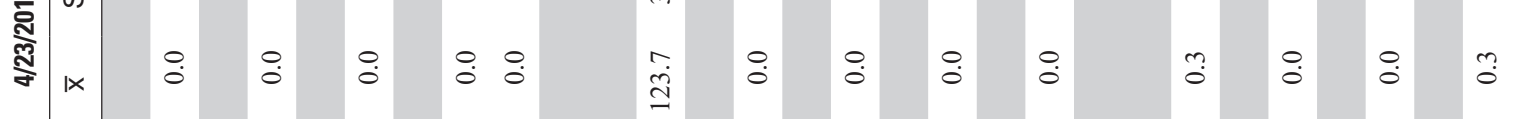

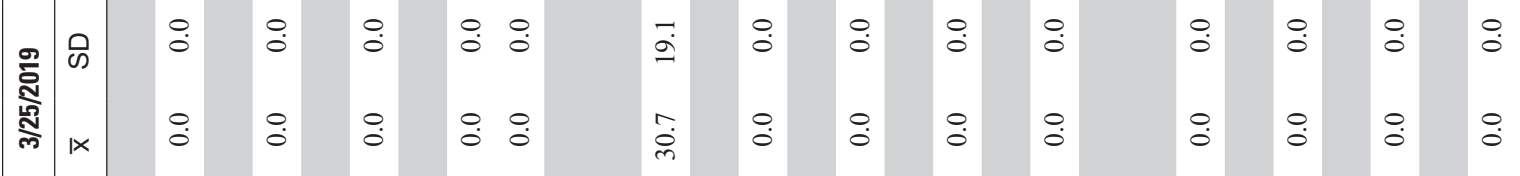




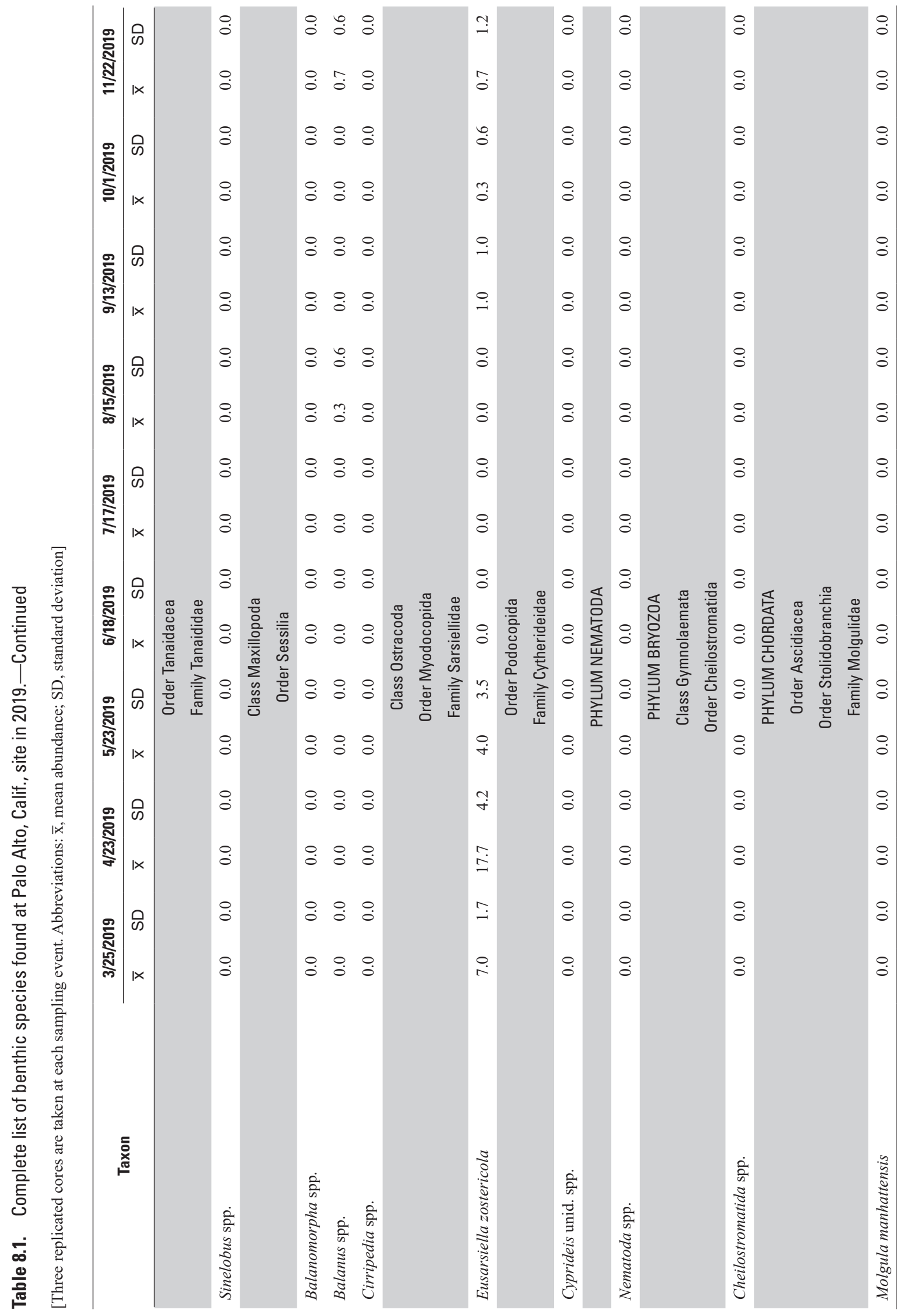




\section{Appendix 9. Benthic Species Name Changes as of 2019}

Table 9.1. Benthic species name changes as of 2019.

[Current species names from World Register of Marine Species (2020)]

\begin{tabular}{|c|c|}
\hline \multirow[t]{4}{*}{ Current species name } & Formerly documented as \\
\hline & PHYLUM CNIDARIA \\
\hline & Class Anthozoa \\
\hline & Order Actiniaria \\
\hline Actiniaria spp. & Anthozoa, unid. Actiniaria, Actiniaria unid. spp. \\
\hline \multicolumn{2}{|r|}{ PHYLUM PLATYHELMINTHES } \\
\hline Platyhelminthes spp. & Turbellaria, Turbellaria unid. spp. \\
\hline \multicolumn{2}{|r|}{ PHYLUM NEMATODA } \\
\hline Nematoda spp. & Nematoda unid. spp. \\
\hline \multicolumn{2}{|r|}{ PHYLUM ANNELIDA } \\
\hline \multicolumn{2}{|r|}{ Class Clitellata } \\
\hline Naididae spp. & Naididae, Naididae unid. spp. \\
\hline Oligochaeta spp. & Oligochaeta, unid. Oligochaeta family, Oligochaeta unid. spp. \\
\hline \multicolumn{2}{|r|}{ Class Polychaeta } \\
\hline Polychaeta spp. & unid. Polychaeta, Polychaeta, Polychaeta unid. spp. \\
\hline \multicolumn{2}{|r|}{ Order Eunicida } \\
\hline \multicolumn{2}{|r|}{ Family Dorvilleidae } \\
\hline Schistomeringos longicornis & Dorvillea longicornis \\
\hline Schistomeringos annulata & Dorvillea annulata, Dorvillea longicornuta, Schistomeringos longicornuta, Dorvillea rudolphi \\
\hline \multicolumn{2}{|r|}{ Order Phyllodocida } \\
\hline \multicolumn{2}{|r|}{ Family Glyceridae } \\
\hline Glycera spp. & Glycera unid. spp. \\
\hline \multicolumn{2}{|r|}{ Family Goniadidae } \\
\hline Glycinde picta & Glycinde polygnatha \\
\hline Glycinde sp. SF1 & Glycinde unid. sp. SF1 \\
\hline Glycinde spp. & Glycinde unid. spp. \\
\hline \multicolumn{2}{|r|}{ Family Nereididae } \\
\hline Alitta succinea & Neanthes succinea \\
\hline \multicolumn{2}{|r|}{ Family Phyllidocidae } \\
\hline Eteone spp. & Eteone? Californica, Eteone unid. spp. \\
\hline \multicolumn{2}{|r|}{ Family Syllidae } \\
\hline Sphaerosyllis unid. sp. A & Sphaerosylis spp. \\
\hline \multicolumn{2}{|r|}{ Infraclass Scolecida } \\
\hline \multicolumn{2}{|r|}{ Family Capitellidae } \\
\hline Capitella capitata complex & Capitella "capitata" \\
\hline \multicolumn{2}{|r|}{ Family Maldanidae } \\
\hline Maldanidae spp. & unid. Maldanidae, Maldanidae unid. spp. \\
\hline \multicolumn{2}{|r|}{ Order Sabellida } \\
\hline \multicolumn{2}{|r|}{ Family Sabellidae } \\
\hline
\end{tabular}


Table 9.1. Benthic species name changes as of 2019.-Continued

[Current species names from World Register of Marine Species (2020)]

\begin{tabular}{|c|c|}
\hline Current species name & Formerly documented as \\
\hline \multicolumn{2}{|r|}{ Order Spionida } \\
\hline \multicolumn{2}{|r|}{ Family Spionidae } \\
\hline Polydora cornuta & Polydora lighti, Polydora ligni \\
\hline Polydora spp. & Polydora unid. spp. \\
\hline Spionidae spp. & unid. Spionidae, Spionidae spp., Spionidae unid. spp. \\
\hline \multicolumn{2}{|r|}{ Order Terebellida } \\
\hline \multicolumn{2}{|r|}{ Family Cirratulidae } \\
\hline Cirratulidae spp. & Tharyx spp. ?, Cirratulidae, Cirratulidae unid. spp. \\
\hline \multicolumn{2}{|r|}{ PHYLUM ARTHROPODA } \\
\hline \multicolumn{2}{|r|}{ Class Insecta } \\
\hline Chironomidae spp. & Chironomidae, Chironomidae unid. spp. \\
\hline \multicolumn{2}{|r|}{ Class Hexanauplia } \\
\hline Calanoida spp. & Calanoida, Calanoida unid. spp. \\
\hline Harpacticoida spp. & Harpacticoida, Harpacticoida unid. spp. \\
\hline \multicolumn{2}{|r|}{ Class Malacostraca } \\
\hline \multicolumn{2}{|r|}{ Order Amphipoda } \\
\hline \multicolumn{2}{|r|}{ Family Ampithoidae } \\
\hline Ampithoe spp. & Ampithoe unid. spp. \\
\hline \multicolumn{2}{|r|}{ Family Anisogammaridae } \\
\hline Eogammarus confervicolus & Anisogammarus confervicolus \\
\hline \multicolumn{2}{|r|}{ Family Corophiidae } \\
\hline Americorophium spinicorne & Corophium spinicorne \\
\hline Corophiidae spp. & Corophium spp., Corophiidae unid. spp. \\
\hline Corophium spp. & Corophiidae unid., Corophium unid. spp. \\
\hline Monocorophium acherusicum & Corophium ascherusicum \\
\hline Monocorophium insidiosum & Corophium insidiosum \\
\hline Monocorophium spp. & $\begin{array}{l}\text { Corophium ?insidiosum, Corophium spp. (female and juvenile), Corophium spp. (male), Monoco- } \\
\text { rophium unid. spp. }\end{array}$ \\
\hline \multicolumn{2}{|r|}{ Family Melitidae } \\
\hline Melita spp. & Melita unid. spp. \\
\hline \multicolumn{2}{|r|}{ Family Oedicerotidae } \\
\hline Americhelidium spp. & Synchelidium spp., Americhelidium unid. spp. \\
\hline \multicolumn{2}{|r|}{ Order Cumacea } \\
\hline \multicolumn{2}{|r|}{ Family Leuconidae } \\
\hline Nippoleucon hinumensis & Hemileucon hinumensis \\
\hline \multicolumn{2}{|r|}{ Order Decapoda } \\
\hline \multicolumn{2}{|r|}{ Family Callianassidae } \\
\hline Callianassidae spp. & Callianassidae, Callianassidae unid., Callianassidae unid. spp. \\
\hline \multicolumn{2}{|r|}{ Order Isopoda } \\
\hline \multicolumn{2}{|r|}{ Family Idoteidae } \\
\hline
\end{tabular}


Table 9.1. Benthic species name changes as of 2019.-Continued

[Current species names from World Register of Marine Species (2020)]

\begin{tabular}{|c|c|}
\hline Current species name & Formerly documented as \\
\hline \multicolumn{2}{|r|}{ Family Sphaeromatidae } \\
\hline Sphaeromatidae spp. & Sphaeromatidae (juv.), Sphaeromatidae unid., Dynamella spp., Sphaeromatidae unid. spp. \\
\hline \multicolumn{2}{|r|}{ Order Mysida } \\
\hline Mysida spp. & Mysidacea, Mysidacea spp., Mysidacea unid. spp. \\
\hline \multicolumn{2}{|r|}{ Order Tanaidacea } \\
\hline \multicolumn{2}{|r|}{ Family Tanaididae } \\
\hline Sinelobus spp. & Sinelobus stanfordi, Tanais spp., Sinelobus unid. spp. \\
\hline \multicolumn{2}{|r|}{ Class Maxillopoda } \\
\hline \multicolumn{2}{|r|}{ Order Sessilia } \\
\hline Balanomorpha spp. & Balanus ?aquila, Balanus spp., unid. Balanomorpha, Balanomorpha unid., Balanomorpha unid. spp. \\
\hline Cirripedia spp. & Cirripedia, Cirripedia unid. spp. \\
\hline \multicolumn{2}{|r|}{ Class 0stracoda } \\
\hline \multicolumn{2}{|r|}{ Order Myodocopida } \\
\hline \multicolumn{2}{|r|}{ Family Sarsiellidae } \\
\hline Eusarsiella zostericola & Sarsiella zostericola \\
\hline \multicolumn{2}{|r|}{ Order Podocopida } \\
\hline \multicolumn{2}{|r|}{ Family Cytherideidae } \\
\hline Cyprideis unid. spp. & Cyprideis spp. \\
\hline \multicolumn{2}{|r|}{ PHYLUM MOLLUSCA } \\
\hline \multicolumn{2}{|r|}{ Class Bivalvia } \\
\hline Bivalvia spp. & Bivalvia unid. spp., unid. Bivalvia \\
\hline \multicolumn{2}{|r|}{ Order Myida } \\
\hline \multicolumn{2}{|r|}{ Family Corbulidae } \\
\hline Potamocorbula amurensis & Corbula amurensis \\
\hline \multicolumn{2}{|r|}{ Order Veneroida } \\
\hline \multicolumn{2}{|r|}{ Family Tellinidae } \\
\hline Limecola petalum & Macoma balthica, Macoma petalum \\
\hline Limecola spp. & Macoma unid. spp., Macoma spp. \\
\hline Tellinidae spp. & Tellinidae unid. spp., Tellinidae \\
\hline \multicolumn{2}{|r|}{ Class Gastropoda } \\
\hline Gastropod unid. sp. B & unid. Gastropoda sp. B \\
\hline \multicolumn{2}{|r|}{ Order Cephalaspidea } \\
\hline \multicolumn{2}{|r|}{ Family Philinidae } \\
\hline Philine spp. & Philine unid. spp. \\
\hline \multicolumn{2}{|r|}{ Order Heterostropha } \\
\hline \multicolumn{2}{|r|}{ Family Pyramidellidae } \\
\hline Boonea bisuturalis & Odetta bisuturalis, Odostomia fetella \\
\hline Pyramidellidae spp. & Odostomia spp., Pyramidellidae, unid Gastropod A, Pyramidellidae unid. spp. \\
\hline \multicolumn{2}{|r|}{ Family Nassariidae } \\
\hline Tritia obsoleta & Nassarius obsolete, Ilyanassa obsoletas \\
\hline
\end{tabular}


Moffett Field Publishing Service Center, California Manuscript approved August 2, 2021

Edited by John Mark Brigham and Taryn A. Lindquist Layout by JoJo Mangano 


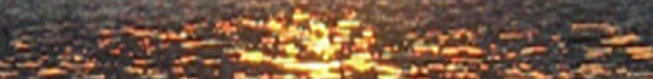

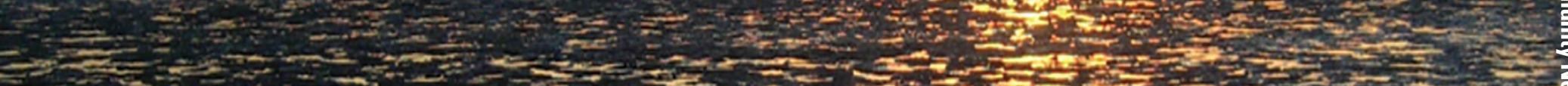

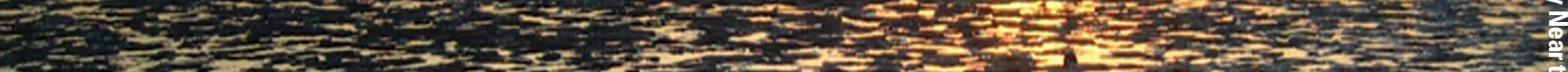

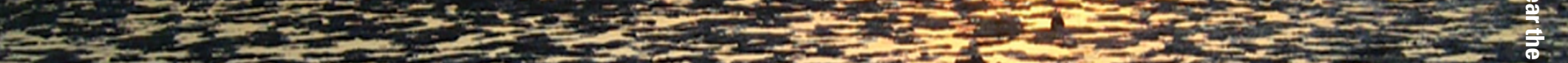

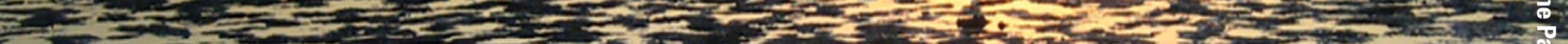

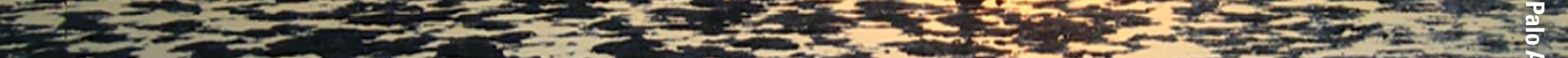

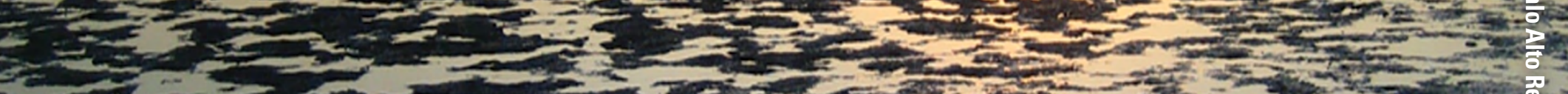

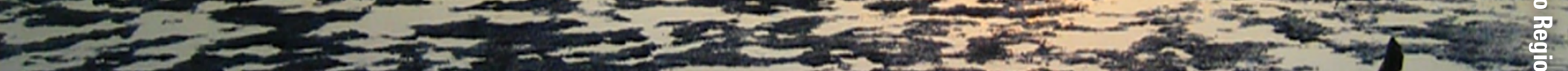

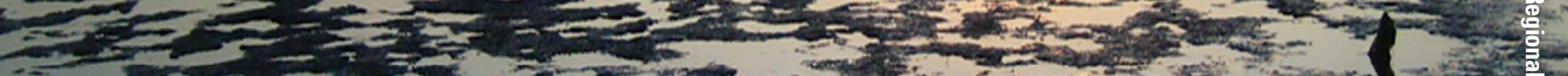

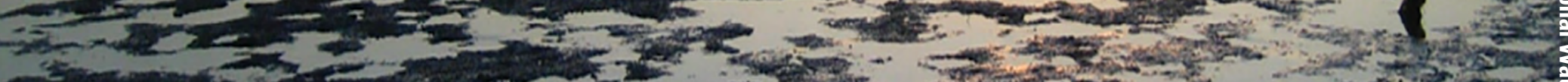

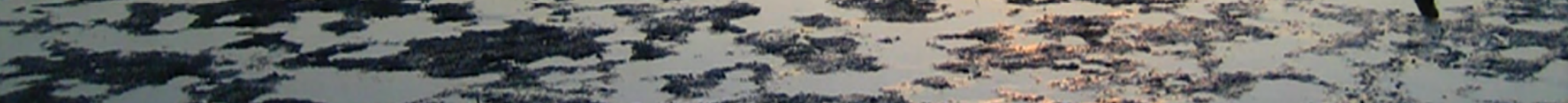

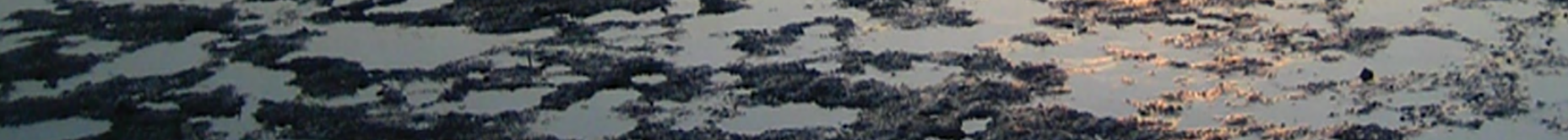

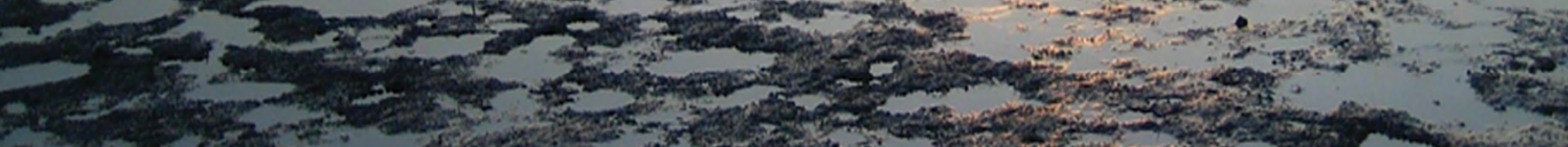

